\title{
OBSERVACIONES SOBRE EL LÉXICO DE LA EDUCACIÓN EN HERÓDOTO Y TUCÍDIDES*
}

\author{
Juan Antonio López Férez \\ Universidad Nacional de Educación a Distancia (UNED), Madrid \\ jalferez@flog.uned.es
}

\begin{abstract}
A la memoria de Alfonso Férez Hernández, mi tío-abuelo materno. Fue mi maestro, tutor, guía y ejemplo durante los cuatro primeros cursos de Bachillerato, preparados sucesivamente a su lado (Albudeite. Murcia) y aprobados, como alumno libre, en el Instituto "Alfonso X el Sabio» de Murcia (1951-1954).
\end{abstract}

\section{RESUMEN}

El léxico de la educación entendido en sentido amplio, es decir, como la acción y resultado de transmitir o recibir algún conocimiento con voluntad de hacerlo, fue especializándose dentro de la literatura griega a lo largo de los siglos. Es un campo oportuno para obtener información sobre numerosas circunstancias sociales, políticas, económicas, familiares, culturales, etc. En los planos literario, léxico y semántico es posible seguir la evolución de algunos de los principales conceptos correspondientes al campo léxico de la educación (sustantivos, adjetivos, verbos) desde el propio Homero (siglo VIII a. C.), es decir, desde el comienzo de la literatura europea. Posteriormente, en la poesía arcaica puede rastrearse el desarrollo de los términos más destacados concernientes a la educación, todavía en un estadio preliminar. En cambio, en el siglo V a. C., gracias a la evolución de las condiciones sociales, económicas y políticas, los textos literarios nos ofrecen abundante información sobre diversos aspectos de la educación. El presente estudio no pretende recoger todo el léxico usado por Heródoto y Tucídides que roce de algún modo el campo de la educación, sino que se concentra en varias familias léxicas relevantes. El trabajo abarca cuatro partes: $1 . \delta 1 \delta \alpha ́ \sigma \kappa \omega$ y su familia léxica; $2 . \pi \alpha \imath \delta \alpha \gamma \omega \gamma o ́ \varsigma$ y su campo léxico; 3. $\pi \alpha \imath \delta \varepsilon i ́ \alpha-\pi \alpha \imath \delta \varepsilon v ́ \omega$ y su familia léxica; 4. $\mu \alpha v \theta \alpha ́ v \omega$ y su campo léxico. Con ayuda del TLG hemos revisado las obras de los dos historiadores, examinando todos los pasajes, viendo los contextos en que tales términos aparecen así como la relación u oposición respecto a otros vocablos relacionados con la educación, en sentido amplio.

Palabras Clave: Léxico, educación, Heródoto, Tucídides.

\section{OBSERVATIONS ON THE VOCABULARY OF EDUCATION \\ IN HERODOTUS AND THUCYDIDES}

\section{ABSTRACT}

The vocabulary of education understood in a broad sense, that is, as the action and result of transmitting or receiving some knowledge with the will to do so, was specialized in Greek literature throughout the centuries. It is a timely field to obtain information on numerous 
social, political, economic, family, cultural, etc. circumstances. In the literary, lexical and semantic planes it is possible to follow the evolution of some of the main concepts corresponding to the lexical field of education (nouns, adjectives, verbs) from Homer himself (VIII century BC), that is, from the beginning of European literature. Later, in archaic poetry the development of the most outstanding terms concerning education can be traced, still in a preliminary stage. In contrast, in the fifth century BC, thanks to the evolution of social, economic and political conditions, literary texts offer us abundant information on various aspects of education.

The present study does not intend to collect all the vocabulary used by Herodotus and Thucydides that rubs in some way the field of education, but concentrates in several relevant lexical families. The work covers four parts: $1 . \delta 1 \delta \alpha ́ \sigma \kappa \omega$ and its lexical family; $2 . \pi \alpha \imath \delta \alpha \gamma \omega \gamma o ́ \varsigma$ and its lexical field; 3. $\pi \alpha 1 \delta \varepsilon i ́ \alpha-\pi \alpha 1 \delta \varepsilon v ́ \omega$ and its lexical family; 4. $\mu \alpha v \theta \alpha \dot{v} \omega$ and its lexical field. With the help of the TLG we have reviewed the works of the two historians, examining all the passages, seeing the contexts in which those terms appear as well as the relation or opposition with respect to other words related to education, in a broad sense.

KEY WORDS: Education, lexicon, Herodotus, Thucydides.

El léxico de la educación entendido en sentido amplio, es decir, como la acción y resultado de transmitir o recibir algún conocimiento con voluntad de hacerlo, fue especializándose dentro de la literatura griega a lo largo de los siglos. Es un campo oportuno para obtener información sobre numerosas circunstancias sociales, políticas, económicas, familiares, culturales, etc. En los planos literario, léxico y semántico es posible seguir la evolución de algunos de los principales conceptos correspondientes al campo léxico de la educación (sustantivos, adjetivos, verbos) desde el propio Homero (siglo VIII a. C.), es decir, desde el comienzo de la literatura europea. Posteriormente, en la poesía arcaica (desde Arquíloco, en el siglo VII, hasta Píndaro y Baquílides, siglo $\mathrm{V}$ a. C.) puede rastrearse el desarrollo de los términos más destacados concernientes a la educación, todavía en un estadio preliminar. En cambio, en el siglo $\mathrm{V}$ a. C., gracias a la evolución de las condiciones sociales, económicas y políticas, los textos literarios nos ofrecen abundante información sobre diversos aspectos de la educación.

He tenido ocasión de ocuparme en varios estudios anteriores del léxico de la educación en diversos autores griegos ${ }^{1}$. No pretendo recoger todo el léxico que roce de algún modo el campo de la educación, sino que me concentro en varias familias léxicas relevantes. El estudio quiere abarcar cuatro partes: 1 . $\delta 1 \delta \alpha ́ \sigma \kappa \omega$ y su familia léxica; $2 . \pi \alpha 1 \delta \alpha \gamma \omega \gamma o ́ s$ y su campo léxico; 3. $\pi \alpha 1 \delta \varepsilon i ́ \alpha-\pi \alpha 1 \delta \varepsilon v ́ \omega$ y su familia léxica; 4. $\mu \alpha v \theta \alpha ́ v \omega$ y su campo léxico.

\footnotetext{
* Acabado dentro del Proyecto FFI2017-82850-R del Ministerio de Economía y Competitividad.

[Agradezco las observaciones y sugerencias hechas por los dos evaluadores anónimos de este trabajo].

${ }^{1}$ Heródoto y Tucídides (2000c. Sólo los datos esenciales), Eurípides (1995), Aristófanes (1997a), Corpus Hippocraticum (2000, 2002), Platón (1997b, 2000a, b), Aristóteles (2004), Galeno (2003) y Sinesio (2016). Cf. la Bibliografía.
} 
En este trabajo revisaré ese vocabulario en Heródoto y Tucídides ${ }^{2}$, con los que se establece la historiografía griega que nos ha llegado. Aunque cercanos cronológicamente (les separan unos treinta años de diferencia) la intención de sus obras respectivas es distinta; diferentes también fueron los años que les tocó vivir y las circunstancias políticas y sociales en que se desenvolvieron. Con ayuda del TLG he revisado las obras de los dos historiadores, concentrándome en el léxico arriba apuntado, examinando todos los pasajes ${ }^{3}$, viendo los contextos en que aparecen así como la relación u oposición respecto a otros términos relacionados con la educación, en sentido amplio.

\section{HERÓDOTO}

Heródoto $^{4}$ nos ofrece una lengua ${ }^{5}$ muy rica, muy trabajada, un jonio literario, artificial, notable por su arcaísmo y simplicidad, producto quizá de sus muchos viajes así como del paso de su obra, primero, por Atenas y, posteriormente, por Alejandría. Gran imitador de Homero es, por otro lado, un formidable creador de léxico y nunca estuvo ajeno a las corrientes más avanzadas de su época ${ }^{6}$.

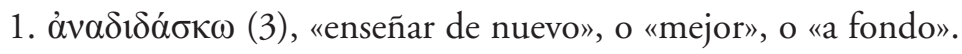

Heródoto es el primero en presentarlo. Por lo demás, constatamos pocos usos en los siglos VI-IV a. C.: Tucídides (3), Platón (1), Aristófanes (5), Aristóteles (2), etc. En la literatura posterior sobresalen Filón (93) y Proclo (104). Se ha visto que el preverbio ỏva-, a partir del sentido esencial de «abajo arriba», adquiere, en ocasiones, el valor

${ }^{2}$ Algunos estudiosos abordan aspectos que muestran la semejanza o diferencia entre ambos autores: cf. Hunter, 1982; Moles, 1993; Scardino, 2007; Foster-Lateiner, 2012; Will, 2015.

${ }^{3}$ Son 215 herodoteos y 83 tucidideos; en total 298 secuencias. De ellas recojo en el estudio sólo las relacionadas, lato sensu, con el campo de la enseñanza-educación.

${ }^{4}$ No sabemos casi nada sobre las fechas de su nacimiento y muerte, respectivamente en Halicarnaso y Turios. Una opinión extendida es la que sitúa su vida entre el 484 y algún momento posterior al 430: cf. Asheri-Lloyd-Corcella, 5. Pero algunos ponen el nacimiento en el 525 a. C., y otros piensan que murió hacia el 425. Muchos sostienen que redactó su obra (la Historíe, en nueve libros) entre 430 y 425 a. C. Un importante estudio general sobre el autor es el de Schrader, 1988.

${ }^{5}$ Entre los numerosos trabajos sobre diversos aspectos de la lengua del historiógrafo menciono unos pocos: van Groningen, 1958; Rosén, 1962; Wood, 1972; Dik, 1995; Slings, 2002; Bakker, 2006; Murray, sobre la oralidad, en Luraghi, 2007; Harrison-Irwin (eds.), 2018; Bowie (ed.), 2018, con aportaciones importantes sobre lengua, narración y ciencias; etc.

${ }^{6}$ De la estrecha relación entre el pensamiento del autor y la forma literaria de su obra señalo dos trabajos: Immerwahr, 1967; Lateiner, 1989. En torno a la presencia y uso de la retórica en el mencionado escritor, véanse, entre otros, Cogan, 1981 y Zali, 2009. Para el empleo, dentro de su obra, de recursos normales en la sofística, acúdase, por ejemplo, a Dihle, 1962; Ubsbell, 1983, especialmente cap. III: «Herodotus and the sophistic movement», 339-399; Thomas, 2000. Sobre otros aspectos generales, aportan datos relevantes Marg, 1965; Bornitz, 1968; etc. 


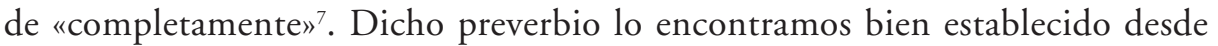
Homero $^{8}$.

La única secuencia herodotea donde hallamos el verbo citado en relación con el campo léxico que nos interesa es la siguiente:

Ese Zálmoxis ${ }^{9}$, conocedor del modo jonio de vida y de unas costumbres más reflexivas que las propias de los tracios - por haber tenido trato con griegos y precisamente con Pitágoras, no el más irrelevante sabio de los griegos-, mandó preparar un salón en el cual, recibiendo a los primeros de entre sus conciudadanos y ofreciéndoles banquetes, les enseñaba a fondo que ni él ni sus compañeros de bebida ni los que nacieran de éstos morirían, sino que llegarían a un lugar tal donde podrían disfrutar de todo tipo de bienes ${ }^{10}$.

Creo que el verbo tiene aquí el sentido de enseñar, transmitir, a otros una doctrina de carácter religioso, concretamente la que postula que, para determinadas personas o grupos, hay vida más allá de la muerte.

2. $\delta 1 \delta \alpha \sigma \kappa \alpha ́ \lambda ı$ เov (1), «lo que se enseña», «lo que es objeto de enseñanza».

Es una innovación del halicarnaseo, el único autor del siglo $\mathrm{V}$ que la regis$\operatorname{tra}^{11}$. Hace referencia a la cosa enseñada, a lo que es o ha sido objeto de enseñanza. Leemos lo siguiente: «Esos fenicios que llegaron con Cadmo - de entre los cuales eran

${ }^{7}$ Véase, Chantraine, 1968: 82.

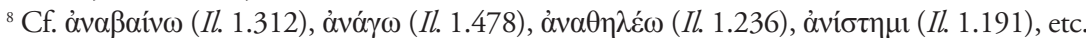

${ }^{9}$ Heródoto dedica un excurso (4.94-96) a este personaje que aparece en la literatura griega con diversas grafías ( $\left.\sum \alpha \dot{\lambda} \mu \mathrm{o} \xi_{1 \varsigma}, Z \alpha \dot{\alpha} \lambda \mu \mathrm{o} \xi 1 \varsigma, Z \alpha \dot{\alpha} \mu \mathrm{\nu} \lambda \xi 1 \varsigma\right)$ : según una tradición oral recogida por el escritor en el Helesponto y el propio Ponto, se trataba de un tracio que había sido esclavo en Samos, donde sirvió durante un tiempo a Pitágoras; finalmente regresó a su país donde logró hacerse rico. El halicar-

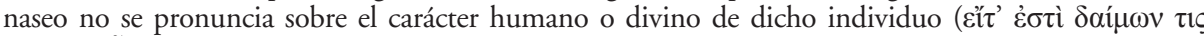

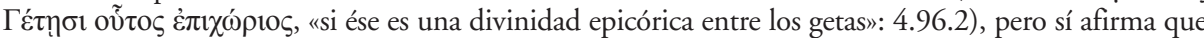
lo considera muy anterior al filósofo. Más información sobre el particular: Platón, Chrm. 158b (Sócrates habla de uno de los médicos tracios seguidores de Zálmoxis, de los cuales se decía que daban la inmor-

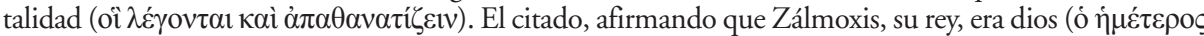

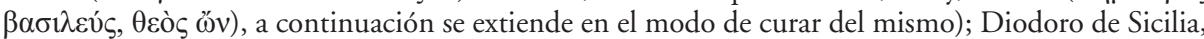
1.94; Estrabón, 7.3.5; 16.2.39; Porfirio, VP 15. Según How-Wells, 367, no cabe duda de que Zálmoxis era un dios tracio. Entre otras aportaciones dedicadas a la religión en el halicarnaseo, destaco dos: Burkert, 1990; Harrison, 2000. Respecto a la presencia de los tracios en el historiador, véase Pavlopoulou, 2006.

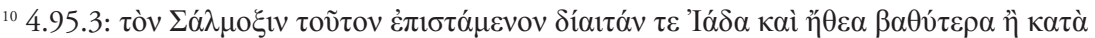

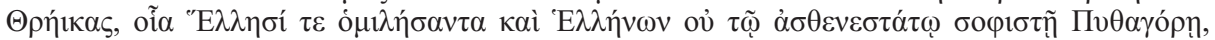

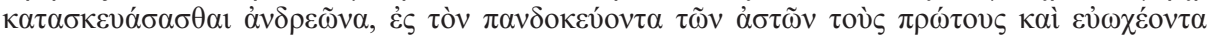

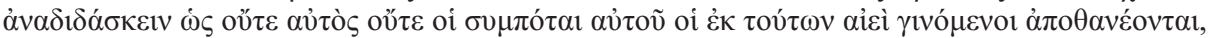

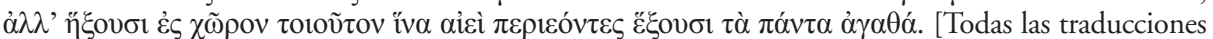
son mías].

${ }^{11}$ La ofrecen, después, entre otros, Jenofonte (1), Plutarco (10), Basilio de Cesarea (8), Juan Crisóstomo (7), etc. 
los gefireos ${ }^{12}-$, habitando esa región ${ }^{13}$, trajeron otras muchas enseñanzas a los helenos, y, especialmente, las letras ${ }^{14}$, no teniéndolas antes los helenos, según me parece; en primer lugar, las que usan todos los fenicios $»^{15}$.

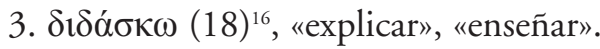

El verbo ya está presente en Homero con el valor de «domesticar», «explicar», «enseñar ${ }^{17}$. Presupone la inteligencia, o, al menos, la capacidad de aprender en el que recibe sus efectos, y, al mismo tiempo, el conocimiento y saber en el sujeto que ha de enseñar algo. Comporta, en el plano morfológico, el sufijo -sk-, que subraya, en cierto modo, la repetición sistemática ${ }^{18}$. Dentro del plano morfológico puede establecerse que el reparto de voces dentro del halicarnaseo es el siguiente: activa (9), media (5), pasiva (3). En el terreno semántico, conviene dejar a un lado los usos en que dicho verbo aparece con la acepción de «explicar», «aconsejar»". También hallamos

${ }^{12}$ Para muchos, los gefireos eran originarios de Eubea. En cambio, el halicarnaseo relaciona quizá el topónimo Gefira ( $\Gamma \varepsilon ́ \varphi v \rho \alpha$, antiguo nombre de Tanagra, en Beocia) con la ciudad de Gabhara, al sur de Fenicia. Cf. Schrader, IV: 104.

${ }^{13}$ Es decir, Beocia.

${ }^{14}$ Esta explicación sobre el origen del alfabeto griego coincide con el parecer casi unánime de los estudiosos, basado en la comparación de formas, nombres y orden de las primitivas letras fenicias y griegas. En todo caso el prosista se mantiene muy cerca de los hechos comprobados, fehacientes, y no recoge las lucubraciones de otros literatos que recurrieron a explicaciones míticas para justificar el origen de los caracteres griegos (Según el Fr. 531 Rose de Aristóteles, Estesícoro, en su Orestea, pensó en Palamedes y lo mismo hizo Eurípides; Esquilo, en Prometeo, dentro de la obra homónima; Mnaseas, en Hermes; otros, en Museo: cf. How-Wells: 432. Macan: I, 197, indica que los primeros testimonios de alfabetos griegos están documentados en las islas del Egeo, especialmente en Creta y Tera. La inscripción del Vaso del Dipilón (aprox. 740 a.C) figura entre los primeros testimonios escritos en alfabeto griego.

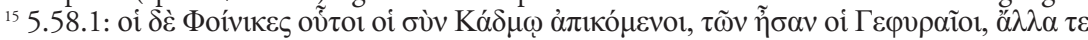

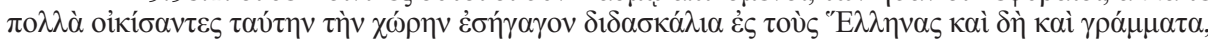

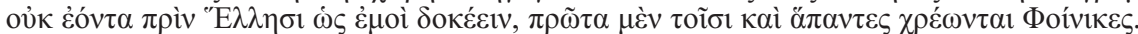

${ }^{16}$ Una lección es dudosa (1.84.3), por lo que contamos sólo 17 ejemplos.

${ }^{17} \mathrm{Cf} . \mathrm{Il} .9 .442 ; \mathrm{Od} .8 .488$.

${ }^{18}$ Schwyzer: I, 706.

19 9.31.2: «Y (sc. Mardonio) hacía esas cosas, por indicarlo y explicarlo los tebanos» ( $\tau \alpha \tilde{\tau} \tau \alpha$

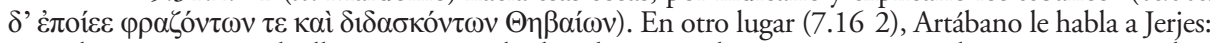
«Pues los ensueños que les llegan errantes a los hombres son tales como te voy a explicar, pues soy muchos

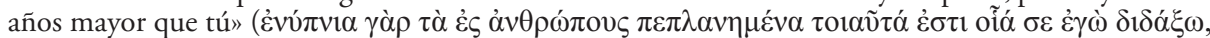

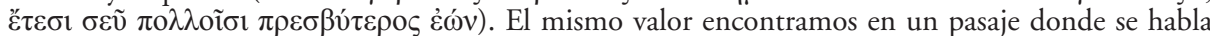
de los trescientos niños, nacidos en las familias más destacadas de Corcira, enviados a la corte de Aliates, en Sardes, para ser castrados: «Llegados a Samos los corintios que llevaban a los niños, tras haberse informado los samios del motivo por el que se les llevaba a Sardes, en primer lugar, les explicaron a los niños que se refugiaran en el santuario de Ártemis, y, después, sin permitir que apartaran del santuario a los suplicantes, como los corintios les impidieran a los niños recibir alimentos, los samios celebraron una

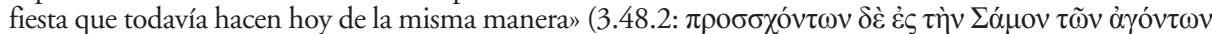

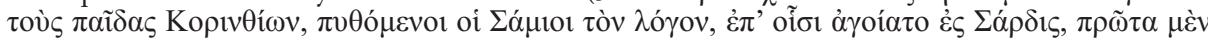

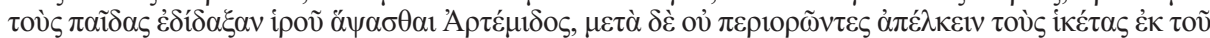

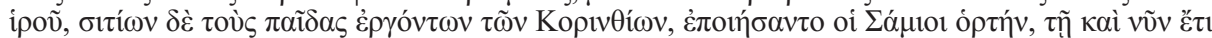

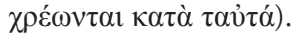


en el historiador el valor de «representar» un ditirambo ${ }^{20} \mathrm{o}$ un drama ${ }^{21}$. Podemos mencionar, asimismo, algunos ejemplos en que el vocablo alude a «domesticar», «amaestrar» un animal (cocodrilo ${ }^{22}$, caballo ${ }^{23}$ ), donde hallamos precisamente el participio medio-pasivo $\delta \varepsilon \delta 1 \delta \alpha \gamma \mu \varepsilon ́ v o \varsigma$, posiblemente como muestra del interés mostrado por los dueños de los citados. Por su lado, la voz pasiva, dentro de algunos usos absolutos, sin objeto directo, no nos permite concretar el valor del verbo que examinamos. Así lo vemos en una secuencia como ésta, donde la reina Atosa habla con Darío, su esposo, cumpliendo una petición que le hiciera su médico, Democedes, el cual le había curado un tumor importante. El texto no indica previamente qué le había indicado éste, aunque sí nos precisa que sería algo que no produjera vergüenza: «Pues bien, una vez que, tras eso, aplicándole un tratamiento la puso sana, entonces ya, informada por Democedes, Atosa le decía a Darío las siguientes palabras en la cama ${ }^{24}$. Pienso que, en esta secuencia, estamos en el límite entre «recibir información» o «explicación» y «atenerse a la enseñanza, precepto o indicación» recibidos de otro ${ }^{25}$.

Cercano al campo de la enseñanza, o incluido en él, leemos otro ejemplo cuando Megabizo $^{26}$ propugna la oligarquía y critica la democracia, a la que, viéndola como un sujeto personal (es decir, el pueblo), le niega la capacidad de entendimiento respecto a las acciones que pudiera acometer: «Pues ¿cómo comprendería el que ni fue educado ni conoció ningún bien propio, y, arrasando sus empresas, se precipita sin sentido, semejante a un río torrencial? ${ }^{27}$. El personaje hace referencia

${ }^{20} 1.24 .1$.

${ }^{21} 6.21 .2$.

${ }^{22} 2.69 .2$.

${ }_{23} 4.22 .2 ; 5.111 .1$.

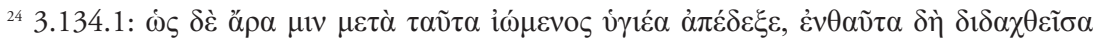

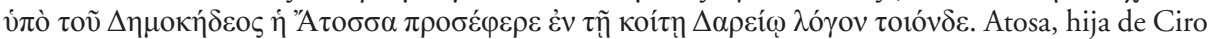
el Grande, tras estar casada con Cambises II y, después, con Esmerdis, fue la esposa de Darío I y madre de Jerjes. Esquilo la menciona en los Persas (155, etc.) con gran respeto. Padeció un tumor en el pecho (3.133); trató de ocultarlo al comienzo, pero, finalmente, Democedes se lo curó. Por su lado, Democedes de Crotón había sido médico oficial en Egina, Atenas y en Samos (3.131.1-3); posteriormente, tras haber sido reducido a la esclavitud, curó a Darío de una dislocación de tobillo, muy dolorosa; a partir de ese momento, figuró entre los personajes más notables de la corte persa. La presencia y función de las mujeres en la obra herodotea ha sido revisada, entre otros, por Blok, 2002, y Hazewindus, 2004.

${ }^{25}$ Otra secuencia semejante la leemos donde se nos habla de la hija del tirano Periandro, la cual había intentado convencer a su hermano, Licofrón, para que volviera a su país junto a su padre (3.53.5): «Ella, informada por su padre, le decía las palabras más convincentes, pero él, replicándole, afirmaba

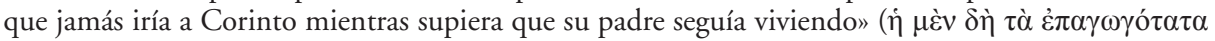

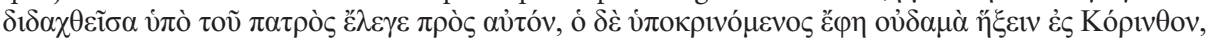

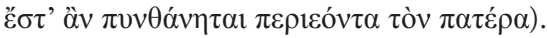

${ }^{26}$ Noble persa, uno de los siete que derrocaron al mago Esmerdis. Es un defensor a ultranza de la oligarquía. Sobre la crítica acerba contra la democracia entre los oligarcas a lo largo del siglo V, especialmente en Pseudo-Jenofonte, Constitución de los atenienses, 1.5, véase Schrader: III, 81.

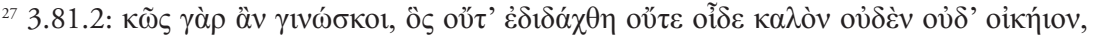

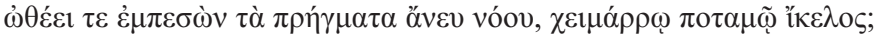




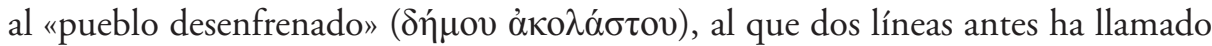

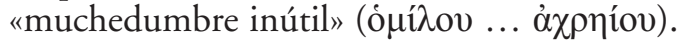

Muy próximo al valor que andamos buscando es lo que leemos cuando Artábano $^{28}$ habla del segundo de los dos planes propuestos a los persas: "Otro que hacía cesar ( $s c$. su desmesura) y que dice que es malo enseñar al espíritu a desear siempre tener algo más que lo presente ${ }^{29}$. Notemos la presencia del doble objeto de $\delta \delta \delta a ́ \sigma \kappa \varepsilon t v$.

A medio camino entre «explicar» y «enseñar» puede entenderse un pasaje como éste: «Las hijas de Dánao fueron las que trajeron ese rito ${ }^{30}$ desde Egipto y se lo enseñaron a las mujeres ${ }^{31}$ pelasgas ${ }^{32}$ ». El contexto, muy rico, hace referencia a las Tesmoforias ${ }^{33}$, fiestas rituales en honor de Deméter, sobre las que el escritor decide guardar discreto silencio. El de Halicarnaso sigue diciendo que, cuando, tras la llegada de los dorios, los peloponesios se vieron obligados a emigrar, ese rito se perdió casi por completo; sólo lo conservaron los arcadios, los únicos que no emigraron a parte alguna. La presencia del doble objeto directo, «explicar algo a alguien» nos permite pensar que estamos muy cerca del valor de «enseñar», o acaso ya dentro del mismo.

A partir de ahora recojo los pasajes que no nos plantean dudas respecto al valor de «enseñar» ofrecido por el verbo que estamos revisando.

3.1: «A Ariapites, rey de los escitas, le nace, entre otros hijos, Escilas ${ }^{34}$. Éste era hijo de una mujer istria ${ }^{35}$, de ningún modo natural del país; al cual su propia

${ }^{28}$ Hermano y consejero de Darío, función que desempeñó también con Jerjes, su sobrino.

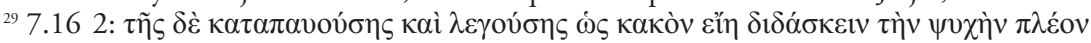

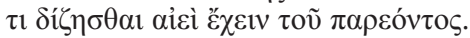

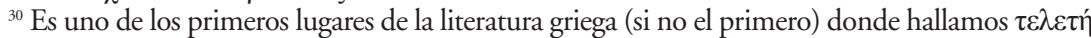
con el valor de «rito de iniciación», «iniciación»: cf. Eurípides, Ba. 22; Aristófanes, Nu. 304, Ra. 1032, etc. El sentido de "fiesta», "celebración religiosa», lo registran varios pasajes de Píndaro y Eurípides.

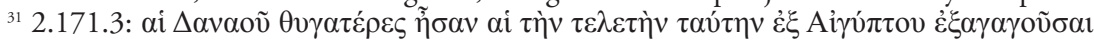

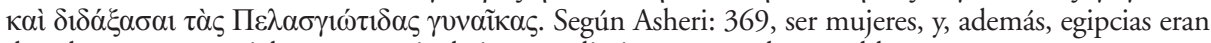
dos elementos esenciales para servir de intermediarias entre ambos pueblos.

${ }^{32}$ Para los pelasgos, cf. nota 41.

${ }^{33}$ Cf. How-Wells: 275, quienes destacan que la fiesta estaba en conexión con el tiempo de la siembra. Por las Tesmoforiantes de Aristófanes sabemos bien que el festival estaba reservado a las mujeres. Por su lado, el historiador quiere ver sus orígenes en Egipto, porque identifica a Isis con Deméter. No obstante esa explicación no es aceptada por muchos, pues ritos semejantes acontecen en pueblos distintos. Más información en Diodoro de Sicilia, 1.14, para la función de Deméter como introductora de la agricultura y de la ley.

${ }^{34}$ Rey escita, apasionado por las costumbres de los griegos. El escritor ofrece curiosos detalles de cómo se vestía de griego cada vez que llegaba a la ciudad de Borístenes (= Olbia), cómo se hizo construir allí un palacio donde tuvo por esposa a una mujer del lugar, cómo se hizo iniciar en los ritos báquicos y cómo, finalmente, todo eso le costó la vida, pues los escitas no toleraban ningún cambio en su modo de vida, y, menos, los excesos propios de los seguidores del dios Baco. Sobre el interés de nuestro historiógrafo por Escitia y Libia, consúltese Benardete: 99-132.

${ }^{35}$ Istria (de donde el gentilicio «istrio») estaba situada cerca de la desembocadura del Istro, es decir, el Danubio. La ciudad era llamada también Istro e Histra. Pues bien, Istria, colonia de Mileto, fundada en el siglo VII a. C., fue conocida desde la Antigüedad por sus relaciones comerciales con Samos, Rodas, y, algo después, con Atenas. En el siglo V comenzó la acuñación de monedas propias. Aunque Heródoto no da más explicaciones, cabe suponer que la madre de Escilas hablara, dentro de la lengua griega, el dialecto jónico, propio de Mileto. 
madre le enseñó la lengua griega ${ }^{36}$ y las letras $»^{37}$. Heródoto, aquí, en pocas palabras, transmite mucha información. En efecto, la mujer istria le enseñó a su hijo su lengua nativa, el griego, por pura comunicación oral, pero, además, le transmitió el conocimiento del alfabeto griego, y, con ello, lo habilitó para leer lo escrito en dicho idioma.

3.2: «Esas mujeres, según se fueron llenando de retoños, les enseñaban la lengua ática ${ }^{38}$ y las costumbres de los atenienses a sus hijos, los cuales no querían mezclarse con los hijos de las mujeres pelasgas, y cada vez que alguno de aquéllos era herido por alguno de éstos, todos le socorrían y se apoyaban mutuamente. E incluso los niños creían justo mandar sobre otros niños ${ }^{39} \mathrm{y}$ los dominaban con mucha fuerza ${ }^{40}$. Para entender bien la situación conviene acudir a varias fuentes donde leemos que los pelasgos ${ }^{41}$, tras llevarse algunas mujeres desde Atenas a Lemnos, las hicieron sus concubinas.

A partir de los dos últimos contextos, creo de extraordinario interés sociológico y cultural el hecho de que precisamente sean mujeres -unas madres- las primeras

${ }^{36}$ Hasta 12 veces registra el historiador la expresión «lengua griega», presente en él por primera vez en la literatura griega. Aparte de aquí, en 2.56 .3 ; 137.5; 143.4; 144.2; 154.2; 4.110.1; 155.3; $192.3 ; 6.98 .3$; 8.135.3; 9.16.2. Mucho más tarde recogerán la fórmula, entre otros, Dionisio de Halicarnaso (8 veces) y Filón de Alejandría (5 secuencias).

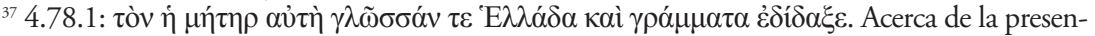
cia de los escitas en Heródoto, véase West: 437-456. En general, sobre la presencia de pueblos y lenguas bárbaras en el prosista, acúdase a Nenci-Reverdin, 1990, con trabajos especiales sobre árabes, indios, persas, cimerios, escitas, tracios, lidios, egipcios, libios y fenicios; Campos, 1992, especialmente 27-78, en torno a la lengua de los bárbaros y los problemas de comunicación y traducción; Bichler, 2000; Munson, 2005; etc.

${ }^{38}$ Macan: I, 393, indica que parece anacrónica la afirmación de que en esa época las mujeres atenienses hablaran ático.

${ }^{39}$ How-Wells: 534, creen que la explicación del escritor corresponde a una leyenda en la que se justificaría el dominio ateniense sobre Lemnos, y, por tanto, el de los niños atenienses sobre los naturales de dicha isla. Sobre un caso semejante, a saber, cómo un niño, especialmente dotado, se impone sobre sus iguales, véase en nuestro prosista (1.114-119) la leyenda referida a Ciro, cuando era, aparentemente, hijo de un boyero (siendo, en realidad, nieto de Astiages, rey de los medos).

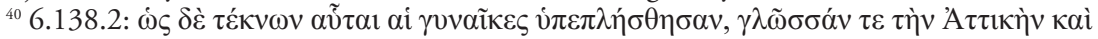

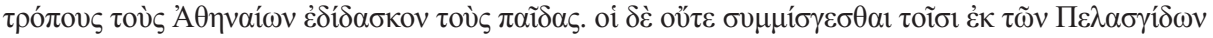

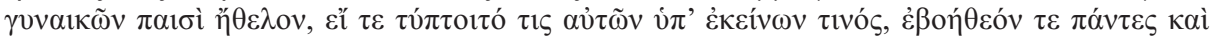

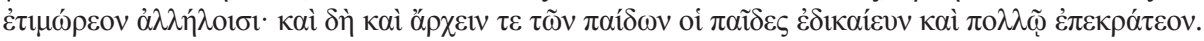

${ }^{41}$ El escritor explica (6.137) los motivos por los que los atenienses echaron de su territorio a los pelasgos, los cuales molestaban continuamente a las mujeres de aquéllos cuando ellas iban por agua: los expulsados se marcharon a la isla de Lemnos. En otro lugar indica que los pelasgos eran considerados por los griegos como habitantes autóctonos de la Hélade (5.27) y hablantes de una lengua no griega. El escritor (1.56.2) tiene a los atenienses por pelásgicos, mientras considera helénicos a los peloponesios. Añadamos que los pelasgos (Pelasgoî), pueblo prehelénico, están registrados desde Homero, donde se habla de "Argos pelásgica» (Il. 2.681), apuntando a una parte del reino de Aquiles, en Tesalia. Por otra parte, los trágicos recogen varios términos del tema pelasg-, relacionados, más o menos estrechamente, con Pelasgo (Pelasgós), epónimo primer rey de la Argólide, anterior a la llegada de Dánao. Un trabajo panorámico sobre los pelasgos lo ofrece Sourvinou-Inwood, 2003. 
que figuren desde Heródoto como transmisoras de la lengua (la griega, en general, sin más detalles, en un caso; el dialecto ático, en otro). Basándonos en ambos pasajes podemos afirmar que nunca estaría mejor dicho, por cierto, lo de «lengua materna».

3.3. Dos ejemplos del valor estudiado los tenemos en voz media. En el primero de ellos se nos informa de que Ciaxares, rey de los medos, acogió como suplicantes a unos escitas nómadas; los trató cortésmente y «les entregó unos niños para que aprendieran bien la lengua y la técnica de los arcos» ${ }^{42}$. Posteriormente, como esos escitas regresaran un día sin haber cazado nada, el soberano los trató de modo ofensivo y gran crueldad: «Y los que habían sufrido eso de parte de Ciaxares, habiendo sufrido algo indigno de ellos, decidieron hacer pedazos a uno de los muchachos que se educaban con ellos, y, tras prepararlo como tenían por costumbre preparar las piezas de caza, ofrecérselo a Ciaxares como si fuera caza $»^{43}$. Si examinamos los dos textos ofrecidos,

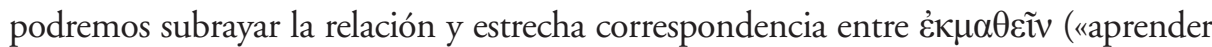
bien») y $\delta 1 \delta \alpha ́ \sigma \kappa \varepsilon \sigma \theta \alpha l$ («recibir enseñanza»). La secuencia nos llevaría a hablar de ciertos mitos bien conocidos en que los padres despedazan a sus propios hijos y se los ofrecen a otros comensales en un banquete ${ }^{44}$.

3.4. El segundo texto nos habla de las desgracias ocurridas a los quiotas. Efectivamente, tras la batalla naval de Lade (494 a. C.), Mileto cayó ante los persas. En la defensa de la ciudad habían colaborado valientemente los quiotas; derrotados en el combate naval, algunos se salvaron por tierra, pero, posteriormente, cayeron en manos

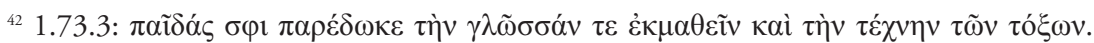
Respecto a la asociación de los escitas con el manejo del arco, véase Jenofonte, Mem. 3.9.2; Platón, Lg. 795a; etc. Por otro lado, todo apunta a que eran medos los niños entregados para que recibieran instrucción en la lengua escita y en el manejo del arco. Ciaxares reinó en Media durante cuarenta años (1.106.3); fue padre de Astiages, cuya hija, Mandane, casada con Cambises, rey de Persia, fue la madre de Ciro el Grande. El hecho de que el rey de un pueblo importante (el medo) mostrara interés en que unos niños de su territorio aprendieran escita podría justificarse por motivos de frontera o económicos. Sobre la lengua escita, véase nota 98.

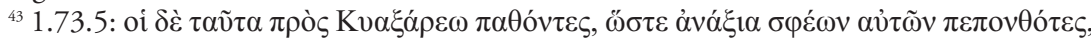

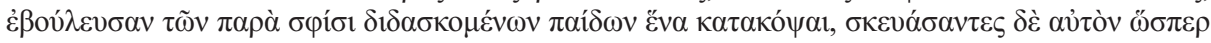

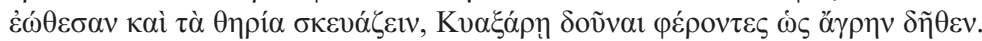

${ }^{44}$ El historiador (1.118-119) recoge lo sucedido a Harpago, pariente y hombre de confianza de Astiages, rey de los medos. Éste, para vengarse de la omisión cometida por aquél, que había recibido la orden de eliminar al nieto del monarca (el niño que luego sería Ciro), le ofreció en un festín las carnes cocinadas de su hijo adolescente. Por lo demás, la literatura griega nos provee de varios ejemplos míticos paralelos. En primer lugar el caso de Procne, la cual mató a su hijo y se lo presentó como manjar a su esposo, Tereo, porque éste había violado a Filomela, hermana de la citada, y, además, le había cortado la lengua para que no dijera nada de lo sucedido. En segundo, el mito famoso de Tántalo, quien, tras dar muerte a su propio hijo Pélope, se lo sirvió a los dioses en un banquete para cerciorarse de si las divinidades lo sabían todo. En tercer lugar, el de Atreo, hijo de Pélope, pues acabó con la vida de sus sobrinos, los hijos de Tiestes, a quien se los dio a comer en un festín. Halm-Tisserant, 1983, presenta un estudio interesante sobre diversos mitos griegos relacionados con la muerte de los propios hijos a manos de sus padres y el banquete en que éstos ofrecen las carnes de los mismos. 
del enemigo y fueron ejecutados. Con anterioridad al desastre marítimo, en su ciudad natal, Quíos, habían sucedido otras desventuras: «Y, además, en la ciudad, por las mismas fechas, (sc. ocurrió) lo siguiente, poco antes de la batalla naval: a unos niños que estaban aprendiendo las letras les cayó encima el techo, de modo que, de ciento veinte niños, uno solo escapó. Ésas señales ${ }^{45}$ les demostró de antemano el dios ${ }^{46}, y$, tras eso, la batalla naval, sorprendiendo a la ciudad, la puso de rodillas, y, tras la batalla naval, se presentó Histieo ${ }^{47}$, conduciendo a los lesbios» ${ }^{48}$.

El escritor poco antes de los hechos que hemos recogido apunta que, cuando sobre una ciudad o una nación, van a caer grandes desdichas, suele ${ }^{49}$ haber algún

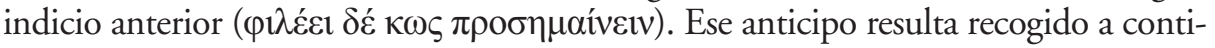
nuación por los $\sigma \eta \mu \eta ́ 1 \alpha$ que leemos unas líneas después.

Conviene señalar varios detalles: los niños se encontraban en un único lugar (quizá una escuela o local similar); el edificio -si es que no se vino abajo por causa de algún terremoto, no mencionado en el pasaje- no tendría buenas condiciones ${ }^{50}$;

${ }^{45}$ En griego, $\sigma \eta \mu \eta ́ 1 \alpha$. En el párrafo se habla de un «dios»; luego dicho sustantivo podría entenderse como "presagio", "prodigio».

${ }^{46}$ Posiblemente Apolo, pues el santuario de Delfos aparece en la secuencia unas líneas antes, donde leemos que los quiotas habían enviado allí un coro de cien muchachos, de los cuales sólo dos regre-

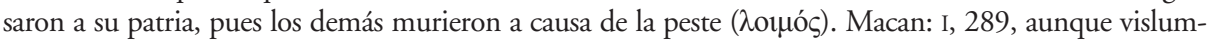
bra una cierta alusión a Apolo y la peste enviada por el dios tal como los vemos al comienzo de la Ilíada (Il. 1.44), sugiere que se trataría más bien de Zeus, pues en Heródoto hay una tendencia visible hacia el monoteísmo o monismo, como comprobamos en una serie de pasajes $(3.108 .1 ; 6.98 .1 ; 8.13)$.

${ }^{47}$ Antiguo general ateniense al que, por sus servicios a los persas, Darío nombró tirano de Mileto. Hombre ambicioso y de proceder ambiguo, fue para muchos uno de los responsables de la insurrección de los jonios frente al imperio persa.

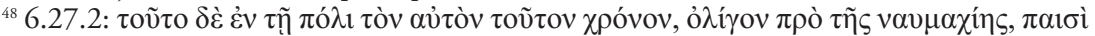

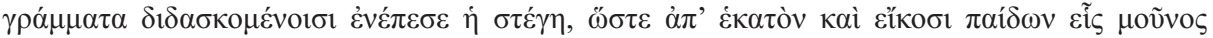

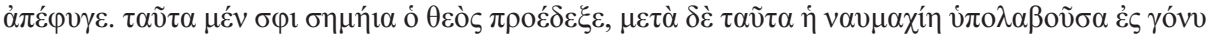

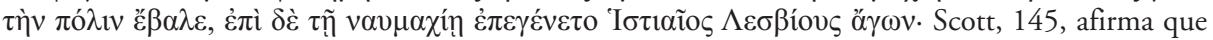
tanto este pasaje como el ofrecido por Pausanias (6.9.6), referido a Astipalea (pequeña isla del archipiélago del Dodecaneso, situada entre Naxos y Rodas) y datable en el 496 a. C., apuntan a las fechas más antiguas en que se habla de una escuela. La literatura griega nos habla de personajes ilustres preocupados por la educación de los niños en fechas anteriores a las señaladas. Así, Diodoro de Sicilia (12.12.4) indica que Carondas, legislador de Catania (de fecha incierta: desde mediados del VII a finales del VI a. C.), redactó leyes para que todos los niños aprendieran a leer, preocupándose incluso por el salario que había que dar a los maestros; y Esquines (1.7-11) alude a las leyes de Dracón y Solón (respectivamente, 621/620 y 594 a. C.) para la enseñanza de los niños. Por lo demás, desde principios del v, al menos, diversos vasos muestran escenas de niños aprendiendo a leer. Plutarco (Them.10.5) menciona la escuela de Trecén a la que acudieron los hijos de los refugiados atenienses en el $480 \mathrm{a}$. C., cuando huyeron de su ciudad a causa de la invasión de los persas.

${ }^{49}$ How-Wells: 482, creen que no se trata de una forma impersonal, sino que el sujeto es «un dios».

${ }^{50}$ Es sabido que la isla de Quíos, de origen volcánico, situada entre la placa anatolia y la euroasiática, ha sufrido numerosos movimientos telúricos; algunos, de triste memoria. El peor ocurrió en 1881, con una magnitud estimada de 7.3 (Richter) y casi 4.000 muertos sólo en la isla. 
el número de niños era bastante elevado; los escolares recibían la enseñanza de las letras del alfabeto (lectura y escritura) ${ }^{51}$; es importante, en mi opinión, la ausencia del sujeto responsable de impartir la enseñanza, pues el modo sintáctico de expresar que los niños estaban aprendiendo algo es la voz media, que nos aporta poca información. Con dicha voz se muestra el interés del escritor en la acción verbal, y, si acaso, el modo favorable con que los niños la recibían; el autor desea precisar que sólo uno, de los 120, se salvó. No olvidemos que líneas más arriba el prosista había señalado que, de los cien enviados a Delfos, sólo dos habían escapado de la peste. Por último, las formas gramaticales correspondientes a los niños $(\pi \alpha 1 \sigma i ̀ ~ . . . \pi \alpha i ́ \delta \omega v)$ sin ningún determinante, no nos permite saber si había escolares de los dos sexos.

En el plano histórico, pensemos que estamos en los primeros años del siglo $\mathrm{V}$ a. C.: es una de las primeras noticias sobre los locales en que se impartía la enseñanza. Sabemos, por lo demás, que, desde comienzos de ese siglo, había, en diversos lugares, escuelas para muchachos, donde se enseñaban la lectura y escritura, quizá con fines económicos y comerciales ${ }^{52}$.

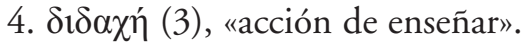

El sustantivo surge en el siglo V. Es un término técnico que leemos en Demócrito, Heródoto, Tucídides, etc. En Heródoto encontramos dos empleos en que puede entenderse como la recomendación o instrucción recibida ${ }^{53}$. Un tercer ejemplo, en cambio, está muy cerca del campo de la educación. En él, se está hablando de los fenicios que habían venido a Beocia con $\mathrm{Cadmo}^{54}$, considerándolos introductores del alfabeto en Grecia:

Pero, pasando el tiempo, junto con la pronunciación, cambiaron también la forma de las letras. Durante aquel tiempo, en la mayoría de los lugares les rodeaban, de entre los helenos, los jonios, los cuales, habiendo recibido, mediante enseñanza, las letras de parte de los fenicios, tras introducir pequeños cambios ${ }^{55}$, las utilizaban, y, utilizándolas,

${ }^{51}$ How-Wells: 482, señalan que lectura y escritura eran enseñadas en las escuelas públicas para niños. Scott: 145, insiste en que hasta la mitad del vi la escritura se usó casi exclusivamente para redactar las leyes (véase Gagarin: 59-77) y dedicatorias religiosas.

${ }^{52}$ Macan: I, 289. Scott: 145, recuerda que una inscripción de Quíos, fechable en el VI a. C. ( $M L$ 8, p. 46, n. 162 de Meiggs-Lewis) contiene las reglas generales para el funcionamiento de una escuela, y es anterior a la de Lócrida ozolia (525-500 a. C.: $M L 13)$.

53 3.134.4; 5.70.2.

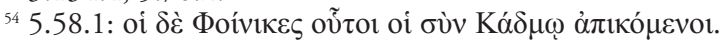

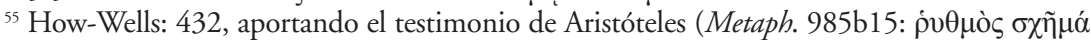

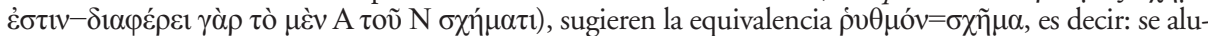
diría aquí a «la forma», «la figura». Además, los citados estudiosos señalan que el historiador parece no haber reparado en tres modificaciones muy importantes: la utilización de ciertas consonantes fenicias para representar las vocales a, e, i, o, así como la adición de u, è, ō; la evolución hasta llegar a la representación de la phi, chi y psi; la desaparición de algunas sibilantes innecesarias, aunque observa la conservación de la san además de la sigma. En todo caso el interés del escritor parece centrarse más en la forma que en el sonido de las letras. 
declararon -como, además, era lo justo, al haberlas introducido unos fenicios a la Hélade- que se llamaban 'Fenicias ${ }^{56}{ }^{\prime 57}$.

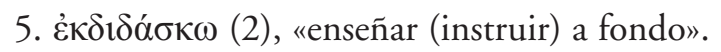

Precisamente, de las dos secuencias que ofrece el historiador de Halicarnaso, hay una en que ese verbo aparece con el valor de "recibir enseñanza" ${ }^{58}$. El pasaje nos presenta al faraón Psamético I, el cual, agradecido con los jonios y carios ( $\tau$ oĩ $\sigma \hat{\delta} \grave{\varepsilon}$

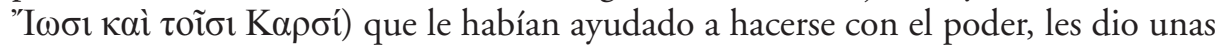
tierras junto al Nilo: «Y además, les entregó unos niños egipcios para que les fuera enseñada a fondo la lengua griega; $y$, de ésos que aprendieron bien la lengua, son los actuales intérpretes ${ }^{59}$ que hay en Egipto ${ }^{60}$.

${ }^{56}$ Entiéndase Фoเvıкท́ı, no como adjetivo, sino con la función de sustantivo, referido a las letras de ese origen, sentido que aparece en algunas inscripciones. Así, en How-Wells, ibid.

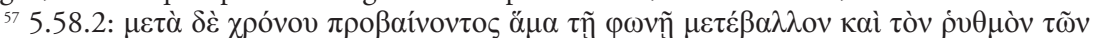

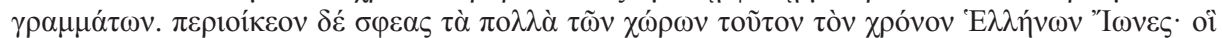

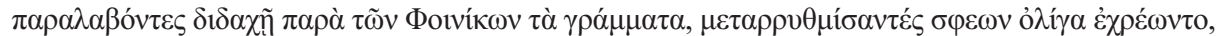

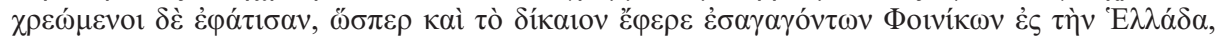

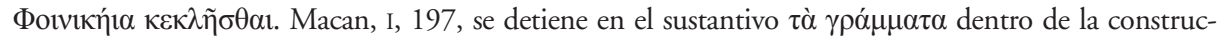
ción sintáctica pertinente, y concluye que, según lo plantea el escritor, resultan dos postulados: por un lado, el origen fenicio del alfabeto; por otro, que los fenicios establecidos en Beocia lo introdujeron, o se lo enseñaron, a los griegos. Pero, del contexto se deduce un tercer punto esencial: que fueron los jonios limítrofes quienes, tras haber recibido el alfabeto fenicio de parte de los fenicios establecidos en Beocia, modificaron las letras, las adaptaron, utilizaron y les dieron nombre. Por su lado, How-Wells, ibid.,

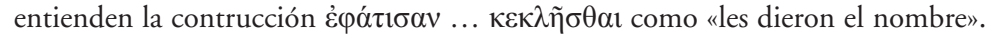

${ }^{58}$ En la otra (4.118.1) el verbo equivale a «explicar», «contar con detalle».

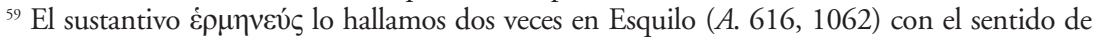
«intérprete» $y$, en ambos pasajes, con el calificativo de «fiel, exacto»: en el primer caso, de las palabras de Clitemnestra; en el segundo, de la actitud de Casandra, que no había dicho nada hasta entonces. No obstante en el siglo $\mathrm{V}$ y comienzos del IV quienes más usan el término son Heródoto (8) y Jenofonte (12). El de Halicarnaso lo emplea en distintos contextos. Me he permitido hacer un extracto de los distintos usos del mismo por considerar que dicha profesión, al parecer del escritor, estaba en íntima relación con los egipcios que en su día aprendieron el griego gracias a las enseñanzas de los jonios: lo tenemos cuando Ciro no entiende a Creso (que hablaría griego), 1.86.4; 86.6; cuando alguien le tradujo al historiógrafo lo escrito en la Pirámide de Keops, 2.125.6; cuando leemos que los intérpretes, por su lado, forman una de las siete castas egipcias, 2.164.1; además, como Darío les hiciera unas preguntas a los indios calatias, los que se comen los cadáveres de sus propios padres, los griegos presentes seguían la respuesta valiéndose de intérpretes, 3.38.4; los intérpretes reales del palacio de Susa atienden a un griego (Silosonte) que había llegado allí diciendo que era benefactor del monarca, 3.140.3; los escitas, cuando van al país de los calvos (los argipeos), usan siete intérpretes que hablan siete lenguas, 4.24.

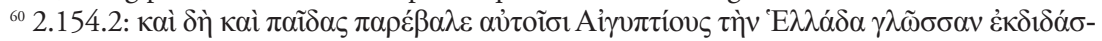

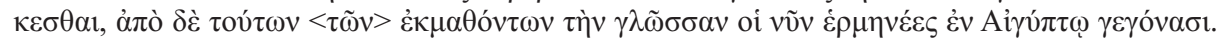
Lloyd (Asheri: 355) duda que los intérpretes que conoció Heródoto fueran descendientes de los aquí mencionados. 
Puede y debe subrayarse la estrecha correspondencia entre $\dot{\varepsilon} \kappa \delta เ \delta \alpha ́ \sigma \kappa \varepsilon \sigma \theta \alpha$,

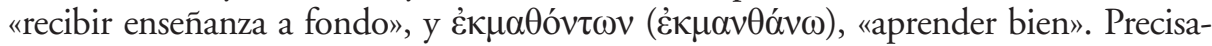
mente este último verbo está bien registrado en Platón con el sentido de «aprender totalmente», «de memoria ${ }^{6}{ }^{6}$; el valor de insistencia, de perfección y acabamiento, viene conferido por el preverbio $\dot{\varepsilon} \kappa-{ }^{62}$. Sucede lo mismo en el caso de $\dot{\varepsilon} \kappa \delta t \delta \alpha ́ \sigma \kappa \omega$. Pues bien, si recordamos que Psamético I gobernó Egipto desde 663 hasta 609 a. C., puede apreciarse aún más el sentido práctico del faraón, al buscar que esos niños seleccionados aprendieran el griego, quizá con fines comerciales. En todo caso, según el escritor, de los citados procederían los intérpretes existentes en su propia época. Naturalmente, en dicha ocasión, los encargados de enseñar la lengua griega habrían sido los jonios, dado que los carios, por lo general, no hablaban griego ${ }^{63}$.

\section{6. $\pi \alpha \_\delta \alpha \gamma \omega \gamma o ́ \varsigma$ (1), «acompañante del niño, educador».}

Dicho sustantivo está registrado sólo una vez en Heródoto, donde resulta ser una innovación léxica. Posteriormente lo recogen, entre otros, Eurípides (2) y Platón (18): en el filósofo ocupa un lugar relativamente importante. Es el que acompaña al niño cuando va y viene de la casa del maestro, y tiene una función fundamental bien expuesta por el pensador: evitar que los niños anduvieran solos y fueran sometidos a violencia o agravio, especialmente en el terreno sexual ${ }^{64}$.

El de Halicarnaso nos refiere que, reunida la flota griega en Salamina, surgió descontento entre los soldados. Temístocles, jefe de los atenienses, envió al campamento de los medos un hombre en una barca, con el fin de que, mediante una añagaza, incitara al enemigo a entrar en batalla: «Su nombre era Sicino, y era un criado, y, además, pedagogo de los hijos de Temístocles»" ${ }^{65}$. El pasaje es muy parco y apenas

${ }^{61}$ Los ejemplos platónicos los hallamos en Phdr. 228d, Hp. Ma. 285e; etc.

${ }^{62}$ Véase, Chantraine, 1968: 352.

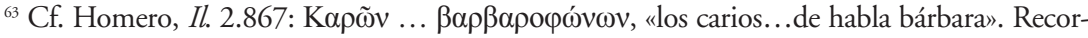
demos que Caria estaba situada al sureste de Asia Menor, cerca de Mileto y del valle del río Menandro. El cario es una lengua indoeuropea procedente del grupo anatolio, hablada en la región de Caria, situada en el suroeste de la actual Turquía. Para su estudio han sido esenciales las inscripciones de más de 100 tumbas halladas en Egipto, donde, durante los siglos VII-V a. C., numerosos carios sirvieron como mercenarios de los faraones.

${ }^{64}$ Cf. Smp. 183 c.

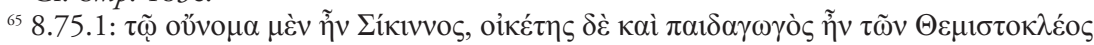
$\pi \alpha i ́ \delta \omega v$. Plutarco (Them. 32) afirma que el estadista ateniense tuvo cinco hijos. Por lo demás, Polieno (1.30.3) tiene posiblemente razón cuando alude a Sicino como el pedagogo de «los dos hijos» de Temístocles, pues es muy probable que, cuando aconteció la Batalla de Salamina (480 a. C.), sólo dos ellos estuvieran en edad de tener tutor: véase Macan: IV, 475. De otro lado, How-Wells: 681-682, insisten en que Sicino era griego, como lo leemos en Esquilo (Pers. 355), e indican que Plutarco (Them. 12) puede estar en un error al tomarlo por persa. En todo caso, podría tratarse de un griego asiático. Para la presencia de Temístocles en el historiador, cf. Goldscheider, 1965; Blösel, 2004. 
permite extraer unas pocas conclusiones. Efectivamente, algún estudioso de Heródoto ha entendido el sustantivo como "preceptor», "tutor», «educador», es decir, maestro él mismo, aparte de acompañante de los niños ${ }^{66}$. En Eurípides, el sustantivo equivale al sentido general que tendrá definitivamente en Platón. Por lo demás, en Sófo-

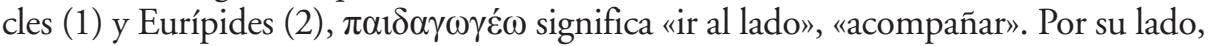
Platón nos habla de un pedagogo que era esclavo ${ }^{67}$. No obstante, un pasaje platónico presenta a Fénix como pedagogo de Aquiles ${ }^{68}$ : en el filósofo, pues, y sólo en dicho caso, tendríamos que aceptar el significado de «educador» para el término que venimos examinando.

7. $\pi \alpha i ́ \delta \varepsilon v \sigma ı \varsigma ~(2)$, «acción de enseñar, de educar»,«educación».

Innovación herodotea: uno de los muchos nombres de acción con sufijo

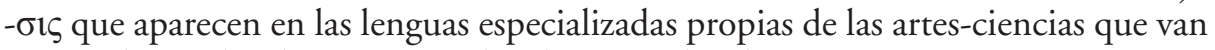
surgiendo en el siglo $\mathrm{V}$. Veamos los dos ejemplos de nuestro autor.

7.1: «Y a Escilas ${ }^{69}$, aun siendo rey de los escitas, de ninguna manera le gustaba el régimen de vida escita, sino que estaba mucho más inclinado hacia las costumbres helénicas a causa de la educación que había recibido $»^{70}$. No debe olvidar-

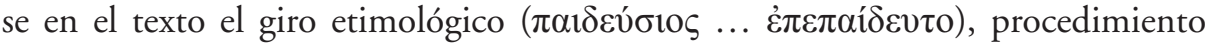
léxico apropiado para insistir en la idea más relevante. Es algo muy corriente en poesía, pero no ajeno a la prosa, como vemos; repárese también en el valor etimológico de $\pi \alpha 1 \delta \varepsilon v ́ \omega$.

7.2. El segundo texto herodoteo lo encontramos a propósito de Clístenes, tirano de Sición, que decidió dar su hija en matrimonio al que más le agradara a él por sus méritos relevantes ${ }^{71}$. Atraídos por la propuesta, se presentaron trece pretendientes. Una vez llegados ésos en el día señalado, leemos: «Clístenes, primeramente, se informó de sus patrias y del linaje de cada uno, y, posteriormente, reteniéndolos durante un año, les hacía pruebas sobre su hombría de bien, inclinación, educación y modo de ser, entrevistándose con cada uno por separado y con todos

${ }^{66}$ Macan: IV, 475.

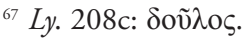

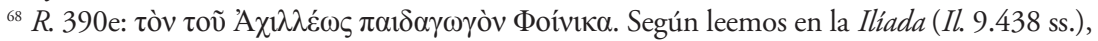
Peleo había enviado a su hijo Aquiles, niño aún, a casa de Fénix para que éste le enseñara a ser «orador

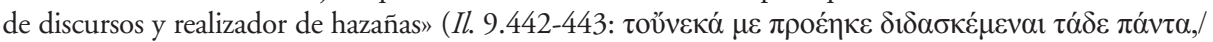

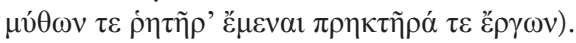

${ }^{69}$ Para el personaje, recordemos lo que hemos dicho en la nota 34 .

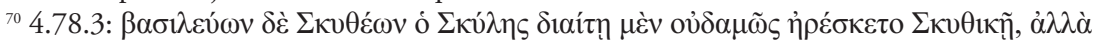

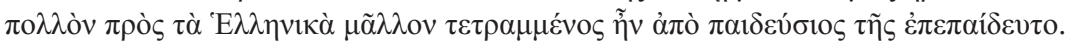

${ }^{71}$ El cuento popular donde se relatan hechos semejantes es bien conocido en diversas literaturas. Entre otros, han examinado la presencia del mismo en el historiador Aly, 1969 y Luraghi, 2013. 
en conjunto» ${ }^{72}$. Pienso que el sustantivo $\pi \alpha i ́ \delta \varepsilon v \sigma i \varsigma$ debe interpretarse aquí, no como un simple nombre de acción en -sis, la acción de enseñar considerada en su desarrollo durativo, evolutivo, sino con un valor especialmente conclusivo, terminativo: la educación que los aspirantes a la mano de la hija de Clístenes poseían en aquel momento por haberla recibido hasta entonces.

8. $\pi \alpha 1 \delta \varepsilon v ́ \omega ~(3)$, «educar», «enseñar».

Encontramos el verbo a partir del siglo VII, en un fragmento de Safo (1), pero se generaliza en el v: Píndaro (1), Sófocles (6), Eurípides (9), Antifonte (1), los dos historiadores que estudiamos, etc. En Heródoto conserva el sentido etimológico ${ }^{73}$, es decir, una estrecha relación con $\pi \alpha i ̃ \zeta$.

8.1. He aquí la primera secuencia: «(sc. Los persas), comenzando desde los cinco años y hasta los veinte, enseñan ${ }^{74}$ a sus hijos ${ }^{75}$ sólo tres cosas: montar a caballo, disparar el arco y decir la verdad ${ }^{76}, 77$. Posiblemente este trío de la paideía persa pudiera ser

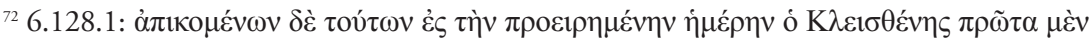

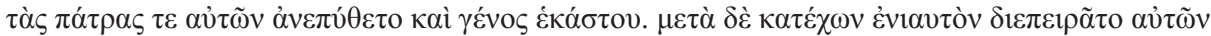

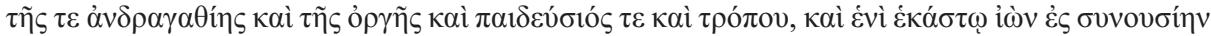

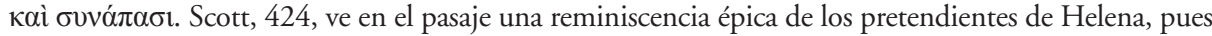
incluso el vocabulario nos permite pensar en los ideales del mundo aristocrático homérico: familia, honor y pruebas físicas. La primera mención de la pareja léxica «pretendientes»-«Helena» la hallamos en Hesíodo (Fr. 204.42-43, 55.58).

${ }^{73}$ Kennedy: 45-46, ha señalado el interés de Heródoto por la etimología, los juegos etimológicos, la estructura formal de los discursos, el uso de antítesis y otros rasgos de carácter especialmente sofístico.

${ }^{74}$ Con respecto a los verbos fundamentales que sirven para expresar la idea de «enseñar», «educar», son significativos los ejemplos de Platón y Aristóteles, en los cuales tenemos las siguientes cifras, respectivamente, de $\delta ı \delta ́ \sigma \kappa \omega-\pi \alpha ı \delta \varepsilon v \omega: 221-73$; 163-68. Observamos en el primero que el número de ejemplos del verbo ahora considerado compite con $\delta 1 \delta \alpha ́ \sigma \kappa \omega$, a corta distancia del mismo. En todo caso, $\pi \alpha 1 \delta \varepsilon v ́ \omega$ fue bastante menos utilizado que $\delta i \delta \alpha ́ \sigma \kappa \omega$ en todo el periodo clásico: cf. López Férez, 2000b: 61. Según el TLG, en línea, el total de ambos verbos dentro de la literatura griega es: $\delta 1 \delta \alpha ́ \sigma \kappa \omega$ (38.517)- $\pi \alpha 1 \delta \varepsilon v ́ \omega ~(10.521)$.

${ }^{75}$ En el presente pasaje, $\pi \alpha i \check{\varsigma}$ funciona con el sentido de «hijo». No obstante, desde siempre hubo entre los griegos un interés por delimitar las edades de la vida. Así, por poner un ejemplo del médico más importante, y con respecto a las primeras etapas de la vida, en los tratados galénicos la edad del niño ( $\pi \alpha \tilde{i} \varsigma$, con 427 alusiones) oscila desde recién nacido hasta los 18 años; por su lado, el $\pi \alpha 1 \delta$ óov

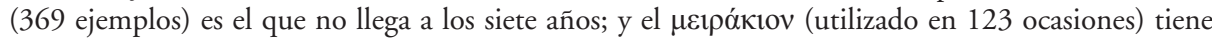
una edad comprendida entre los 18 y los 25 años. Notemos que en el texto del escritor estamos ante un periodo extenso de la vida, pues abarca quince años, si nos atenemos al criterio de Galeno. Por otra parte, un detalle interesante es que el sujeto de «enseñan» son los propios persas, pues no se habla aquí de maestro alguno.

${ }^{76}$ Otra innovación léxica herodotea es el verbo $\alpha \lambda \lambda \eta \dot{\jmath} \zeta \omega$, presente tres veces en su Historia. Vocablo bastante raro, no lo volvemos a encontrar hasta el siglo II d. C., en los escritos plutarqueos (1). Sayce, 81, señala la importancia que los persas daban a la «verdad» a la luz de la inscripción de Behistún, 
una interpretación del historiador basada en fórmulas orientales dedicadas a la glori-

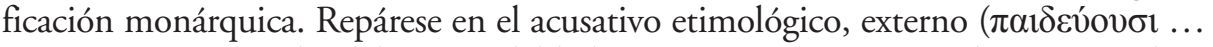
$\pi \alpha i \tilde{\delta} \alpha \varsigma)$, como prueba del interés del halicarnaseo por insistir en el concepto clave dentro de la frase. Por otro lado, que los persas supieran montar a caballo fue una decisión tomada por Ciro, si hacemos caso de lo que nos cuenta Jenofonte ${ }^{78}$.

8.2. Un segundo ejemplo recoge la recomendación que Creso le dio a Ciro a propósito de los lidios: «Y mándales que enseñen a sus hijos a tocar la cítara, hacer vibrar las cuerdas musicales ${ }^{79}$ y comerciar al pormenor; y rápidamente, joh rey!, los verás convertidos en mujeres en vez de hombres, de modo que no te ofrecerán ningún peligro de que vayan a hacer defección $»^{80}$. El historiador se hace eco de la vida un tanto afeminada de los lidios de su tiempo, muy distinta de la que cabría esperar de su pasado guerrero ${ }^{81}$. En el plano sintáctico y estilístico es relevante de nuevo la presencia del acusativo etimológico, modo expresivo de recalcar la idea clave del pasaje.

8.3. El tercer texto lo hemos visto ya al hablar de $\pi \alpha i ́ \delta \varepsilon v \sigma ı \varsigma^{82}$.

9. $\dot{\alpha} \mu \alpha \theta \eta ́ \varsigma \varsigma(2)$, «ignorante, estúpido».

El adjetivo, dotado de una alfa privativa, indicadora de carencia o ausencia de la idea aportada por el tema correspondiente $(\mu \alpha \theta-)$, y con el valor de «ignorante,

en la que Darío menciona varias veces el valor de la «verdad» y execra la mentira y los mentirosos. Por otro lado, el mismo investigador apunta que, a pesar de las palabras de Heródoto, la educación de los persas no podía ser iletrada, basándose en el interés de Darío en que la inscripción mencionada (trilingüe: persa antiguo, elamita y babilonio; y de enorme tamaño: 15 metros de alto y 25 de ancho) estuviera al lado del camino real. Con todo, dada la distancia de la misma hasta un posible lector (más de 100 metros), sería casi imposible leerla a simple vista y, además, estaba en un sitio casi inaccesible. Brosius (Asheri: 528-537) recoge la indicada inscripción. A su vez, S. West, 1985, examina el interés del historiador por textos epigráficos.

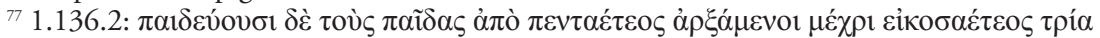

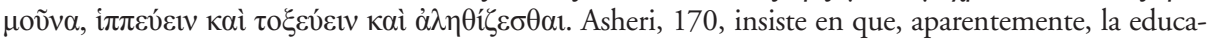
ción persa no comprendía la lectura ni la escritura, asunto que fue idealizado entre los grupos conservadores griegos: Jenofonte (An.1.9.2-6; Cyr.1.2.3-12), Platón (Alc.I 121e-122a), Onesícrito, (FGH 134 F 35); etc.

${ }^{78}$ Cyr. 1.3.3. How-Wells: 132, exponen que la caballería, poco desarrollada en un país tan montañoso como el persa, empezaría a ser importante cuando ese pueblo comenzó su política expansiva y de conquista.

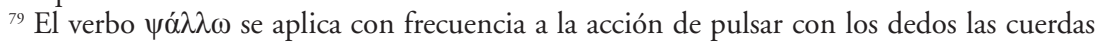
de un instrumento, sin percutirlas con plectro alguno. En ocasiones equivale a «tocar la lira».

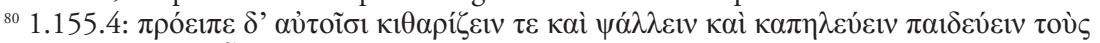

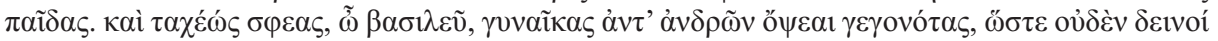

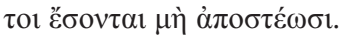

${ }^{81}$ Tocar la cítara se asoció pronto con la mujer: cf. Nicolao historiador, FHG, Fr. 10.72; un texto importante nos lo ofrece Dión Casio, 62.6.3, cuando presenta a Nerón con nombre de varón, pero ocupaciones femeninas.

${ }^{82}$ Véase la secuencia recogida en nota 70. 
estúpido», señala propiamente al «que no aprende», «que no sabe». Está registrado desde el siglo v: Cratino (1), Esquilo (1), Demócrito (3), Heródoto, Tucídides, Eurípides (15), Arquipo (1), Aristófanes (11), Tratados hipocráticos (3), etc., lo conocen bien. En el IV destacan Isócrates (6), Jenofonte (6) y, sobre todo, Platón (63).

9.1. En el primer ejemplo, el calificativo, según indica el historiador, se lo aplica Creso nada menos que a Solón, uno de los siete sabios griegos, una vez que el ateniense le hubiese contestado a su pregunta de si lo consideraba feliz: «Diciendo estas palabras no agradaba en modo alguno a Creso: sin hacerle ningún caso lo despide, pensando en sumo grado que era un ignorante, quien, dejando a un lado los bienes presentes, le exhortaba a mirar el final de cualquier asunto» ${ }^{83}$.

9.2. Si en el texto anterior estamos ante una evaluación mental de Creso, en la secuencia siguiente hallamos una consideración personal del autor: «Y el Ponto Euxino, hacia el cual Darío iba a dirigir su campaña, ofrece los pueblos más ignorantes de todas las tierras, salvo el escita. Pues ni tenemos ningún pueblo de los de dentro del Ponto que sobresalga en sabiduría ni sabemos que haya existido ningún varón notable, excepto el pueblo escita y Anacarsis ${ }^{84}{ }^{85}$.

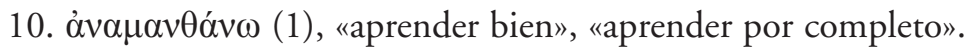

Verbo de uso raro, sólo lo registra el halicarnaseo en el siglo V, donde lo encontramos como una innovación. Posteriormente lo hallamos en Diodoro (1), Filón (1),

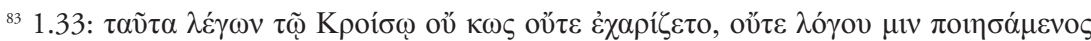

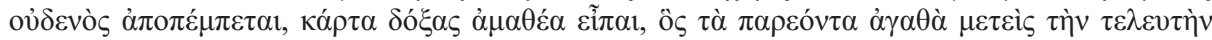

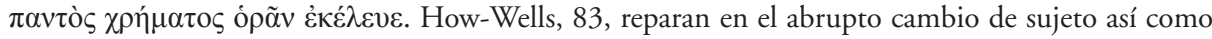
en la falta de correspondencia sintáctica que cabría esperar por la presencia de oű $\tau \varepsilon$... oű $\tau \varepsilon$.

${ }^{84}$ El prosista explicará más adelante (4.76-77) que el citado escita, tras haber estado en muchos países y mostrado su sabiduría en todas partes, fue muerto de un flechazo al tratar de introducir en Escitia costumbres y ritos extranjeros. En efecto, habiendo visto en Cícico una fiesta en honor de la diosa Cíbele, quiso llevar a su patria los rituales pertinentes. A propósito de la presentación del extranjero en Heródoto, véase Hartog-Lloyd, 1988.

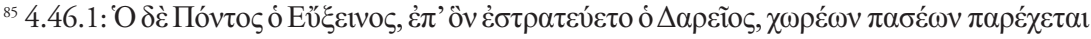

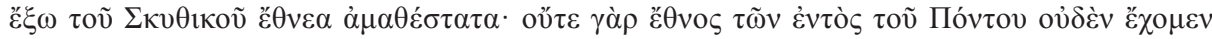

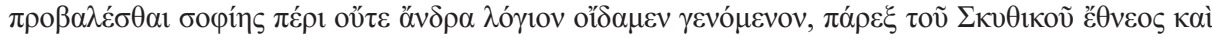
Av $\alpha \chi \alpha ́$ pбıı̧. El pasaje es recogido y parafraseado en Eustacio, Commentarium in Dionysii Periegetae orbis descriptionem, 669.30, a propósito del personaje citado, como hombre «sobresaliente» (ג่vì

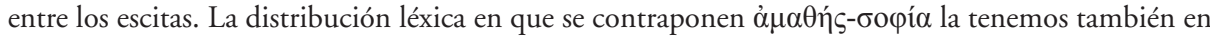
Aristófanes, Nu. 491-2, Platón, Ap. 22e, Smp. 202a; etc. Mucho más frecuente es la oposición polar entre $\dot{\alpha} \mu \alpha \theta i ́ \alpha-\sigma o \varphi i ́ \alpha$, a partir del siglo IV: Jenofonte, Mem. 4.2.22; Platón, Ap. 22e; Tht. 170b; etc. Corcella (Asheri, 615) indica que es típico de la etnografía antigua aplicar superlativos a los pueblos más inteligentes, o los más torpes, así como atribuirlos a sus usos y costumbres. En torno a Anacarsis, especialmente en Heródoto, acúdase a Schubert, 2010. 
Josefo (1), etc ${ }^{86}$. El historiador, refiriéndose a los griegos, está hablando de que la batalla de Platea había tenido lugar por la mañana del mismo día en que, por la tarde, ocurrió la de Mícala: «Y que acontecía que habían tenido lugar en el mismo día y el mismo mes, les resultó claro, no mucho tiempo después, cuando lo aprendieron bien ${ }^{87}$.

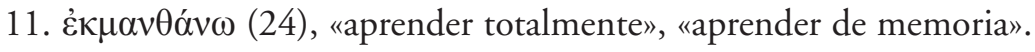

El preverbio غ̇K- tiene, entre sus valores, el de acabamiento o terminación de la acción verbal, es decir, un matiz confectivo ${ }^{88}$. El verbo que revisamos aparece en el siglo v: Esquilo (7), Píndaro (1), Heródoto, Sófocles (21), Eurípides (16), Aristófanes (3), etc., lo utilizan en esa centuria. Entre los prosistas posteriores destacan Plutarco (14), Luciano (14) y Galeno (130). Recogeré sólo los ejemplos más destacados del historiador, especialmente los relacionados con algún aspecto del aprendizaje.

11.1. Abundan los contextos donde el verbo indicado presenta el valor de «saber bien», «comprobar bien», etc., pero sin rozar el terreno de la educación. Algún ejemplo nos plantea dudas sobre si estamos, o no, en el terreno del aprendizaje, de la enseñanza recibida. Así, cuando Atosa, mientras estaba en la cama con Darío, le aconseja la conveniencia de hacer alguna hazaña, "para que los persas aprendan bien que están gobernados por un varón ${ }^{89}$.

11.2. En tres contextos, al menos, creo que encontramos el valor de «aprender bien", y, de ahí, saber algo perfectamente por haberlo aprendido. Tal sucede cuando Perseo «llegó a Egipto, conociendo bien el nombre de Quemis ${ }^{90{ }^{91}}$, pues tal información se la debía a su madre ${ }^{22}$. En segundo lugar, a propósito de que las heteras

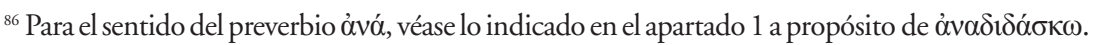

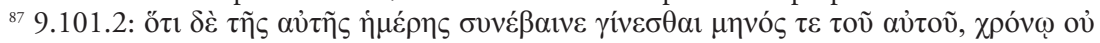

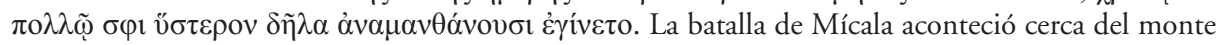
homónimo, situado frente a la isla de Samos.

${ }^{88}$ Chantraine, 1968: 358.

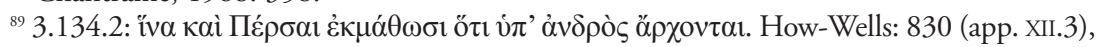
sugieren que el halicarnaseo le da aspectos románticos a una ley no escrita en la historia oriental, a saber, un pueblo conquistador tiene que seguir aspirando a más hasta que sufra una derrota, pues la inactividad significa decadencia. Asheri: 513-519, piensa que el contexto tiene una finalidad etiológica, pues pretende, en suma, buscar la "causa» de las guerras persas; si Helena fue la «causa» de la guerra de Troya, Atosa lo será del expansionismo persa y de las guerras médicas.

${ }^{90}$ Tal ciudad, próxima al Nilo, se llamaría después Panópolis, en el Alto Egipto. En ella se celebraba un culto especial en honor del citado héroe.

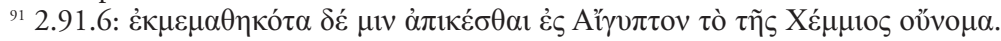

${ }^{92}$ A saber, Dánae. De la presencia de los héroes en Heródoto, así como de la estrecha relación entre mito e historia, véase Vandiver, 1991; en especial, 192-194, para la importancia de Perseo en Quemis, donde, según el historiador (2.93.4-5), los egipcios celebraban juegos a la manera griega. De otra parte, de la integración de relatos míticos en la obra de Heródoto se han ocupado Wesselmann, 2011, y Baragwanath-de Bakker, 2012. 
de Náucratis eran encantadoras, el escritor se extiende en una de ellas, muy conocida, una tracia, compañera de esclavitud de Esopo, la cual, llevada a Egipto a ejercer como prostituta, llegó a ser tan famosa que "todos los griegos habían aprendido bien el nombre de Rodopis ${ }^{33}{ }^{94}$. En una tercera secuencia, hablando del uso de la circuncisión, el historiador señala que sólo era practicada entre los colcos, egipcios y etíopes: «aunque no puedo decir cuáles de los dos, egipcios o etíopes, la aprendieron de los otros, pues parece ser algo antiguo. Pero de que la aprendieron al relacionarse con los egipcios, tengo como gran prueba la siguiente» ${ }^{95}$.

11.3. Ya hemos visto dos textos donde el verbo que estamos revisando está relacionado con $\delta 1 \delta \alpha ́ \sigma \kappa \omega^{96}$ o $\dot{\varepsilon} \kappa \delta 1 \delta \alpha ́ \sigma \kappa \omega^{97}$, y, en ambos casos, a propósito del aprendizaje de la lengua, respectivamente la escita y la griega. Un tercer ejemplo semejante nos lo ofrece el de Halicarnaso cuando afirma: «Los saurómatas utilizan la lengua escita $^{98}$, pero cometen solecismos ${ }^{99}$ con ella desde antiguo, ya que las amazonas no la aprendieron del todo de forma correcta ${ }^{100}$. El historiógrafo afirma en diversos momentos que son las madres, de modo especial, quienes transmiten la lengua a sus hijos. En esta ocasión no comenta ese detalle, pero sí señala que las mujeres

${ }^{93}$ El prosista indica que fue liberada por Caraxo, hermano de Safo (2.135.1), el cual se la llevó consigo a Mitilene. Añade que, cuando llegó con ella a la isla, Safo lo injurió mucho en un poema (2.135.6). Aunque esos versos no nos han llegado, algún autor posterior (Estrabón, 17.1.33) dijo que Rodopis, llamada Dorica por Safo, se había enamorado realmente de Caraxo cuando éste fue a Náucratis a vender vino lesbio.

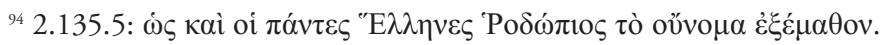

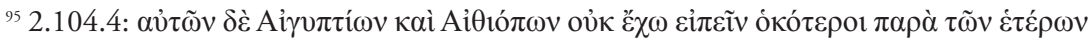

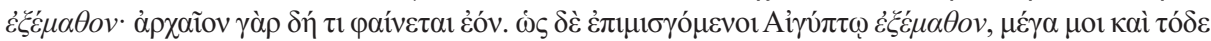
$\tau \varepsilon \kappa \mu \eta ́ p 10 v ~ \gamma i ́ v \varepsilon \tau \alpha 1$. Por cierto, no resulta clara la prueba aportada por el escritor, a saber, que cuantos fenicios comerciaban con Grecia no seguían la costumbre egipcia y ya no circuncidaban a sus hijos. Nótese la convergencia léxica, marcada en cursiva.

${ }_{96}$ Véanse los pasajes recogidos en notas 42-43.

${ }^{97}$ Consúltese la secuencia ofrecida en nota 60.

${ }^{98}$ La lengua escita correspondía al grupo de lenguas iranias, o indo-iranias, procedentes del indoeuropeo. Un panorama general lo ofrece Schmitt, 1989. Por su parte, Corcella (Asheri: 660) apoya la afirmación de que los saurómatas usaban un dialecto parecido al escita.

${ }^{99}$ En general, se llama así al uso de una parte de la oración por otra (sustantivo por infinitivo, etc.), a la utilización impropia de un adjetivo en un lugar que no le corresponde, o de un género por otro, o de un caso por otro, o de un adverbio por otro, y también a diversos errores cometidos a causa de diferencias gráficas. Con el sentido que nos interesa lo registran numerosos escritores: Heródoto (1), Demóstenes (1), Aristóteles (6), Epicuro (2), Aristóxeno (1), Crisipo (3), Filóxeno (1), Dionisio de Halicarnaso (1), Estrabón (1), Plutarco (7), Herenio (1), Galeno (13), Luciano (29), Ateneo, etc. Con respecto a diversos términos relacionados con el citado concepto en la obra de Galeno, cf. López Férez, 2015: 263-271.

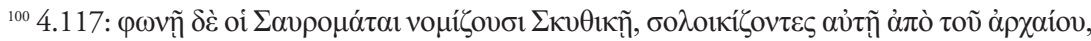

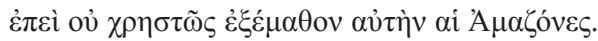


de los saurómatas ${ }^{101}$ descendían de las amazonas, pueblo singular sobre el que ofrece un extenso relato ${ }^{102}$. Así, pues, ni éstas, ni sus hijas (las mujeres de los saurómatas), ni los hijos que las últimas tuvieran de su unión con los citados hablaban bien el escita.

11.4. Por último recojo una secuencia donde se establece una cierta oposi-

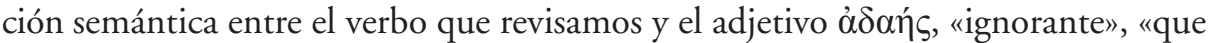
no sabe». Nuestro hombre, hablando de los lacedemonios, afirma:

E, incluso, además de esos detalles, les impulsaban los oráculos ${ }^{103}$ cuando decían que les ocurrirían muchas situaciones hostiles de parte de los atenienses; y de aquéllos eran ignorantes antes, pero, entonces, los aprendieron bien por haberlos traído Cleómenes a Esparta. Cleómenes, desde la Acrópolis de Atenas, había adquirido los oráculos, los cuales los habían adquirido antes los Pisistrátidas, pero, al ser expulsados, los dejaron en el santuario, y, al estar abandonados allí, Cleómenes los había cogido ${ }^{104}$.

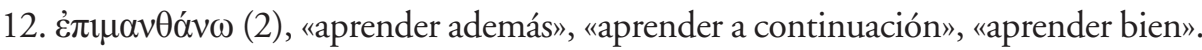

Verbo bastante raro en griego: el TLG sólo recoge 27 usos. Es otra innovación léxica del escritor. En los siglos V-IV lo encontramos tan sólo en cuatro ocasiones:

${ }^{101}$ Los saurómatas, un pueblo de estirpe irania, vida nómada y economía básicamente pastoril, procedían de Asia Central y fueron conocidos posteriormente con el nombre de sármatas; ocupaban el territorio que iba desde la margen izquierda del Don hasta el Volga, más arriba de Volgogrado: Cf. Schrader: IV, 300.

102 4.110-117: cómo llegaron por mar cerca del territorio escita, al norte del mar de Azov, y lo saqueaban a caballo; cómo los escitas decidieron tener hijos con ellas y luego se les unieron sexualmente; los problemas mutuos con el uso de sus lenguas; ellas aprendieron antes; luego, convencieron a los escitas para atravesar el Tanais y se establecieron a tres días de camino de ese río en dirección este, donde entonces, en la época del historiador, residían; etc. Cabe suponer que Heródoto relata hechos de su propia época, cuando los saurómatas estaban casados con mujeres procedentes, según él, de las antiguas amazonas. Sobre éstas, véase más información en la nota 141.

${ }^{103}$ Macan: I, 234, indica que esos oráculos no tenían carácter délfico. Por lo demás, del pasaje se deduce que, ya en la época de los Pisistrátidas (527-510 a. C.), Atenas había comenzado la política de hostilidad y amenaza contra Lacedemonia. Cabe inferir que los tiranos atenienses habían tenido un poder importante sobre el contenido de los oráculos. Las amenazas atenienses contra Lacedemonia acabaron cuando Cleómenes, rey de Esparta, se llevó los oráculos que había en el templo de Atenea Poliade, sito en la Acrópolis. Poco después, aproximadamente en el 500 a. C., según nos dice el de Halicarnaso (5.91.2), los espartiatas quisieron reponer a Hipias como tirano de Atenas, afirmando que, por causa de unos oráculos, se habían equivocado al haber expulsado anteriormente de dicha ciudad a toda la familia. Los oráculos de carácter político se hicieron muy frecuentes en Grecia desde mediados del siglo VI a. C. (cf. Heródoto, 8.141.1, y Tucídides, 2.8.2). Previamente, los Alcmeónidas, con Clístenes a la cabeza, habían sobornado el oráculo de Delfos para que convenciera a Cleómenes a fin de derrocar a los Pisistrátidas, hecho acontecido en el 510 a. C.

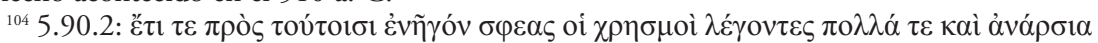

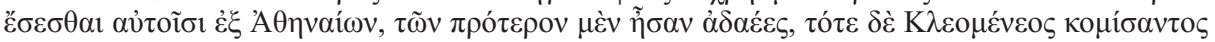

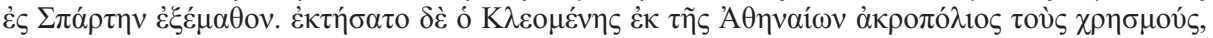

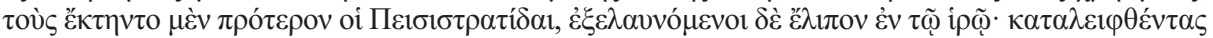

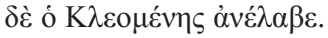


Heródoto (2), Tucídides (1), Jenofonte (1). Mucho después, destaca Galeno (12). El sentido roza el campo de la educación, en la medida en que el sujeto de la acción verbal está dispuesto a aprender algo. Veamos los dos ejemplos.

12.1. El historiador explica que entre las costumbres de los persas está hacer sacrificios en honor de Zeus, el sol, la luna, tierra, agua, fuego y vientos ${ }^{105}$. Y, en tal contexto, precisa lo siguiente: «A ésos solos les hacen sacrificios desde el comienzo, pero han aprendido también a sacrificar en honor de Urania ${ }^{106}$, tras haberlo aprendido de los asirios ${ }^{107}$ y árabes ${ }^{108}{ }^{109}$.

12.2. Unos representantes de los eleos llegaron ante Psamis ${ }^{110}$, convencidos de que las reglas de la competición de Olimpia eran las mejores: «Tras haberlo explicado todo, afirmaron que habían venido para aprender bien si los egipcios podrían encontrar algo más justo que eso» ${ }^{111}$.

13. $\mu \alpha \dot{\theta} \theta \eta \mu \alpha(1)$, «aprendizaje, conocimiento, estudio».

Es uno más de los numerosos neutros en $-\mu \alpha,-\mu \alpha \tau o \zeta$, que indican, especialmente, el resultado de la acción: la filosofía hizo gran uso de ellos ${ }^{112}$. El que ahora

${ }^{105}$ He aquí una versión ampliada de la teoría de los cuatro elementos, con la novedad de que se habla de los vientos en vez del aire.

${ }^{106}$ Entiéndase Afrodita. El escritor aprovecha la ocasión para dar la equivalencia lingüística del término en asirio, árabe y persa, aunque comete algún error de bulto, como confundir el dios Mitra con una divinidad femenina. How-Wells, 128, señalan la estrecha conexión de la diosa griega con la babilonia Milita, la asiria Istar y la fenicia Astarté, si bien pudieron ser desarrollos independientes en las respectivas culturas. Por lo demás, sabemos bien que Platón (Smp. 180-181) establece claramente la distinción entre Afrodita Urania (la Celeste y pura) y la Pandemo, la popular. Véase, asimismo, Jenofonte, Smp. 8.9. En todo caso el halicarnaseo es el primero en mencionarla con ese apelativo.

${ }^{107}$ Heródoto (32) y Tucídides (1) son los primeros en nombrarlos. Posteriormente, destacará Jenofonte (91). Tanto este gentilicio como el siguiente son sendas innovaciones herodoteas.

${ }^{108}$ Heródoto (42) es pionero en citarlos. Asheri, 167, puntualiza que los Apáßror de Heródoto son los "A $\alpha \beta \varepsilon \varsigma$ de que hablan fuentes posteriores.

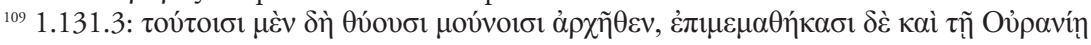

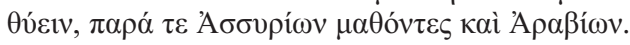

${ }^{110}$ Psamético II (594-588 a. C.). El de Halicarnaso (2.160.1) afirma que reinó en Egipto sólo seis años y llevó a cabo una campaña contra Etiopía. El episodio de los eleos lo presenta Diodoro (1.95) como acontecido en los años del faraón Amasis (=Amasis II, 570-526 a. C.).

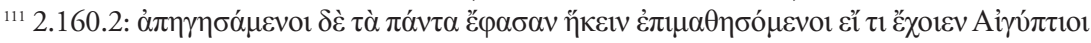

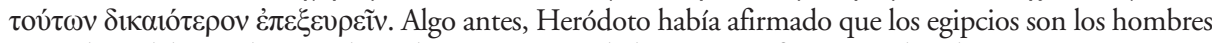
más sabios del mundo. Pues bien, la contestación de los egipcios fue que, si los eleos querían organizar una competición verdaderamente justa, habían de excluir a sus conciudadanos, a fin de no favorecerlos en detrimento de los extranjeros. Asheri: 360, se ocupa de un tema recurrente en la Antigüedad: la sabiduría de los egipcios.

${ }^{112}$ Cf. Schwyzer: I, 522-524. 
estudiamos aparece en el siglo V. En Heródoto, Eurípides ${ }^{13}$ y Sófocles ${ }^{114}$ lo leemos con el valor de "lo ya aprendido», «lección», es decir, algo conseguido, pasivo; pero, en otros autores tiene otro matiz, «aprendizaje, conocimiento, estudio», con un sentido claramente activo: tal sucede en Tucídides, como veremos. Con este último significado lo ofrecen, en el siglo IV, Isócrates y Platón, quien también recoge el primer sentido.

El autor ofrece el primer valor a que nos hemos referido y, casi con seguridad, es otra innovación léxica, pues su obra es quizá algo anterior a las de los dos trágicos antes indicados, donde el término aparece. El vocablo lo leemos en Heródoto cuando, indeciso Ciro entre atacar o no a Tomiris, reina de los maságetas, y aconsejándole muchos que esperara el ataque de los enemigos en el lugar donde se encontraba, Creso, manteniendo la opinión contraria, la de cruzar el río Araxes y atacarlos, le dijo entre otros puntos: «Mis padecimientos, al ser infortunados, han llegado a ser lecciones $»^{115}$. Dichas palabras contienen un pensamiento paralelo al que fuera expresado antes por Esquilo ${ }^{116}$.

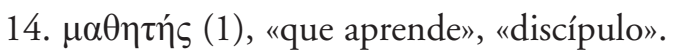

Entre los autores de obra conservada son Heródoto (otra innovación léxica) y Aristófanes (7) ${ }^{117}$ los primeros en atestiguarlo. En la centuria siguiente, Platón sobresale por el número de secuencias (49) y matices. En el historiógrafo lo hallamos en un contexto donde se nos cuenta cómo los escitas le quitaron la vida a Anacarsis por tratar de introducir en su tierra ritos extranjeros. El de Halicarnaso ofrece varias versiones de lo acaecido: «Ahora bien, también he oído un relato diferente contado por los lacedemonios: que Anacarsis, enviado por el rey de los escitas para que fuera discípulo de la Hélade, una vez regresado a su procedencia, afirmó, ante quien le había enviado, que todos los griegos estaban dedicados a la sabiduría de

${ }^{113}$ Hec. 814. Obra del 424 a. C.

${ }^{114}$ Ph. 918. La pieza fue representada en el 409. Para la publicación de la Historíe, véase nota 4 .

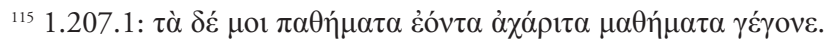

${ }^{116} \mathrm{El}$ estrecho paralelo y correspondencia mutua entre el sufrimiento y el aprender es semejante al que en fechas anteriores leemos en el Agamenón, donde el Coro de ancianos habla de Zeus:

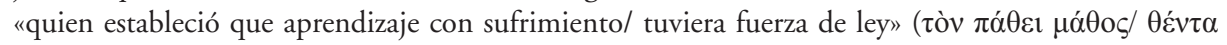

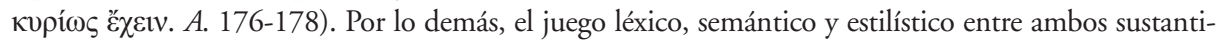
vos lo hallamos también en Jenofonte (Cyr. 3.1.17), y lo recoge, mucho después, Galeno (4.673.14).

${ }^{117}$ En $N u .(133,140,142,502,1413,1497)$ y $R$. (964), comedias, respectivamente, de 423 y 405 a. C. 
toda clase, salvo los lacedemonios, pero sólo con éstos se daba y recibía conversación de modo sensato» ${ }^{118}$.

Advertimos en la distribución sintáctica el genitivo de procedencia, con el que se apunta a la persona de quien se aprende algo como discípulo, construcción corriente en Platón ${ }^{119}$.

\section{5. $\mu \alpha v \theta \alpha ́ v \omega ~(149)$, «aprender».}

Este verbo lo encontramos ya en Homero (3). En los textos más antiguos empieza a ser utilizado con el valor de «aprender por la práctica, por la experiencia», «aprender a hacer», «aprender a conocer». De ahí pasó a la noción de "comprender» ${ }^{120}$. En el siglo V lo tenemos en Píndaro (10), los tres trágicos (Esquilo, 52; Sófocles, 98; Eurípides, 129), Heródoto, etc. En la centuria siguiente destaca Platón (648).

Antes de abordar el sentido de «aprender» algo de otro, con lo que estaremos en el campo de la educación, entendido en sentido amplio, veamos una secuencia, entre muchas, donde nos acercamos a ese valor. Así lo tenemos en las palabras de Darío a su mujer, partidaria, ante todo, de apoderarse de Grecia: «Mujer, pues realmente te parece que nosotros nos apoderemos ante todo de Grecia, me parece, en primer lugar, que lo primero es enviar hasta ellos exploradores persas junto con ese que tú dices, los cuales, tras aprender y ver, nos cuenten cada cosa respecto a ellos» ${ }^{121}$.

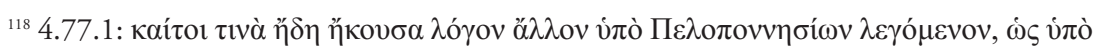

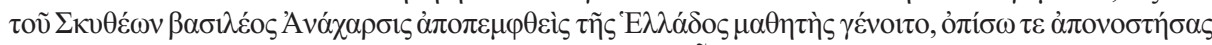

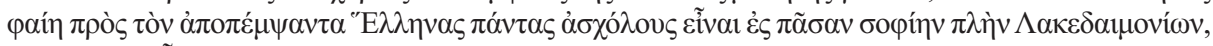

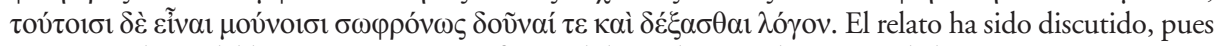
parece un elogio del laconismo espartano frente al deseo de aprender propio de los jonios. Macan, I, 52, recoge varias interpretaciones y cree que la verdadera intención de la secuencia es elogiar la "prudencia» y la «sabiduría» de los peloponesios, con lo que la frase más delicada ( $\alpha \sigma \chi 0 ́ \lambda$ ov cìv $\alpha$ l) cabría entenderla en el sentido de que todos los helenos «no tenían tiempo libre» (sc. para dedicarse a la sabiduría), salvo los peloponesios. Por lo demás, de la íntima relación «griegos»-«sabiduría» tenemos abundantes ejemplos en la literatura griega. Recojo unos pocos: Píndaro, O. 1.16; Heródoto, 1.60.3; Platón, Prt. 342b; Dionisio de Halicarnaso, Isoc. 1(bis); etc. Corcella (Asheri, 637) examina el pasaje y subraya que el relato de los peloponesios se centra, no en apreciar el carácter filohelénico de Anacarsis, sino en destacar el laconismo espartano.

${ }^{119}$ Cf. «discípulo de alguno» (Phd. 99c); «discípulo de nadie respecto a tales cosas» (Lach. 186e); «alumno de Eros» (Smp. 197b); «Damón, discípulo de Agatocles» (Lach. 180d); «de entre los discípulos de Protágoras» (Prt. 315a); etc.

${ }^{120}$ Véase, Chantraine, 1968: 664. Además, Dörrie, 1956, aporta numerosos ejemplos referentes al paralelo y contraste entre $\pi \alpha \theta \varepsilon \tilde{v} v-\mu \alpha \theta \varepsilon \tilde{v}$. Sobre $\mu \alpha v \theta \alpha ́ v \omega$ y sus compuestos es importante el trabajo de Douterelo, 2001. En general, para dicho verbo y su familia léxica, aporta es relevante el estudio de Coray, 1993.

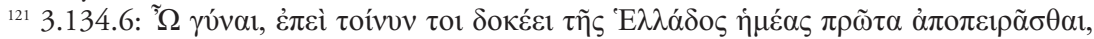

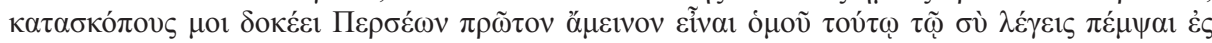

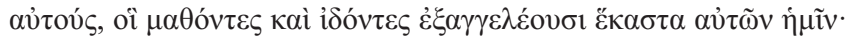


Nótese que la acción de «aprender» ( $\mu \alpha \theta$ óv $\tau \varepsilon \varsigma$ ) ocupa en el texto un lugar anterior

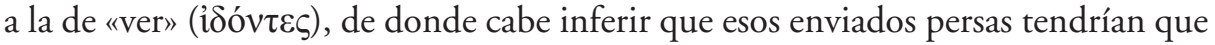
recabar una serie de informaciones mediante confidentes o preguntando a las gentes de su confianza antes de observar la realidad por sus propios ojos.

Dentro de nuestro historiador, me centraré ahora en los ejemplos donde haya algún elemento que nos permita pensar que estamos ante el significado de «aprender» y, por tanto, dentro del amplio campo de la educación. Hallamos un esquema que se repite en numerosos pasajes: alguien aprende algo de otro. Es un asunto interesante que no le pasó inadvertido a un gran viajero, observador y estudioso como Heródoto. En la exposición de los ejemplos seguiremos un cierto orden histórico.

15.1. Comenzamos con lo que aprendieron los griegos de otros pueblos.

15.1.1. Primero, de los pelasgos. Sabemos que los griegos (o quizá mejor: los hablantes de griego), al llegar a Grecia, se encontraron con los pelasgos, pueblo del que el escritor se ocupó en numerosos pasajes ${ }^{122}$. Precisamente, Heródoto sostiene que los griegos habían adoptado numerosas costumbres a partir de los egipcios, "pero hacen las estatuas de Hermes con el miembro erecto, no por haberlo aprendido de los egipcios, sino tras haberlo tomado los atenienses, los primeros de los griegos, a partir de los pelasgos ${ }^{123}$, y, a partir de aquéllos, los demás» ${ }^{124}$.

15.1.2. En segundo lugar, de los babilonios: «Pues el polo, el gnomon y las doce partes del día los aprendieron los griegos a partir de los babilonios» ${ }^{125}$.

15.1.3. A continuación, vendrían quizá los fenicios. Se trata ahora de otro tipo de aprendizaje, a saber, el préstamo lingüístico, referido, en concreto, al nombre de

${ }^{122}$ Véase nota 41.

${ }^{123}$ How-Wells: 213, apuntan que se trataría aquí, no de los primeros habitantes de Grecia, sino de una colonia pelasga establecida en el Ática (cf. Hdt., 1.57.2)

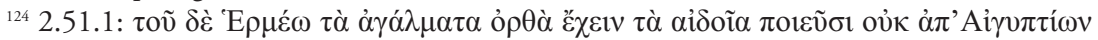

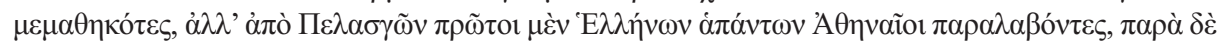

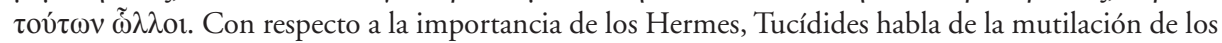
mismos en Atenas, pues en una sola noche les cortaron a casi todos la cabeza (6.27.1), lo que produjo una consternación general y un sentimiento popular contra lo que se entendió como una señal para derrocar la democracia. Por su lado, Pausanias (4.33.4) insiste en que los demás griegos tomaron de los atenienses la costumbre de representar al dios de ese modo. Lloyd (Asheri: 273) observa que Heródoto ofrece dos tradiciones diferentes sobre la historia del Ática: según una (8.44.2), los atenienses fueron pelasgos transformados en helenos; según la otra (6.137.1-4), los pelasgos vivieron en el Ática al lado de los atenienses. Ahora bien, el texto presente es una mezcla de ambas tradiciones.

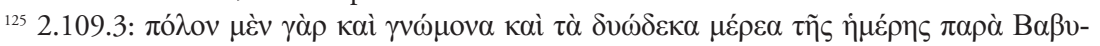
$\lambda \omega v i ́ \omega v$ ع̌ $\mu \alpha \theta$ ov oi "E $\mathrm{A} \lambda \eta v \varepsilon \varsigma$. El polo, una especie de reloj de sol hemisférico, construido a semejanza de la bóveda celeste, se utilizaba para seguir la traslación del sol. En el citado, destacaba el gnomon, un puntero que indicaba el momento del día según la dirección que tenía. El espacio situado entre la salida y puesta del sol era dividido en doce partes, cuya duración dependía de la época del año. Según Diógenes Laercio (2.1), Anaximandro puso en Lacedemonia el primer gnomon. 
una planta: "Y dicen que unas aves grandes transportan esas ramas secas a las que nosotros, tras haberlo aprendido de los fenicios, llamamos cinamomo» ${ }^{126}$.

15.1.4. Después nos fijamos en los contactos con los egipcios: «Los egipcios fueron los primeros entre los hombres en celebrar asambleas generales, procesiones y ceremonias sagradas ${ }^{127}$, y a partir de ésos las han aprendido los griegos» ${ }^{128}$.

15.1.5. Por último, los libios: «Y los griegos han aprendido de los libios a uncir cuatro caballos» ${ }^{129}$.

15.2. Pueblos que aprenden de los griegos algún asunto. Heródoto explica que los persas son los hombres más propensos a adoptar las costumbres extranjeras: «Y, cuando se informan de placeres de todo tipo, los practican, y, así, tras haberlo aprendido de los griegos, se unen ${ }^{130}$ con niños» ${ }^{131}$.

15.3. Unos pueblos (no griegos) aprenden de los egipcios: «Los demás (sc. pueblos) dejan las partes sexuales como ellos han nacido, salvo cuantos han aprendido de ésos (sc. los egipcios), pero los egipcios se circuncidan»" ${ }^{132}$; "[.. . los etíopes, habiendo aprendido las costumbres egipcias, han llegado a ser bastante civilizados» ${ }^{133}$.

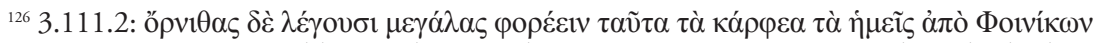

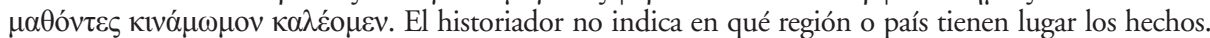
Con respecto al cinamomo, Teofrasto (HP 9.4.5) habla de varias clases, indicando que solía comerciarse en rama. Varios indicios del contexto (lugares relacionados con la crianza de Dioniso, intervención de esas aves misteriosas) hacen pensar que el relato herodoteo puede estar basado en un cuento popular.

${ }^{127}$ How-Wells: 216, recogen varios sentidos para el término $\pi$ o $\mu \pi \eta ́$, pues para unos es la acción mediante la cual la imagen de una deidad visita a otra divinidad ( $\pi \rho 0 \sigma \alpha \gamma \omega \gamma \eta ́)$; para otros, alude a la procesión hacia el templo, acompañada de sacrificios. Por su lado, Sayce, 159, piensa en las letanías e himnos cantados siguiendo la música de algunos instrumentos.

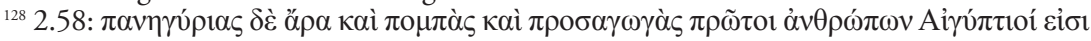

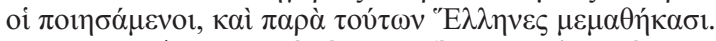

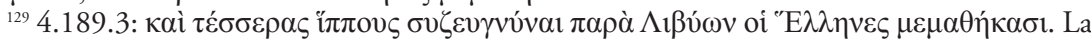
afirmación del prosista está en contradicción con Homero (Il. 11.699; Od. 13.81), Galeno (4.361.16), y, especialmente, Pausanias (5.8.7), el cual sitúa en 680 a. C. la primera victoria olímpica en la carrera de carros. Por su lado, Corcella (Asheri: 712) señala que aparecen cuadrigas en las representaciones geométricas del viII a. C.

${ }^{130}$ Dentro de las expresiones eufemísticas referidas a la unión sexual, las construidas con el verbo $\mu$ í $\gamma v \mu \mu / \mu \varepsilon i ́ \gamma v v \mu$ ( (en la voz media, «unirse»; propiamente, «mezclarse») son de las más usadas en griego. Algunos ejemplos: Homero (Il. 6.25; O. 7.61), Píndaro (O. 6.29; 7.71); Eurípides (Andr. 174; Io. 338); etc.

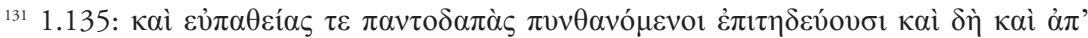

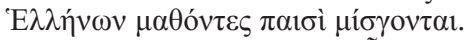

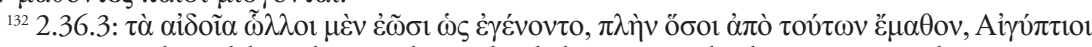
$\delta \varepsilon \grave{\varepsilon} \pi \varepsilon \rho \tau \alpha \dot{\mu} \mu v o v \tau \alpha$. De las palabras de Heródoto cabe deducir que todos los egipcios estaban circuncidados. Josefo (Ap. 2.13), en cambio, sostiene que sólo los sacerdotes tenían dicha condición. En todo caso, frente a lo que leeremos en 2.104.3-105 (nota 140), había otros pueblos semíticos, o no, que practicaban la circuncisión por motivos religiosos, y, quizá, también sanitarios: cf. How-Wells: 202.

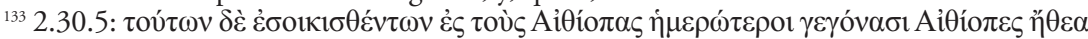

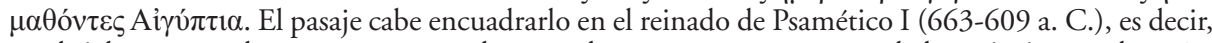
en el siglo VII, pero hay numerosas pruebas que documentan un contacto de los egipcios con los etíopes ya en la XII Dinastía (1991-1802 a. C.), cuando los faraones se apoderaron de parte de Etiopía, extendiendo sus dominios hasta la segunda catarata: véase How-Wells: 196. 
15.4. Unos pueblos (no griegos) aprenden de otros (no griegos). El escritor se ocupó repetidas veces de la circuncisión, en la que vio una costumbre relevante de ciertos pueblos:

Pues los fenicios y los sirios de Palestina, y ellos mismos lo reconocen, lo han aprendido de los egipcios, pero los sirios de en torno al río Termodonte ${ }^{134} \mathrm{y}$ el Partenio ${ }^{135}$, y los macrones ${ }^{136}$, que son vecinos de ésos, afirman que lo han aprendido recientemente de los $\operatorname{colcos}^{137}$, pues ésos ${ }^{138}$ son los únicos entre los hombres que se circuncidan, y es evidente que ésos lo hacen del mismo modo que los egipcios. De entre los propios egipcios y etíopes no puedo decir cuál de los dos lo aprendió del otro, pues realmente es algo antiguo. $Y$ de que lo aprendieron ${ }^{139}$ al mezclarse con Egipto, tengo como gran prueba la siguiente: cuantos fenicios se mezclan con Grecia ya no imitan a los egipcios en lo referente a las partes sexuales, sino que no circuncidan los miembros de aquellos que les van naciendo ${ }^{140}$.

15.5. Algunos pasajes nos muestran las dificultades para aprender algo de otros, concretamente una lengua extranjera. Así sucede en la secuencia en que los escitas,

${ }^{134}$ Hoy, Terme Thsai. Pequeño río de la provincia turca de Samsun; desemboca en el Mar Negro.

${ }^{135}$ Llamado, actualmente, Bartin Thsai. El río nace en los Montes Ilgaz y termina también en el Mar Negro.

${ }^{136}$ Los macrones, antigua tribu emparentada con los colcos, vivían al este del Mar Negro. Heródoto es el primero que los menciona (4); luego, Jenofonte (9).

${ }^{137}$ Las primeras menciones de los colcos las hallamos en Píndaro (3), Heródoto (16), Sófocles (1) y Eurípides (2). Eran los habitantes de la Cólquide, patria de Medea, territorio situado junto al extremo oriental del Mar Negro.

${ }^{138}$ Creo que oṽ̃ol recoge anafóricamente a todos los pueblos mencionados que practican la circuncisión. How-Wells, 241, aportan la explicación de algunos estudiosos según los cuales hubo una dependencia directa de los colcos con respecto a los egipcios. En este sentido, se ha sugerido, incluso, una deportación de egipcios al territorio de la Cólquide.

${ }^{139}$ Como en tantas otras ocasiones sucede en el historiador, no está claro quién es el sujeto del verbo. Creo que son todos los pueblos que habían aprendido de los egipcios la citada práctica, no sólo los etíopes, los últimos mencionados, pues habría un contrasentido al referirse a continuación a los fenicios, que no tenían vínculo alguno con los etíopes.

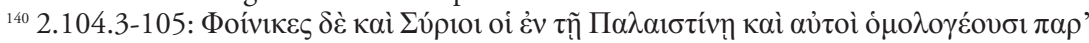

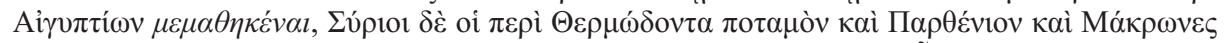

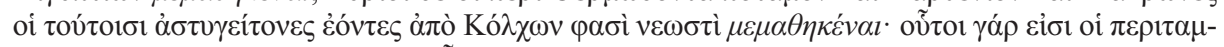

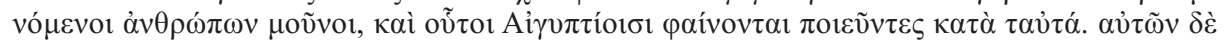

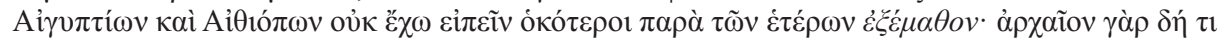

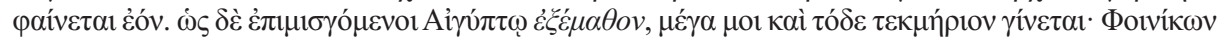

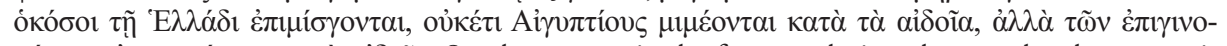

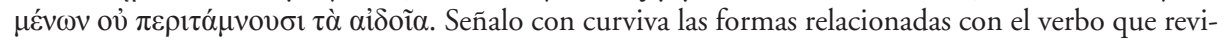
samos o con un compuesto, evidente ejemplo de acumulación léxica, cuyo objetivo aquí es recalcar la idea de «aprender», esencial en el párrafo. Lloyd (Asheri: 315) sostiene, en cambio, que la circuncisión entre los pueblos semitas no tiene un origen egipcio. 
enviados para acampar junto a las amazonas ${ }^{141}$, se encontraron con ellas. En un primer momento ninguno de los dos grupos entendía al otro, pero una amazona que se había unido voluntariamente con un escita, le hacía saber por señas, hechas con la mano

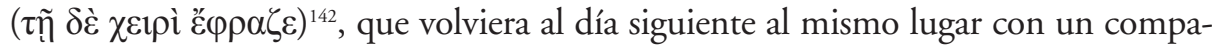
ñero; así lo hicieron, y posteriormente todos los jóvenes escitas se unieron con igual número de amazonas: «Después, tras haber unido sus campamentos, vivían en común, teniendo cada uno la mujer con la que se había unido al comienzo. Los varones no podían aprender la lengua de las mujeres, pero las mujeres comprendían la de los varones. Y cuando se entendieron mutuamente, los varones les dijeron a las amazonas lo que sigue» ${ }^{143}$.

15.6. Los griegos aprenden de una persona concreta: «Habiendo introducido Melampo $^{144}$ que el falo fuera llevado en procesión en honor de Dioniso, los griegos, tras aprenderlo de ése, realizan lo que realizan ${ }^{145}{ }^{146}$.

${ }^{141}$ Este pueblo mítico es recogido por numerosos escritores antiguos. Menciono algunos hasta el siglo IV: Homero (2), Etiópide (1), Esquilo (4), Heródoto (13), Eurípides (6), Isócrates (5), etc. En el terreno del mito las amazonas están ligadas fundamentalmente a Heracles, que hizo una expedición contra ellas, acompañado de Teseo, para apoderse del cinturón de Hipólita, la que luego, unida al héroe ateniense, sería madre de Hipólito. Vencidas por Heracles, las amazonas atacaron Atenas, una de cuyas grandes glorias habría sido derrotarlas en su intento de apoderarse de la Acrópolis, motivo dilecto de literatos y artistas diversos. Una reina de las amazonas fue Pentesilea (hermana de Hipólita), que intervino en la guerra de Troya y es citada por primera vez en el poema cíclico Etiópida de Arctino de Mileto. El lugar de residencia de ese pueblo mítico varía según los autores: Homero (Licia), Heródoto (Escitia), Diodoro de Sicilia (Libia), Estrabón (junto al río Termodonte), etc. Nada sabemos de su lengua, pues ni siquiera está bien establecido el significado del gentilicio: Cf. Chantraine, 1968: 69, donde, con dudas, y, descartando la etimología popular («sin seno»), se propone como origen el nombre de una tribu irania: * ha-mazan, "guerreros».

${ }^{142}$ 4.113.2. Una expresión semejante hallamos, por primera vez, en Esquilo, $A$. 1061, cuando Clitemnestra le pide a Casandra que, si no comprende lo que le está diciendo, le replique, en vez de con la palabra, con signos hechos con su mano bárbara. Sobre la importancia de los signos y su interpretación dentro de la obra herodotea, véase Hollmann, 2011.

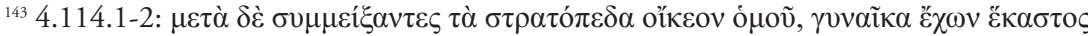

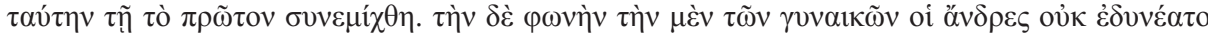

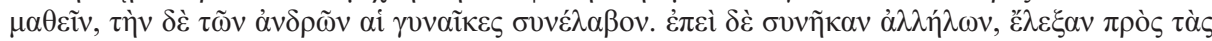

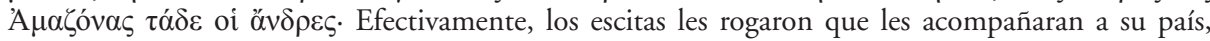
donde tenían padres y propiedades, y, al mismo tiempo, les prometieron que las harían sus esposas.

${ }^{144}$ Héroe de Pilos (Mesenia), fue quizá el primer adivino, médico y taumaturgo, así como el primero que erigió un templo en Grecia en honor de Dioniso. Cf. Schrader: II, 337. De la presencia de aquél en la Historia herodotea se ocupa Gray, 2012.

${ }^{145}$ Expresión eufemística con que se alude a las ceremonias obscenas realizadas durante ciertos rituales dionisiacos: Cf. Heráclito, B 15.

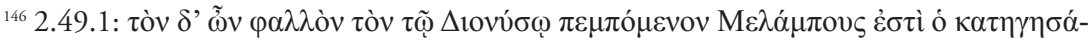

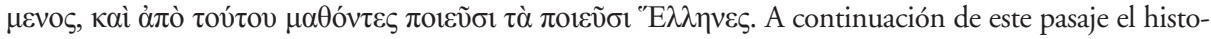
riador nos ilustra sobre otros muchos asuntos que Melampo aprendió en Egipto. Cita, por ejemplo, las ceremonias referentes a Dioniso. 
15.7. Una persona concreta aprende algo de otros pueblos: «Dicen que, tras haber llegado los escitas para eso, Cleómenes tuvo con ellos un trato mayor de lo normal, y al tratarlos más de lo apropiado, aprendió de ellos a beber vino puro. Y los espartiatas piensan que por eso se volvió loco» ${ }^{147}$.

15.8. En ocasiones, el de Halicarnaso no sabe bien de quiénes han aprendido algo ciertos pueblos:

Pues bien, si los griegos han aprendido eso ${ }^{148}$ de los egipcios, no puedo juzgarlo con precisión, al ver que también tracios, escitas, persas, lidios y casi todos los bárbaros tienen por menos dignos que a los demás ciudadanos a quienes aprenden las artes ${ }^{149}$ y a los hijos de ésos, y, en cambio, consideran nobles a quienes se apartan de los oficios manuales, $y$, de modo especial, a los que se dedican a la guerra. $Y$ bien, todos los griegos han aprendido eso, ante todo los lacedemonios ${ }^{150}$, pero son los corintios los que menos censuran a los artesanos ${ }^{151}$.

15.9. Frente al sentido positivo del verbo que recorremos, vemos en otro lugar que las amazonas no habían aprendido ciertas actividades consideradas femeninas. Tal leemos cuando aquéllas les replican a los escitas que querían llevárselas

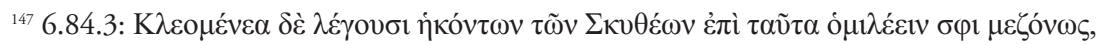

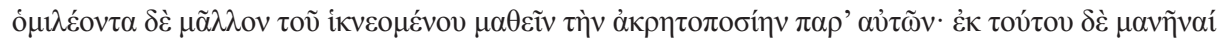

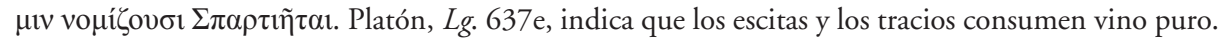
Ateneo, 36b, recuerda que beber vino puro produce parálisis de los cuerpos.

${ }^{148}$ A saber, la costumbre de no permitir ejercer ningún oficio, salvo el arte militar.

${ }^{149}$ Es la primera vez en la literatura griega donde se asocian ambos términos: «aprender»-«artes» (como objeto directo). Otros ejemplos los presentan Aristófanes, Pl. 905, Jenofonte, Mem. 4.2.5, Isócrates, 19.45, Platón, Euthd. 289e; etc.

${ }^{150}$ Entre los lacedemonios estaba prohibido dedicarse a las labores artesanales: cf. Plutarco, Ages. 5. Esas ocupaciones estaban reservadas a los periecos. Aristóteles, hablando de la ciudad ideal, expone que los ciudadanos no deben tener una vida propia de «artesanos» (Pol. 1328b39), afirmando, además, que el «artesano» no participa de la ciudad (1329a20), y recurriendo al ejemplo de Tesalia (1331a34), donde los artesanos y campesinos son excluidos de la plaza pública a no ser que les llame

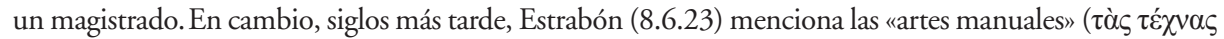

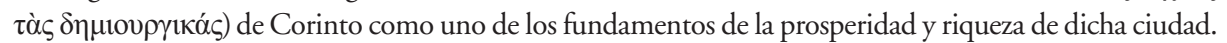

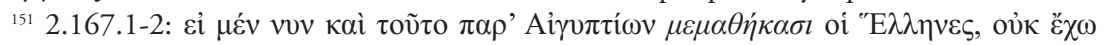

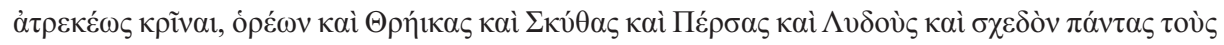

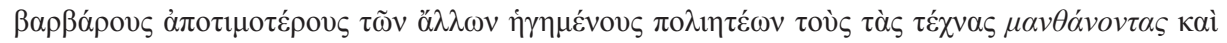

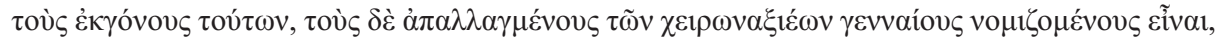

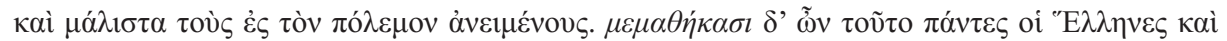

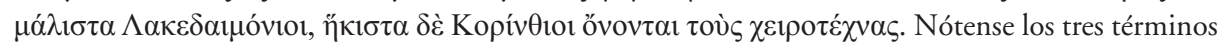
en cursiva: otra acumulación léxica. 
a su tierra y hacerlas sus legítimas esposas: «Nosotras usamos arcos, lanzamos jabalinas y montamos a caballo, pero no hemos aprendido los trabajos femeninos» ${ }^{152}$.

16. $\mu \varepsilon \tau \alpha \mu \alpha \nu \theta \alpha ́ v \omega(1)^{153}$, «aprender después», «aprender de otro modo», o «mejor».

Solamente hallamos dos usos en el siglo V: en Esquilo ${ }^{154}$ y en Heródoto, precisamente en el pasaje que veremos a continuación, pues merece una lectura algo más extensa y detenida de lo normal. El de Halicarnaso reflexiona sobre el interés de Creso por saber cuáles eran los griegos que descollaban entre todos, a saber, los lacedemonios y los atenienses, aquéllos de raza dórica, y éstos de la jónica; los atenienses,

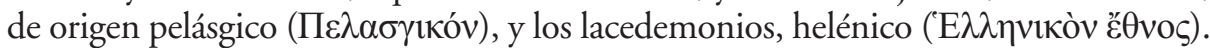
Con ese propósito, indica que si aquéllos no habían cambiado nunca de lugar de residencia, éstos habían viajado mucho. Tras algunas otras consideraciones sobre los cambios de lugar por los que habían pasado los lacedemonios, el historiador, basándose en diversos hechos probados, se ocupa de varios grupos de pelasgos que cambiaron su nombre, y deduce lo siguiente:

Eran los pelasgos, pues hablaban una lengua bárbara. Por tanto, si todo el grupo pelásgico era tal, el pueblo ático, siendo pelásgico, junto con su cambio en helenos, también aprendió después la lengua [...] En cambio, el grupo helénico usa siempre la misma lengua, desde que él llegó a existir, tal como me parece a mí. Siendo débil, con todo, al separarse del pelásgico, partiendo al comienzo desde un número pequeño, crece hasta una gran multitud de pueblos, al agregársele especialmente el pelásgico y otros numerosos pueblos bárbaros. Y, además, me parece que ni siquiera el pueblo pelásgico, por ser bárbaro ${ }^{155}$, aumentó jamás de modo considerable ${ }^{156}$.

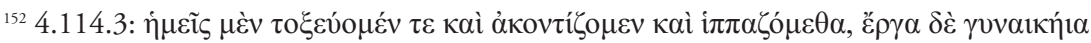

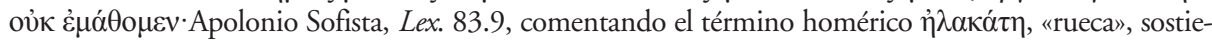
ne que el poeta cree propio del trabajo femenino ese instrumento, apto para trabajar la lana.

${ }_{153}$ Sobre el preverbio $\mu \varepsilon \tau \alpha$-, entre cuyos valores conferidos al verbo simple figuran la noción de tiempo y la de cambio, véase Chantraine, 1968: 689-690.

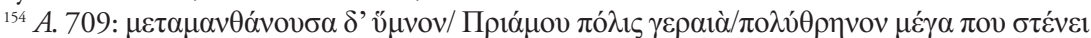
[...] «Mas, aprendiendo después/ la vieja ciudad de Príamo/ un himno de gran lamento,/ gime mucho en alguna ocasión[...]».

${ }^{155}$ De este juicio parecen salvarse los atenienses, pues habían aprendido la lengua griega. Además, por el contenido de la secuencia, se deduce que eran uno de los dos grupos más importantes entre los griegos en la época de Creso. De otra parte el crecimiento, en todos los órdenes, de los atenienses parece haberse debido al aprendizaje de la lengua griega, mientras que el resto de pueblos pelásgicos, al ser bárbaros (es decir, no haber aprendido dicha lengua) experimentó una evolución bastante limitada. Sobre la relación pelasgos-atenienses, véase Lape, 2010, en general, y, en especial 149-154, para el juicio de Heródoto. A propósito del surgimiento y constitución de la "nación ática», acúdase, entre otros, a Cohen, 2000.

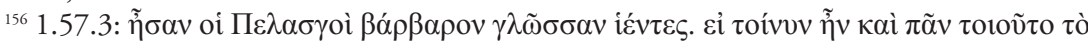

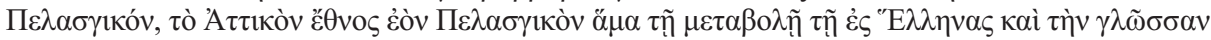




\section{TUCÍDIDES}

Tucídides ${ }^{157}$ dio un paso definitivo en la Historiografía, pues concentró su atención, no en una historia universal, sino en un conflicto contemporáneo en que participó y cuyas consecuencias sufrió personalmente. Se consagró al estudio de las causas y efectos de la confrontación bélica entre los peloponesios y los atenienses junto con sus respectivos aliados, guiado por el mismo espíritu científico que en sus propios años dio nacimiento, entre otras artes, a la Medicina, la Sofística de primera hora y el pensamiento filosófico de Demócrito. Nos atañe un aspecto singular de la lengua ${ }^{158}$ en que están escritas sus Historias, a saber, el léxico relacionado con la educación-enseñanza-aprendizaje. El prosista nos ha legado un vocabulario dotado de profundo rigor lógico y enorme riqueza semántica, con notables puntos de contacto con la medicina coetánea e, incluso, con Eurípides, Le interesó, de modo singular, el léxico referente al poder, al imperio, la conducta humana, las técnicas más recientes. Supo usarlo siempre con acribia, de tal modo que llegó a ser un pionero en captar el significado habitual de las palabras, así como la confusión terminológica propia de momentos de profunda crisis moral y política.

\section{1. $\grave{\alpha} v \alpha \delta 1 \delta \alpha ́ \sigma \kappa \omega(3)^{159}$}

Tucídides nos ofrece en tres ejemplos el verbo correspondiente con el valor de «explicar, hacer saber», sentidos muy próximos al de «enseñar», especialmente cuando,

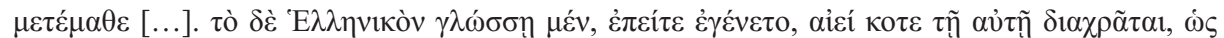

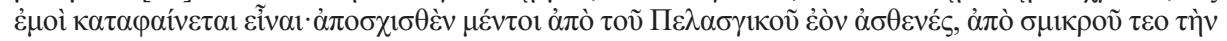

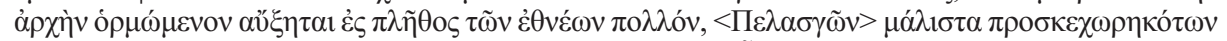

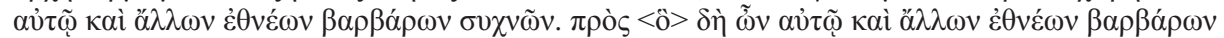

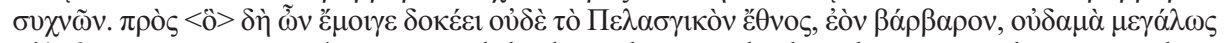
$\alpha \grave{v} \xi \eta \theta \tilde{\eta} v \alpha$. Véase nota 124 a propósito de las dos tradiciones sobre los pelasgos, recogidas por Heródoto. Por su parte, Asheri: 117-118, revisa la «lengua» de los pelasgos, y resume que lo que hoy se acepta por «lengua pelásgica» consiste en unas 5.000 o 6.000 palabras asimiladas al griego, referidas especialmente a plantas, animales e instrumentos, aparte de un número limitado de topónimos terminados en $-s a,-s s o s$, etc.

${ }^{157}$ Tucídides, el ateniense, hijo de Óloro, vivió durante toda la guerra del Peloponeso (431404 a. C.. Cf. 2.65.12; 5.26.1.5; 6.15.3). Nacido hacia el 454, murió después del 399 a. C., pero no pudo terminar su obra (desde la filología alejandrina, llamada Historias de Tucídides). Selecciono algunos estudios sobre el escritor: Drexler, 1976; Dover, 1979; Proctor, 1980; Alsina, 1981; Connor, 1985; Hornblower, 1987; López Férez, 1988: 537-567; Erbse, 1989; Ramón Palerm, 1995, recoge la bibliografía esencial (1973-1995); Tsakmakis-Tamiolaki, 2013; Krieger Balot-Forsdyke-Foster, 2017.

${ }^{158}$ De entre la abundantísima bibliografía sobre la lengua tucididea apunto algunos trabajos donde se muestra su relación con los epinicios pindáricos (Hornblower, 2004), la sofística (Gommel, 1966), la retórica (Friedrichs, 2000; Hagmaier, 2008), la medicina (Weidauer, 1954; Rechenauer, 1991), la poesía (Jung, 1991).

${ }^{159}$ Véase Heródoto, apartado 1. 
como el caso que presentamos, funciona con completivas que recogen lo que se está explicando, $y$, precisamente, en una situación en que quienes hablan quieren mostrar sus razones ante otros, los atenienses. Aunque, en sentido estricto, no estemos en el campo de la educación, ofrezco, por su posible interés, uno de los tres contextos, que ofrecen indudables semejanzas entre sí1 $^{160}$. Efectivamente en el 433 a. C., tanto los corcirenses como los corintios, enemigos declarados entre sí, enviaron sendas delegaciones a Atenas con el fin de atraérsela a su lado para sus planes futuros. Una vez constituida la asamblea, los primeros comenzaron sus razones de este modo: «Justo es, atenienses, que quienes, sin que se les deba un beneficio grande ni una alianza, llegan ante los vecinos a pedir ayuda, como nosotros ahora, se vean necesitados de explicar bien ${ }^{161}$, primero, que, precisamente, piden algo conveniente, y, si no, que no es perjudicial, y, después, que tendrán un agradecimiento constante $[\ldots]{ }^{162}$.

\section{2. $\delta 1 \delta \alpha \sigma \kappa \alpha \lambda \varepsilon i ̃ o v(1)$, «lugar de enseñanza», «escuela».}

El vocablo surge en el siglo $\mathrm{V}$ a. C. Designa el lugar en que se imparte alguna enseñanza. La primera aparición está registrada en el Corpus hippocraticum: «A cuantos casos es preciso actuar con la mano, es necesario acostumbrarse, pues la costumbre es la mejor escuela para las manos ${ }^{163}$. La secuencia pertenece al tratado Sobre los flatos, fechable en el último cuarto del siglo $\mathrm{V}$ y buena muestra del gusto por la retórica entre algunos escritores médicos. El sustantivo estudiado lo leemos también en Antifonte ${ }^{164}$, pero referido allí a una escuela de coros. Nuestro historiador, pues, figura entre los primeros que usan el nombre que nos interesa. El texto tucidideo nos presenta uno de los episodios más crueles y sanguinarios de la guerra del Peloponeso. Se trata de unos hechos ocurridos en el año $413 \mathrm{a}$. C. Los peltastas tracios (mil trescientos, en número), armados con sables, habían acudido a Atenas para marchar a Sicilia en la expedición de refuerzo comandada por Demóstenes ${ }^{165}$. Pero, por haber llegado tarde,

${ }^{160}$ Cf. 3.97.1, los mesenios aconsejan a Demóstenes; 8.86.1: los enviados por los Cuatrocientos han de darles explicaciones a los samios.

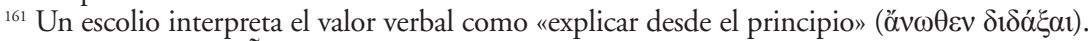

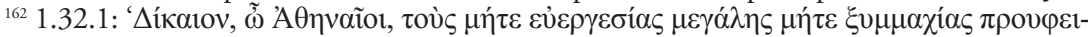

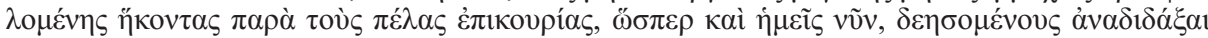

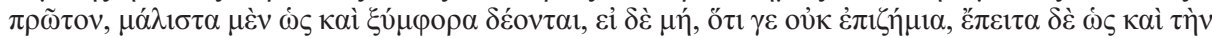

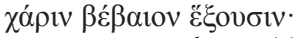

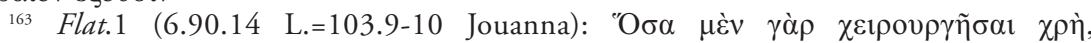

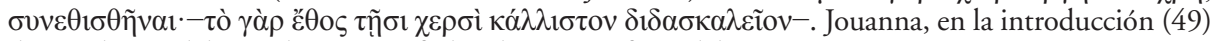
de su edición del tratado (1988), fecha el escrito a fines del v.

${ }^{164}$ 6.11. Sobre el autor, véase nota 268.

${ }^{165}$ Famoso general ateniense de amplia trayectoria y notables éxitos durante la Guerra del Peloponeso fue enviado a Sicilia en el 413 para reforzar las tropas mandadas por Nicias. Tras fracasar en un intento de apoderarse de las Epípolas, colina próxima a Siracusa, ordenó la retirada del ejército, pero Nicias, general en jefe, no la aceptó. Finalmente, huyendo los atenienses por tierra, hostigados por los siracusanos, Demóstenes se rindió, y, poco después, lo hizo Nicias. Ambos fueron ejecutados. El número de prisioneros atenienses fue, al menos, de 7.000. En 7.87 el escritor resume la derrota, que suele situarse en septiembre del 413. 
los atenienses los enviaron de nuevo a Tracia, encargándole a Dí́trefes, responsable y jefe de todos, que, durante su marcha hasta su destino, les ordenara hacer algún daño a los enemigos, si podía ${ }^{166}$. Pues, bien, los tracios, en su camino de regreso por el Euripo, desembarcaron, sometieron a pillaje a Tanagra, atravesaron el estrecho y atacaron de improviso Micaleso ${ }^{167}$, pequeña localidad de Beocia. Tucídides, tan parco por lo general en adjetivar los hechos, no ahorra aquí calificativos, pues, sin duda, quedó profundamente impresionado por lo sucedido. Los tracios, en efecto, mataron a las personas «sin respetar ni a las edades avanzadas ni a las bastante jóvenes, sino a todos, a unos después de otros, dando muerte incluso a los niños y mujeres, y, además, a las bestias de carga y a cualquier otro animal que veían ${ }^{168}$. A continuación, el prosista añade los detalles que más nos interesan:

La estirpe de los tracios, en efecto, de modo semejante a los más de entre los bárbaros, cuando se siente segura, es muy sanguinaria. También entonces había acontecido otra perturbación no pequeña y toda clase de $\operatorname{crimen}^{169}$, y, habiendo atacado de improviso una escuela de niños que era allí muy grande -casualmente, los niños habían acabado de entrar- los aniquilaron ${ }^{170}$ a todos. Sobrevino a la ciudad entera una desgracia no inferior a ninguna; más que cualquier otra, inesperada, y esa misma también terrible ${ }^{171}$.

El contexto requiere cierta demora. Nos interesa subrayar una serie de indicadores léxicos y sintácticos, como muestra del interés del historiador por describir en pocas palabras un hecho de gran importancia social: el adjetivo $\mu \varepsilon ́ \gamma ı \sigma \tau o v$, «muy

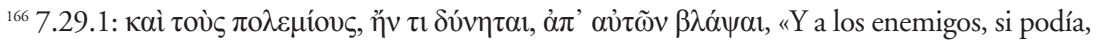
que les hiciera daño valiéndose de ellos (sc. los tracios)». Esta breve indicación nos aclara que los terribles hechos que van a venir después sucedieron por órdenes directas de los atenienses, posiblemente con el fin de sembrar el terror entre los enemigos. Dí́trefes parece ser el mismo mencionado en 8.64.1: el jefe militar del territorio de Tracia.

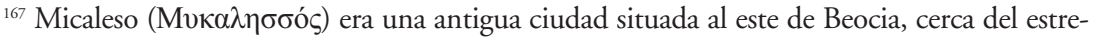
cho del Euripo y de la ciudad de Calcis, precisamente en el lugar que hoy ocupa la actual Ritsona.

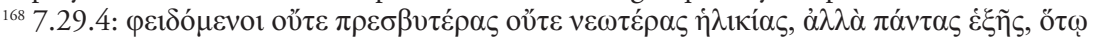

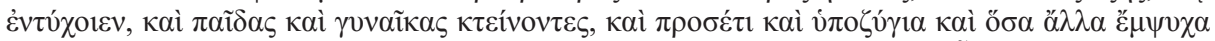

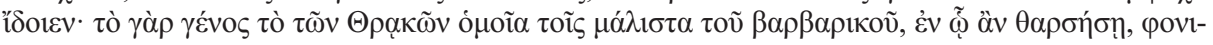

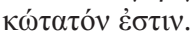

${ }^{169}$ Son los hechos relatados por el historiador en 7.29.4-5, a saber: saquearon las casas y los templos y, a continuación, mataron a todo el mundo.

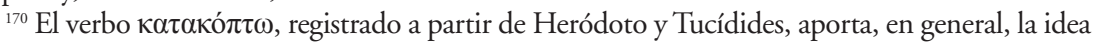
de «cortar en trozos», «despedazar».

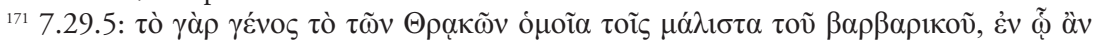

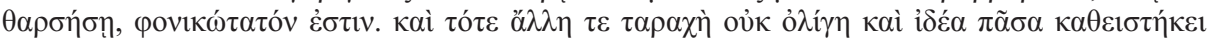

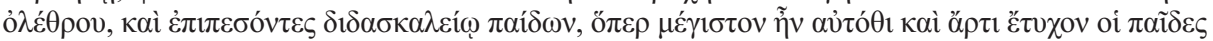

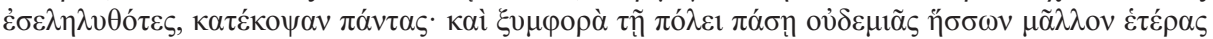

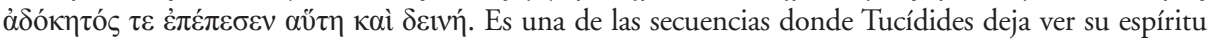
humanitario: cf. Orwin, 1994: 133-135. 
grande», en grado superlativo absoluto, atribuido al edificio de la escuela ${ }^{172}$; asimismo, la precisión aportada por el genitivo epexegético «de niños», pues, dicho de ese modo, se deja abierta la posibilidad de la existencia en aquellos momentos -allí mismo o en otras partes- de otra escuela, apropiada para, o especializada en, quienes no eran

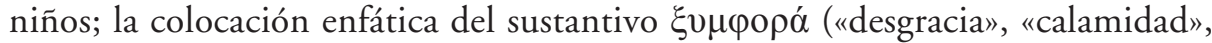
entiéndase sobrevenida a Atenas, donde todo el mundo se quedaría trastornado al enterarse de lo acaecido), en primer plano, para llamar la atención, seguido de tres precisiones importantísimas: la primera, marcadora y evaluadora de la gravísima crueldad

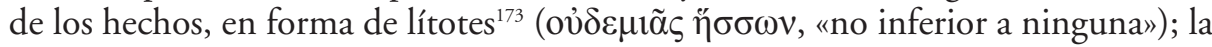

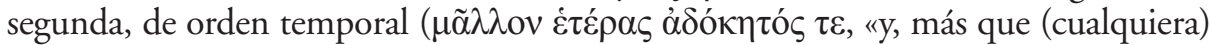
otra, inesperada»), donde el factor sorpresa (eran los primeros momentos del día y las puertas de la ciudad estaban abiertas, porque no temían nada parecido pues la localidad estaba a considerable distancia del mar) es el elemento clave, pues nadie pudo escapar por haber ocurrido todo de modo repentino e insospechado; la tercera, y última, en lugar enfático, delimitador y corona de la frase, es el calificativo de

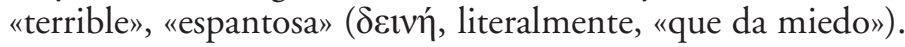

\section{3. $\delta 1 \delta \alpha \sigma \kappa \alpha \lambda i ́ \alpha(3)^{174}$, «enseñanza».}

El sustantivo aparece en el siglo $\mathrm{V}$ a. C. Píndaro ${ }^{175}$ es el primero en usarlo. Lo registran también, entre otros, el Corpus Hippocraticum ${ }^{176}$ y Jenofonte (7). El término fue ampliando su contenido semántico. Los diccionarios al uso distinguen varios valores. Resumiéndolos tendríamos: 1. «enseñanza, instrucción»; 2. «instrucción»,

${ }^{172}$ A la vista de las palabras del prosista, Hornblower: III, 599, se pregunta por cuántas escuelas habría allí.

${ }^{173}$ Sobre la figura estilística en el escritor, véase Pontier: 353-370.

${ }^{174}$ Los femeninos griegos en $-i \bar{a}$ (con $\bar{a}$ larga) están dotados de un sufijo muy antiguo, bien establecido desde los primeros textos literarios, el cual crea sustantivos a partir de otros sustantivos

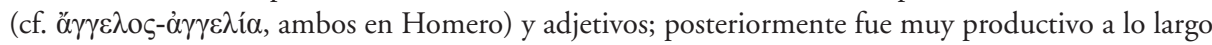
de toda la historia de la lengua griega. Cf. Schwyzer: I, 468-469.

${ }^{175}$ Cf. P. 4.102.

${ }^{176}$ En dos ocasiones, en Ley (Lex), un escrito de finales del v o comienzos del IV: cf. Craik: 155. Veamos los pasajes (Lex 2. 4.638.13-640.1 L.): «Pues es preciso que, quien haya de ajustarse perfectamente al conocimiento de la medicina, esté provisto de lo siguiente: naturaleza, enseñanza, lugar opor-

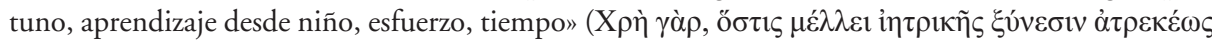

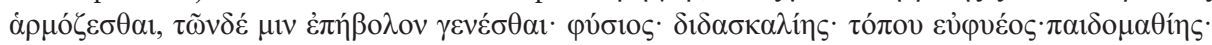
$\varphi \imath \lambda o \pi$ ovín $\cdot \chi \rho o ́ v o v)$. Unas líneas después leemos: «Pero cuando la naturaleza se encamina hacia lo mejor,

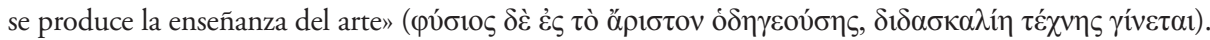
En ambos contextos el sustantivo revisado debe interpretarse, a mi entender, en sentido pasivo, es decir, la enseñanza que ha de recibir quien desea conocer la medicina. 
«norma»; 3. «representación» de una obra dramática; 4. «obra dramática»; 5. «indicación o catálogo de las obras de teatro».

En Tucídides encontramos el sustantivo mencionado con el valor de "explicación», «consejo». Así sucede en dos ocasiones: «habría necesidad de explicación para quienes no lo saben»" ${ }^{177}$; asimismo en la expresión "dando (literalmente, "haciendo») la explicación ${ }^{178}$, según el giro analítico tan grato al prosista. El tercer ejemplo, en cambio, está muy cerca del campo léxico de la educación, precisamente el que nos interesa, y, por ese motivo, he creído oportuno recogerlo. Tras la batalla naval de Río (429 a. C.), hablan los jefes peloponesios dando ánimo a sus hombres, diciéndoles entre otras cosas lo siguiente: «Y, en las más de las ocasiones, el poder es de los más numerosos y mejor preparados, de manera que no encontramos ni siquiera aspecto alguno por el que nosotros, de modo verosímil, pudiéramos sufrir la derrota. E, incluso, cuantos errores cometimos antes, ésos mismos, añadiéndose ahora, proporcionarán una enseñanza ${ }^{179}$. Estamos ante una idea digna de señalar, pues es paralela, en cierto modo, a la afirmación casi religiosa según la cual del sufrimiento viene el aprendizaje ${ }^{180}$. Los errores cometidos, personificados aquí, son los portadores de enseñanza. El pasaje es ilustrador y puede resumirse de modo telegráfico: la inexperiencia ha perjudicado a los peloponesios, pues era la primera vez que reñían combate naval; son inferiores en experiencia, pero superiores en valor. Por otra parte, el miedo anula la memoria, y la técnica sin valor de nada sirve.

4. $\delta 1 \delta \alpha ́ \sigma \kappa \alpha \lambda o \varsigma$ (4), «el que enseña», «maestro».

Este sustantivo surge en el siglo VII (Alcmán: 2), lo leemos en el VI (Himno homérico A Hermes, Heráclito) e incrementa notoriamente sus usos en el v: en los tres trágicos, Esquilo (7) ${ }^{181}$, Sófocles (3) y Eurípides (7); también en filósofos como Demócrito, e, incluso en la literatura científica, con una muestra en el Corpus Hippocraticum. En Tucídides, lo vemos, por un lado, con el sentido de «los expertos» ${ }^{182}$, los especialistas en propalar un rumor mencionado algo antes, contexto en que se alude a los corintios, y, por otro, como «el que aconseja o inspira una decisión»" ${ }^{183}$, donde

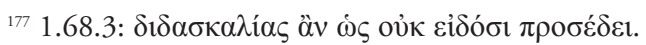

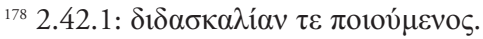

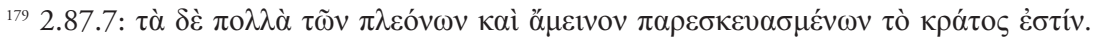

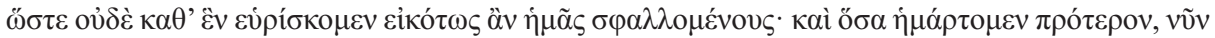
$\alpha$ $\tau \dot{\tau} \tau \alpha \tilde{\tau} \tau \alpha \pi \rho \sigma \gamma \varepsilon v o ́ \mu \varepsilon v \alpha \delta 1 \delta \alpha \sigma \kappa \alpha \lambda i ́ \alpha v \pi \alpha \rho \varepsilon ́ \xi \varepsilon 1$.

${ }^{180} \mathrm{Cf}$. nota 116.

${ }^{181}$ Siete apariciones; cuatro de ellas en Prometeo (110, 322, 373, 391).

182 5.30.1.

183 8.45.1. 
se trata de Alcibiades ${ }^{184}$, el cual se había refugiado junto a Tisafernes ${ }^{185}$. Como veremos en el caso del verbo correspondiente ( $\delta \delta \delta \alpha ́ \sigma \kappa \omega)$, es llamativo, y, a mi entender, no ha sido suficientemente destacado, el hecho de que se pongan en relación con el citado político ateniense formas de la familia léxica que estamos viendo. Alcibiades fue, a la larga, funesto para la política ateniense: intrigante, traidor, populista y demagogo. Podría verse, pensamos, una idea negativa sobre los resultados a que conducen ciertas malas «enseñanzas» cuando individuos tan desleales y nefastos las proporcionan.

En los otros dos pasajes, nos acercamos más al campo de la educación tal como a nosotros nos interesa.

4.1. Primero, dentro de una secuencia donde, en el 427 a. C., ante la Asamblea ateniense, habla Diódoto ${ }^{186}$, el cual esgrime argumentos contra la ejecución de los mitilenios: «Quien propugna que las palabras no son maestras de las acciones, o es torpe o tiene algún interés en privado ${ }^{187}$. Obsérvese: son las palabras las que indican, explican, sirven de guía, avanzan lo que va a suceder. Notemos, pues, la perso-

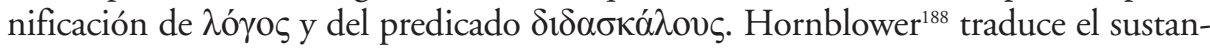
tivo que estudiamos por "guías en la acción», e insiste en que siempre está utilizado en sentido metafórico dentro de la historia tucididea. Por su lado, desde Esquilo ${ }^{189}$ conocemos la construcción del sustantivo que revisamos con un genitivo explicativo.

${ }^{184}$ Político ateniense, muy destacado en buena parte de la guerra del Peloponeso, como orador y general. Impulsó la expedición a Sicilia, se refugió en Esparta cuando fue acusado de sacrilegio y aconsejó a los espartanos cómo destruir Atenas y su imperio; posteriormente fue consejero de Tisafernes, buscando siempre la ruina de su patria. La traición fue quizá la nota más destacada de su actuación como político. Más noticias en las notas 199, 200, 201. Para la presencia del político en las Historias tucidideas, véanse, entre otros, Delebecque, 1965 y Forde, 1989.

${ }^{185}$ Sátrapa persa con plenos poderes sobre Lidia y Licia. Muy mencionado en la historia tucididea (sólo en el libro octavo: 5.4.5, 6.1.2.3, 16.3, 17.4, 18.1, etc.), Jenofonte también lo cita con frecuencia ( $H G 1.1 .9 .31,2.6 .8,5.2 .8$, etc.).

${ }^{186}$ Aludido dos veces por el historiador $(3.41 ; 49.1)$. Con sus razonamientos, se alinea en la línea moderada, democrática, continuadora de la política de Pericles. Durante la Asamblea celebrada en el verano del 427 se opuso de modo frontal a las proposiciones de Cleón, partidario de aniquilar a los mitilenios varones mayores de edad y vender como esclavos a mujeres y niños por haber hecho defección del imperio ateniense.

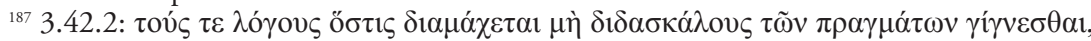

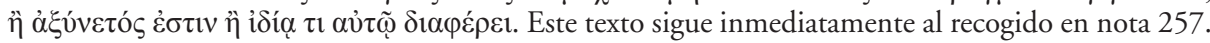

${ }^{188}$ Hornblower: I, 432.

${ }^{189}$ Eum. 584: (Habla Atenea) «El que acusa, hablando el primero desde el comienzo/ sería, con

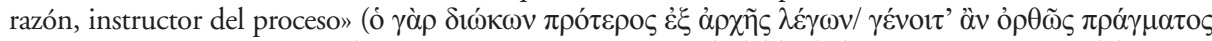
$\delta 1 \delta \alpha ́ \sigma \kappa \alpha \lambda \mathrm{\varsigma})$. Por su parte, Platón aporta un testimonio indudable de la riqueza semántica del sustantivo revisado, precisamente mediante la delimitación con genitivo explicativo o epexegético, construcción que le sirve para crear categorías especiales de «maestros». (No se descarta explicar estos genitivos como de cualidad, en cuanto expresan la pertenencia a una clase o categoría). Dependiendo, pues, de «maestro» tenemos en el filósofo una larga lista de sustantivos o asimilados en genitivo: virtud, justicia, persuasión, educación, música, retórica, hablar griego, caballos, arcos, dardos y hondas. Para más información, López Férez, 1997b y 2000b: 78. 
4.2. Más claro resulta el siguiente ejemplo, donde el autor está comentando las consecuencias de la guerra civil acaecida en Corcira (427 a. C.): «La guerra, al suprimir la facilidad de cada día, es un maestro violento y adapta a las circunstancias las emociones de la mayoría ${ }^{190}$. Tenemos aquí dos ideas muy importantes: por un lado, la guerra, o sea, una acción de efectos terribles, es maestra, transmite alguna enseñanza; otra personificación, en este caso «la guerra», como también sucede en otro lugar ${ }^{191}$. Por otro, se nos advierte que es un maestro violento (ßíalos), es decir, que se presenta de modo vehemente, y en modo alguno resulta ser alguien apreciado ni deseado; no utiliza la persuasión -elemento esencial en quien quiere enseñar algo-, sino la fuerza bruta. En la expresión ßíatos $\delta 1 \delta \alpha ́ \sigma \kappa \alpha \lambda$ os se ha visto un oxímoron, libertad estilística tan dilecta del historiador ${ }^{192}$. De una parte tenemos juntos conceptos que debieran ser antagónicos ${ }^{193}$; de otra, el lector preparado relacionaría con bastante facilidad la enseñanza y la persuasión, pensando que todo maestro que se precie ha de ser moderado con sus discípulos, especialmente en una época en que casi todos los maestros de Atenas eran privados, es decir, pagados por los padres de los alumnos ${ }^{194}$. Gomme ${ }^{195}$ afirma que la mencionada sentencia le parece una de las convicciones más fuertes y profundas de Tucídides, expresada, además, con notable claridad. El estudioso inglés señala que, en este pasaje, el eximio historiógrafo -que con frecuencia pone en boca de otros la teoría del dominio del fuerte sobre el débil- parece apartarse de la doctrina de la fuerza bruta, de la preponderancia y mando del más fuerte. Añadamos que, posiblemente, es Platón, de modo conspicuo en el Gorgias ${ }^{196}$ y por boca de Calicles, quien mejor recoge estas ideas propugnadas en ciertos círculos sofistas. También en algunos fragmentos de los cínicos pueden hallarse reflejos de esos pensamientos. Hay que tener en cuenta que un poco antes

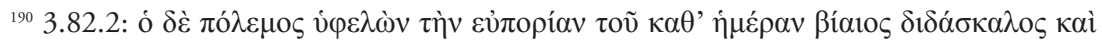

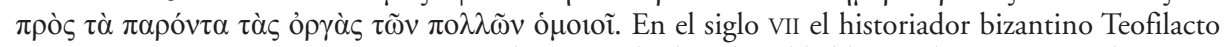
Simocata (Historias 1.15.6) nos presenta al persa Mebodes, el cual habla ante los enemigos: «la guerra, lo afirmo yo, es arquetipo y directora de los males humanos, maestro que aprende solo" (ó $\pi$ ó $\lambda \varepsilon \mu o \zeta$,

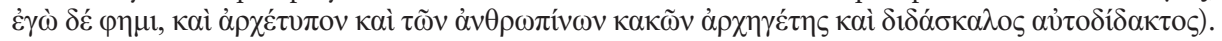
Por su lado, ya en XIII, el emperador e historiógrafo Juan Cantacuceno, Historias, 2.178, conoce bien y parafrasea la sentencia del ateniense..

1911.122 .1 .

${ }_{192}$ Macleod, 1979: 124. Sobre la expresión, Rechenauer-Potho, 2011.

${ }^{193}$ De ahí el oxímoron, vocablo que, en sentido etimológico, equivaldría a «algo que saca (o a lo que se le saca) punta (o sentido) de modo loco». Para la etimología, véase Chantraine, 1968: 731.

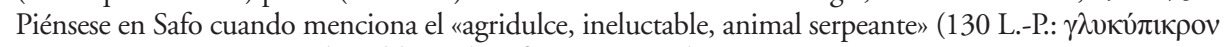
$\dot{\alpha} \mu \alpha \dot{\alpha} \alpha$ vov ő $\rho \pi \varepsilon \tau o v)$, modo sublime de referirse a eros, la pasión amorosa.

${ }^{194}$ Con todo, sabemos que no faltaban en la época maestros duros e inflexibles: Cf. Jenofonte, $A n$. 2.6.12, donde se alude a Clearco (general espartano al servicio de Ciro el Joven) como carente de atractivo, duro y cruel, de tal modo que sus soldados se comportaban con él como los alumnos con el maestro.

${ }^{195}$ Gomme: II, 373.

${ }^{196}$ Cf. Grg. 483d.e; 489c. 
de la secuencia que estamos revisando, nuestro historiógrafo, tan parco, por lo general, en calificar a las personas, ha llamado a Cleón, «el más violento de entre los ciudadanos ${ }^{\prime 197}$. El lector entendido y culto para quien están escritas las Historias hallaría ahora una indudable resonancia del adjetivo citado anteriormente, y, sobre todo, lo relacionaría con un tipo de política basado en la demagogia, tal como se desprende de las sucesivas intervenciones de Cleón en la obra del historiógrafo ateniense ${ }^{198}$.

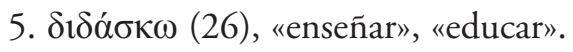

En Tucídides este verbo es bastante utilizado si lo comparamos con Heródoto (26 usos, frente a 17) y tiene, en general, el valor de «mostrar», «explicar», «advertir», «aconsejar». En cuatro ocasiones se refiere a Alcibiades (6.93.1 ${ }^{199} ; 7.18 .1^{200} ; 8.45 .3$; $56.2^{201}$ ): creo que, en esos contextos, dicho vocablo está cargado de connotaciones negativas. El ejemplo más claro, según nuestra opinión, es aquel en que se nos refieren los consejos que Alcibiades le daba a Tisafernes. Aquél se había pasado al bando enemigo y trataba de hacerle todo el daño posible a Atenas: «Y además le enseñaba hasta el punto de que, dándoles dinero, convenciera a los trierarcos y estrategos de las ciudades, de modo que estuvieran de acuerdo en eso con él, con excepción de los siracusanos ${ }^{202}$. Debe subrayarse cómo Alcibiades aconsejaba ganarse la voluntad de los cargos militares y políticos, a saber, sobornándolos con riquezas. Es decir, estamos ante una "enseñanza», sí, pero perversa: corromper mediante dádivas. Es

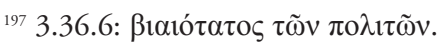

${ }^{198}$ Rawlings (III), 1981, se ocupa de las resonancias de pasajes de las Historias en otras secuencias de la misma obra.

${ }^{199}$ Los lacedemonios reciben una explicación ofrecida por Alcibíades, en la idea de que era quien mejor conocía la situación; tras eso se decidieron a fortificar Decelia.

${ }^{200}$ Alcibiades aconseja insistentemente a los lacedemonios que fortifiquen Decelia.

${ }^{201}$ Tisafernes es aleccionado por Alcibiades para desgastar a los dos bandos: peloponesios $\mathrm{y}$ atenienses.

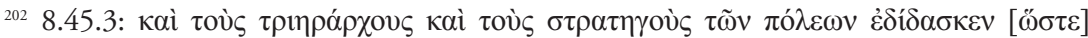

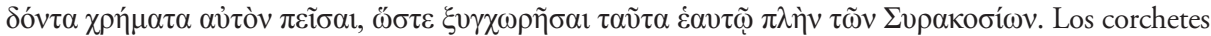
verticales corresponden a una seclusión de J. Reiske (Animadversiones ad Graecos Auctores. Quo Thucydides, Herodotus et Aristides pertractantur III, Leipzig, 1761). Classen-Steup: VIII, 105, aceptan la propuesta de Reiske, pero dan una buena explicación: el $̋ \sigma \tau \varepsilon$ que sigue a $\varepsilon \delta \delta i \delta \alpha \sigma \kappa \varepsilon v$ consta en todos los manuscritos, mientras que el segundo falta en el manuscrito B (Vaticanus 126). Por otro lado, si la conjunción $\omega ̋ \sigma \tau \varepsilon$ es corriente con $\pi \varepsilon i ٓ \sigma \alpha 1$, en cambio, es rara con $\delta 1 \delta \alpha ́ \sigma \kappa \omega$. Además, señalan que, en el imperfecto del verbo que examinamos, cabe ver la insistencia en el tiempo que Alcibiades gastaría en conseguir sus propósitos. Con todo, en el plano sintáctico no hay problema para conservar ambos ஸ̋ $\tau \varepsilon$, aparte de la posible cacofonía causada por la repetición. Por lo demás, la corrupción del poder mediante sobornos en los años finales de la guerra del Peloponeso, especialmente durante la campaña de Sicilia, ha sido estudiado por Kallet, 2001. Por su lado, Price, 2001, analiza los problemas añadidos, especialmente en Atenas, a causa de la guerra interna entre facciones opuestas, durante el conflicto bélico.
} 
importante subrayar el valor negativo de $\delta$ ió $\sigma \kappa \omega$ en contextos semejantes mediante el análisis de las razones apuntadas por el escritor. Es una buena manera, creo, para justificar la correspondiente connotación peyorativa.

Con las debidas reservas le presento al lector siete ejemplos donde nos vamos acercando paulatinamente al valor pleno de «enseñar» algo a otro, en el sentido que estamos buscando dentro de este trabajo. Además, otros dos textos en que entramos ya en el terreno de la educación.

5.1. En cuatro ocasiones encontramos la voz activa. En el primer caso, durante la primavera del 415 a. C., Nicias ${ }^{203}$, general ateniense, elegido contra su voluntad jefe de la expedición militar a punto de partir para Silicia, habla ante la Asamblea, intentando disuadir, ante todo, a los partidarios de emprender aquélla. Sabe, y lo manifiesta, que les está hablando a quienes, tras una breve votación, están dispuestos a acometer una guerra de resultados imprevisibles; les recomienda conservar lo que tienen y no arriesgar sus posesiones en tierras lejanas a propósito de asuntos dudosos y futuros: «Y que ni os afanáis en momento oportuno ni es fácil conseguir lo que pretendéis, eso os lo enseñaré» ${ }^{204}$. El orador quiere dar una lección, a saber, apoyándose en diversos argumentos, hacerles ver a sus conciudadanos que estaban equivocados en sus propósitos. Pienso que estamos muy cerca del terreno de la educación, pues hay un responsable de impartir la lección, un mensaje que se quiere transmitir y unos oyentes que han de recibirlo.

5.2. Una vez llegadas a Sicilia noticias de la citada expedición ateniense, Atenágoras, máximo representante del partido popular, intenta convencer al pueblo de Siracusa de cómo había que actuar frente a los partidarios de la oligarquía: de una parte persuadiendo a la mayoría; y, de otra «con respecto a los oligarcas, acusándoles de unas cosas, guardándonos de ellos en otras y enseñándoles otras. Pues me parece que así los disuadiremos muchísimo de su maldad $»^{205}$. La sintaxis del párrafo no es

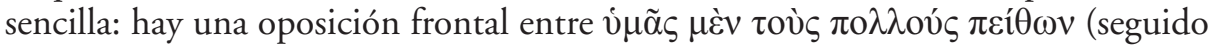

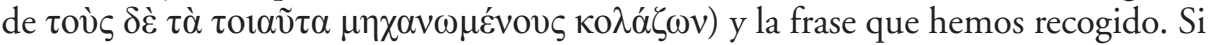
nos fijamos bien, $\mu \varepsilon^{\prime} v$ va seguido de un $\delta \varepsilon$, más una serie de paréntesis, más otro $\delta \dot{\varepsilon}$,

${ }^{203}$ Político y general ateniense, miembro de la clase privilegiada de Atenas y propietario de una enorme fortuna, rival de Cleón en diversas ocasiones, contrario a la política imperialista de su patria, partidario de hacer la paz con Esparta y acabar de una vez la terrible guerra del Peloponeso, fue el principal responsable de la Paz que lleva su nombre (421 a. C.). Nombrado estratego en varias ocasiones, fue el general en jefe de la expedición a Sicilia, donde, una serie de errores propios y de éxitos de los siracusanos bajo el mando de Gilipo, general espartano, llevó a la derrota de Atenas por tierra y mar. Tras haberse rendido, sus enemigos le dieron muerte en el 413 a. C. Cf. nota 165.

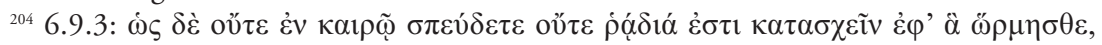
$\tau \alpha \tilde{\tau} \tau \alpha \delta 1 \delta \alpha \xi \omega$. Hornblower: III, 326, afirma que «enseñaré» subraya la idea del orador como maestro.

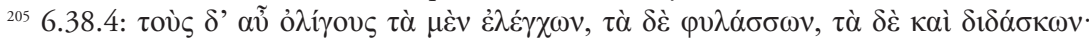

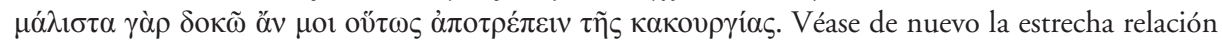
entre la acción de «enseñar» y el orador que está pronunciando el discurso. 
en el que me voy a detener. De los tres participios presentes en el pasaje ofrecido, los dos primeros, $\dot{\varepsilon} \lambda \dot{\varepsilon} \gamma \chi \omega \vee$ y $\varphi v \lambda \alpha ́ \sigma \sigma \omega v$, cabe entenderlos referidos al pueblo, al partido popular, que ha de encargarse de esas dos actividades («acusándoles» y "guardándonos»), pero el tercero, $\delta 1 \delta \alpha ́ \sigma \kappa \omega v$, según varios comentaristas ${ }^{206}$, está reservado a lo que debe hacer el orador, quien tiene por misión aquí enseñarles a los poderosos ciertos detalles.

5.3. Si en los dos textos anteriores el verbo examinado lleva un objeto directo referente a la materia enseñada, en el expuesto a continuación el objeto directo resulta ser precisamente quienes reciben la enseñanza, o lección. Efectivamente, los atenienses, tras organizar una expedición contra la isla de Melos y acampar allí en el verano del 416 a.C., enviaron unos legados para tratar con los habitantes, pero los melios no los introdujeron en la asamblea, sino que les hicieron hablar ante unos pocos hombres de elevado rango. Entonces, los atenienses les sugirieron que no respondieran con un solo discurso, sino que contestaran punto por punto a los términos que no les parecieran bien conforme se los fueran proponiendo. A esto, los consejeros de los melios contestaron así: «No se censura la benignidad de darnos mutuamente lecciones con tranquilidad, pero lo de la guerra, estando ya presente y no demorándose, se muestra en desacuerdo con eso mismo ${ }^{207}$. Dionisio de Halicarnaso ${ }^{208}$ ya reparó en las dificultades de la secuencia, subrayando las faltas de concordancia en número y caso, pues tras un femenino singular $(\dot{\varepsilon} \pi 1 \varepsilon i ́ \kappa \varepsilon 1 \alpha)$ y un neutro plural ( $\tau \dot{\alpha}$ $\delta \grave{\varepsilon} \tau o \tilde{~} \pi \mathrm{o} \lambda \dot{\varepsilon} \mu \mathrm{ov})$ llegamos a un genitivo recapitulador de lo expresado ( $\alpha \hat{\tau} \tau o \tilde{v})$, el cual plantea dificultades, por lo que el retórico sugiere que habría que poner $\alpha \grave{\tau} \tilde{\eta} \varsigma$

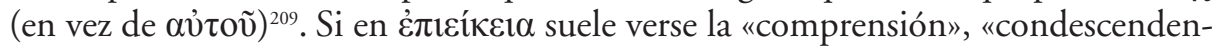
cia» o «indulgencia» de un superior respecto a un inferior, situación en que estarían

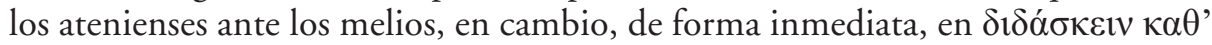

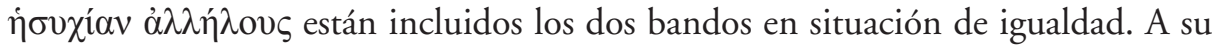

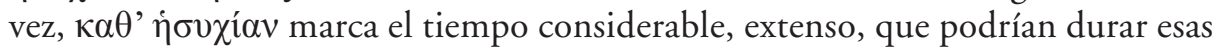
«lecciones» mutuas.

${ }^{206}$ Cf. Classen-Steup: VI, 91.

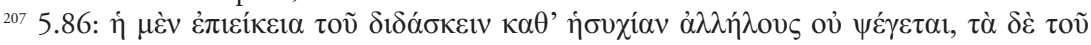

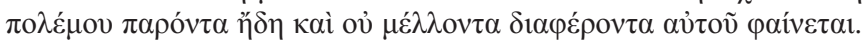

${ }^{208}$ Dionisio de Halicarnaso, Th. 37, se detiene en el pasaje y ofrece el texto tucidideo con

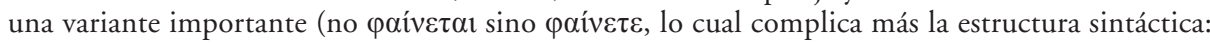
«mostráis», referido a los atenienses, cuyo objeto directo serían las circunstancias de la guerra, etc.). Ahora bien, en el texto final propuesto por Dionisio, sí tenemos la lectura recogida en todas las ediciones

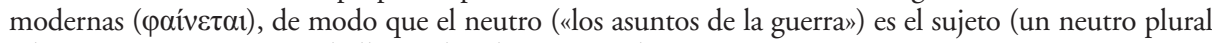
sabemos que, en ático, suele llevar el verbo en singular).

${ }^{209}$ El rétor de Halicarnaso, ibid., se detiene en av่นoṽ e indica que alguien podría llamarlo

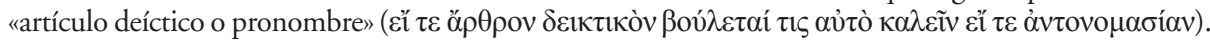
Algunos comentaristas han querido ver en el genitivo una referencia sólo a $\delta 1 \delta \alpha ́ \sigma \kappa \varepsilon ı v$ (cf. ClassenSteup: V, 208). 
5.4. Veremos ahora el verbo que nos compete con objeto directo de persona a quien se transmite algún conocimiento y un giro en genitivo con la preposición $\pi \varepsilon \rho i ́$, con que se apunta a la materia de la cual se está enseñando algo ${ }^{210}$. El pasaje nos presenta a los generales atenienses cuando buscaban para desembarcar un lugar idóneo de la costa siciliana, en el cual la caballería siracusana les molestara lo menos posible: «Y les daban una lección sobre el lugar próximo al Olimpieo, precisamente el que tomaron, los desterrados de los siracusanos que les seguían $»^{211}$. Aquí hay algo más que la simple noticia, advertencia o información, pues se está facilitando un conocimiento esencial para situarse estratégicamente frente a los enemigos. Estamos rozando, al menos, el campo de la enseñanza.

5.5. Un pasaje nos ofrece la voz media. En el contexto siguiente, fijémonos cómo de «explicado perfectamente» algo por obra de alguien, se pasa a la noción de "haber recibido una enseñanza», "haber aprendido perfectamente», gracias a las palabras de alguien. Efectivamente, en el invierno de 412-411, Pisandro ${ }^{212}$ les recomendó a los atenienses que, o redujeran el número de ciudadanos encargados de los asuntos de la ciudad, o hicieran venir a Alcibiades, el cual, a la sazón, se dedicaba a adular a Tisafernes: «El pueblo, al principio, oyéndolo, soportaba con dificultad lo referente a la oligarquía, pero recibiendo por obra de Pisandro la lección de que no había otra salvación, temiendo y al mismo tiempo confiando en que lo cambiaría, cedióo ${ }^{213}$. Repárese en el genitivo agente, indicador de la persona que realiza la acción.

5.6. Tanto el texto que ahora exponemos como el siguiente nos acercan mucho al terreno de la educación. Cuando Temístocles (466 a. C.), perseguido por quienes

${ }^{210}$ El propio historiador presenta otro ejemplo de tal construcción en 3.71.2; luego, será frecuente entre los oradores, destacando, con mucho, Isócrates $(14.7 ; 15.58 ; 16.2 ; 17.51 ; 18.44 ;$ Ep. 9.19); también lo recoge Aristóteles: he aquí un caso paralelo tomado del estagirita (Protr. 467): «Pues unos son sólo artesanos de la virtud del cuerpo, otros, siéndolo sobre las virtudes del alma y pretendiendo enseñar también sobre la felicidad y desgracia de la ciudad, necesitan mucho más de la filosofía»

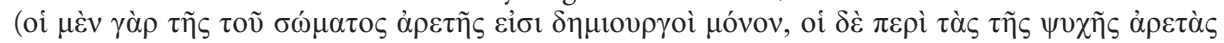

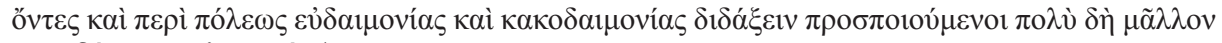

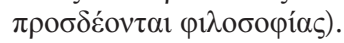

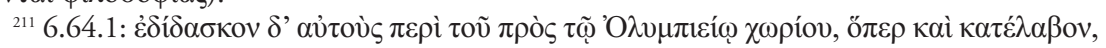

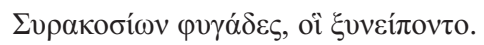

${ }^{212}$ Tras la conjuración de Samos (invierno de 412-411 a. C.) para derrocar la democracia ateniense (6.48-49), los atenienses reunidos en dicha isla nombraron representante a Pisandro, un conciudadano. Éste, una vez perdida su influencia y destituido de su cargo (6.54), exhortó a las sociedades secretas atenienses a derribar la democracia; obró con la misma intención en Samos (6.63.3) y navegó a Atenas con el mismo propósito (6.65.1); fue el que más contribuyó a la ruina de la democracia en su ciudad (6.68.1); destacó entre los Cuatrocientos (6.90.1), y, una vez depuestos los mismos y entregado el poder a los Cinco mil, se refugió en Decelia (8.98.1) junto con los principales oligarcas.

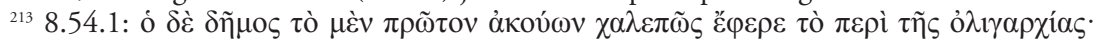

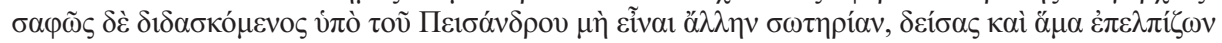
$\omega \varsigma \zeta \kappa \alpha i \grave{\mu \varepsilon \tau \alpha \beta \alpha \lambda \varepsilon i \tau \tau \alpha 1, ~ \varepsilon ̇ v \varepsilon ́ \delta \omega \kappa \varepsilon v . ~ D e ~ l a ~ a c t i t u d ~ d e ~ P i s a n d r o ~ e n ~ e s t e ~ l i b r o ~ s e ~ o c u p a ~ H e i t s c h, ~ 2007, ~ e s p e-~}$ cialmente en 88-90. 
habían recibido la orden de hacerlo, se refugió en casa de Admeto, rey de los molosos y enemigo suyo a la sazón, el historiador destaca lo extraño de la situación: «pero uno (sc. Admeto) no se encontraba en la ciudad, y el otro (sc. Temístocles), convirtiéndose en suplicante de su esposa, recibe instrucciones por obra de ella: tomar el niño de ambos en brazos ${ }^{214}$ y sentarse junto al hogar $\aleph^{215}$. Observemos que hay una persona (la esposa del monarca) que da unas recomendaciones o instrucciones, las cuales vienen construidas en infinitivo completivo. La voz media del verbo que nos interesa no cambia mucho el valor del mismo: si la voz activa es enseñar, la media es recibir una enseñanza o recomendación de parte de alguien.

5.7. Leamos ahora una secuencia importante para entender los enfrentamientos agonales, dialécticos, donde dos antagonistas intentar convencer al otro recurriendo a argumentos de toda índole. La tenemos en el diálogo-agón entre los melios y los atenienses. Hablan los primeros: «¿Y consideráis que no hay seguridad en lo siguiente? Pues es preciso también ahora que, tal como vosotros, partiendo de argumentos justos, intentáis convencernos para que obedezcamos a vuestro interés, también nosotros, enseñándoos lo que es útil para nosotros, si lo mismo también resulta conveniente para vosotros, intentemos convenceros $»^{216}$. En el agón, los pasos dialécticos son los siguientes: primero enseñar (explicar, mostrar al otro) lo que es útil; después, convencerlo ${ }^{217}$.

5.8. Siguen ahora dos secuencias en que, en mi opinión, estamos en el campo de la educación. La primera, de la que me ocupará a continuación, es quizá la más interesante. Después que en el verano del 425 a. C. los atenienses se apoderaran de Pilos y consiguieran bloquear por mar la isla Esfacteria donde había 420 peloponesios más los hilotas que les servían, los pelopenesios abrieron las negociaciones para lograr una tregua. Sus embajadores hablan en Atenas:

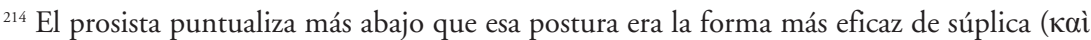

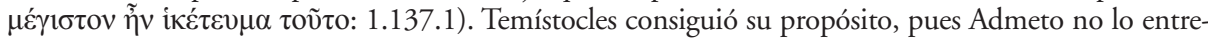
gó a los lacedemonios que llegaron para reclamarlo, y, después le procuró una escolta y lo envió a Pidna, desde donde tomó un barco para escapar a Jonia.

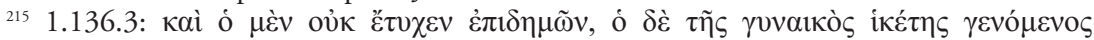

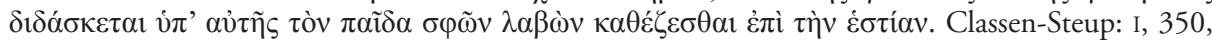
interpretan $\delta 1 \delta \alpha ́ \sigma \kappa \varepsilon \tau \alpha \iota$ en el sentido que le hemos dado. Con respecto a la actitud suplicante, Gomme: I, 438, recoge alguna situación semejante en la tragedia, a saber, la del Télefo euripideo, así como su reflejo y parodia en Aristófanes, Ach. 326ss, Thesm. 689ss. Además, el estudioso británico se manifiesta contra quienes han criticado al historiador por un hecho que, para ellos, carece de solidez histórica. A su vez, Hornblower: I, 221, indica que dicha esposa, anónima en el pasaje, es una de las pocas mujeres presentes en la historia tucididea, en contraste con la notable aparición de las mismas en Heródoto.

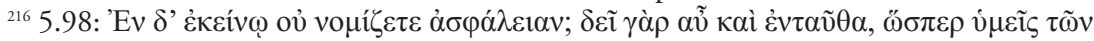

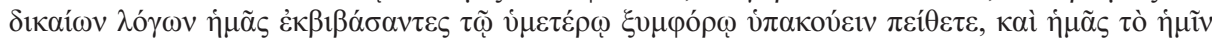

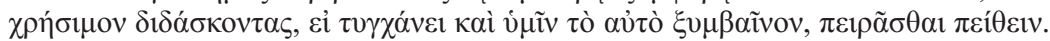

${ }^{217}$ Propio de los debates agonales en el escritor es la pareja «justo»-«conveniente», recogida

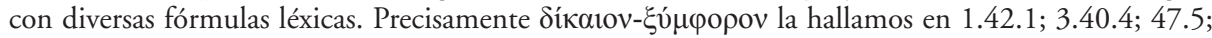

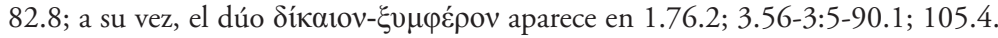


Alargaremos unos discursos bastante extensos, no contra lo acostumbrado, sino que nos resulta propio de nuestro territorio, cuando bastan pocas palabras, no usar muchas, pero enseñar cualquier asunto de importancia con bastantes palabras cuando sea el momento de conseguir lo debido. Acogedlas, no con ánimo hostil ni como si recibierais una lección siendo unos ignorantes, sino considerándolas un recuerdo, ante gentes que lo saben, para tomar bien las decisiones ${ }^{218}$.

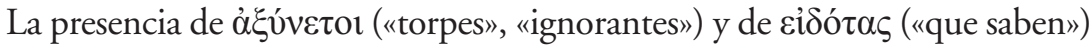
permite pensar, creemos, en el valor de «enseñar», al menos como posibilidad. Además resulta conspicua la oposición semántica $\delta 1 \delta \alpha ́ \sigma \kappa o v \tau \alpha \varsigma / \delta 1 \delta \alpha \sigma \kappa o ́ \mu \varepsilon v o 1$, voz activa / voz media, «dar una lección» / «recibir una lección»; respectivamente, en activa, con objeto directo, y, en media, sin complemento, con sentido absoluto. En el fondo la oposición semántica queda establecida entre quienes enseñan algo (los peloponesios) y quienes aprenden (los atenienses).

5.9. Finalmente un texto nos sitúa en el 431 a. C., dentro de la asamblea convocada en Esparta por los lacedemonios a fin de que quienes se sintieran perjudicados por los atenienses expusieran sus quejas. En tal ocasión los corintios les dijeron a los lacedemonios: "La confianza en vuestro régimen político y en el trato personal os hace, lacedemonios, bastante desconfiados respecto a los demás, si decimos algo. Y por ello mantenéis prudencia, pero utilizáis una ignorancia bastante grande en los asuntos externos. Pues anunciándoos nosotros muchas veces los daños que íbamos a recibir por obra de los atenienses, no aprovechabais el aprendizaje de lo

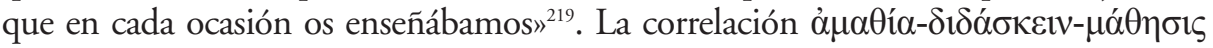
nos parece argumento suficiente para sostener que Tucídides está usando los tres términos dentro del campo de la enseñanza y el aprendizaje. En el plano sintáctico destaquemos algunos detalles: los corintios, en repetidas ocasiones, «trataban de enseñarles» a los lacedemonios unas advertencias que éstos no aprendían; el imperfecto es significativo, pues con frecuencia, como en el caso presente, lleva al pasado

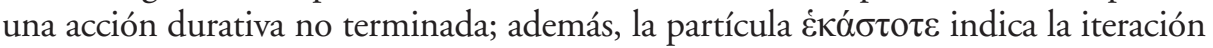
de la acción verbal, rasgo muy propio del «enseñar». Por otra parte el sustantivo

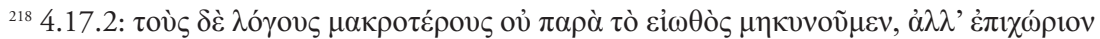

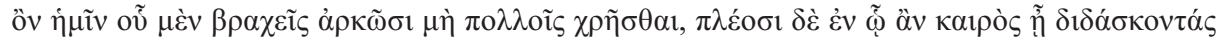

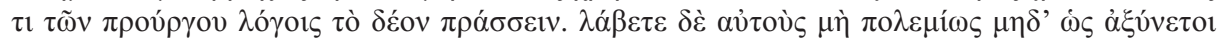

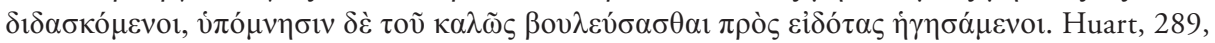

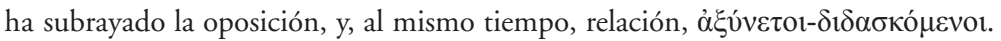

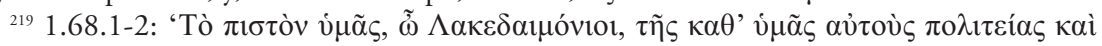

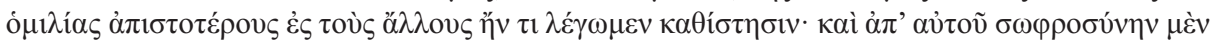

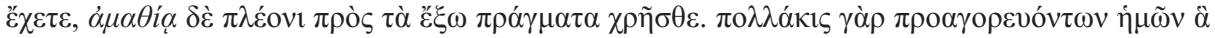

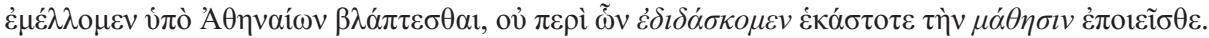
Pongo en cursiva los tres términos relacionados con el campo de la educación. Es un ejemplo de acumulación léxica, constituida con términos del mismo campo léxico. 


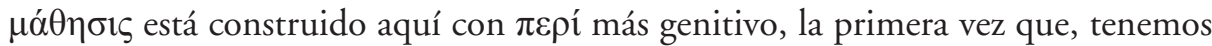
un giro tal en griego, uso sintáctico recogido, años más tarde, por Platón ${ }^{220}$.

\section{6. $\delta 1 \delta \alpha \chi \eta ் ~(4)^{221}$.}

En Tucídides, tres secuencias de ese sustantivo presentan el valor de «admonición», «recomendación $»^{222}$. En cambio, el texto que mencionaremos ahora nos ofrece, creemos, un sentido diferente, pues se establece una oposición polar entre «natu-

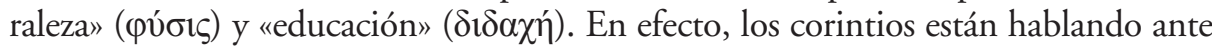
la asamblea de los peloponesios y aliados, celebrada en el 432 a. C., afirmando que son superiores a los atenienses en número y experiencia bélica; tienen el valor, mientras que los atenienses poseen el dinero y la fuerza: «Pues el bien que nosotros tenemos por naturaleza, en aquéllos no podría darse por medio de educación. En cambio, aquello en que ellos sobresalen por su saber, nos resulta conseguible mediante el ejercicio ${ }^{223}$. El historiador, por boca de los corintios, parece establecer una oposición tajante entre la naturaleza y la enseñanza. Lo que unos (los peloponesios y todos sus aliados, incluidos los corintios) tienen por naturaleza, no pueden conseguirlo los otros (los atenienses) mediante la enseñanza, el aprendizaje. Si nos limitáramos a esta lectura, podría parecernos que estamos repasando algunos versos de Píndaro, para quien el noble, el aristócrata, no tiene nada que aprender, todo le es dado por naturaleza. Realmente, en ciertos círculos señoriales, hubo durante el siglo $\mathrm{V}$ una desconfianza total frente a quien adquiriera algo mediante el aprendizaje $\mathrm{e}^{224}$.

Tucídides habla en varios contextos de la "naturaleza humana»" ${ }^{225}$, y, asimismo, de que los hechos volverán a repetirse mientras esa naturaleza sea la misma ${ }^{226}$. Con ello, el escritor parece entrar en una visión cíclica de la historia. Ahora bien, para la historia de las ideas conviene hacer un pequeño excurso en este momento. Para corroborar una línea de pensamiento avanzado, a saber, la que sostiene el progreso

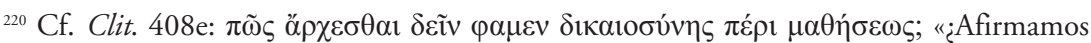
cómo debe comenzar el aprendizaje de la justicia?».

${ }^{221}$ Véase, respecto al sentido, Heródoto, apartado 4.

${ }^{222} 1.120 .2 ; 4.126 .1 ; 126.4$.

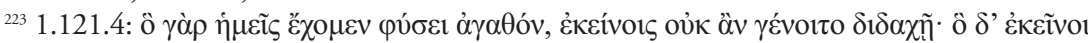

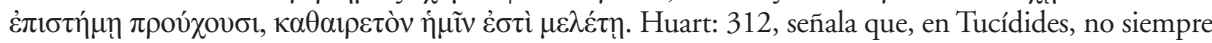

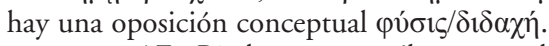

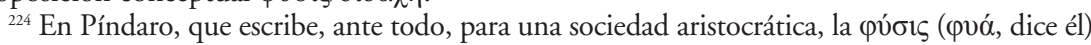
es inmutable; uno es lo que es por nacimiento, sangre o estirpe; no hay posibilidad de cambio: Cf. O. 2.86; 9.100. Este pensamiento lo hallamos reflejado en algunos lugares de Sófocles: Ai. 1259, 1301; Tr. 379; Ant. 727; Ph. 79, 874, 902, 1310. En cambio Demócrito y Eurípides, por ejemplo, hablan de una púøıs que puede cambiar con la educación. Cf. Sunshine, 1964.

${ }^{225} 1.76 .3 ; 2.50 .1 ; 3.45 .7 ; 84.2$.

2263.82 .2 . 
humano, selecciono dos pasajes del último tercio del siglo $\mathrm{V}$ a. C. y uno de unas décadas después. En primer lugar, leemos en Demócrito: «La naturaleza y la educación son algo semejante. Pues también la educación le altera el ritmo al hombre, y, al alterarlo, crea naturaleza ${ }^{227}$. En segundo lugar, dentro de los Tratados hipocráticos, $\varphi v ́ \sigma ı \varsigma_{\text {y }} \delta 1 \delta \alpha \sigma \kappa \alpha \lambda i ́ \eta$ aparecen juntas en alguna secuencia ya vista ${ }^{228}$. Si pasamos a la centuria siguiente, el propio Platón, dentro de un pasaje de las Leyes donde se ocupa de la hípica, alude a las mujeres en estos términos: «Si, a resultas de las enseñanzas anteriores que entran en el carácter, su naturaleza se lo permite y no les produce irritación participar cuando son niñas o muchachas, permítaseles y no se les censure ${ }^{22}$. En esta secuencia podemos advertir que el resultado de la educación $(\pi \alpha 1 \delta \varepsilon v ́ \mu \alpha \tau \alpha)$ contribuye al modo de ser, el carácter, de ciertas mujeres. Resulta, pues, que desde Demócrito, tenemos establecida la idea progresista de que la enseñanza termina por constituirse en una parte de la naturaleza humana.

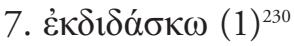

El verbo es conocido desde la lírica del VII a. C.231 y será recogido luego por los trágicos griegos ${ }^{232}$, entre otros. Ya lo hemos visto en Heródoto. Presentaré ahora el único pasaje tucidideo donde dicho vocablo está registrado. Efectivamente, en el invierno del 415-414, tuvo lugar una Asamblea en Camarina (Sicilia), donde, de una parte los siracusanos, con Hermócrates al frente, y, de otra, los atenienses, liderados por Eufemo ${ }^{233}$, intentaban atraerse a los camarinenses a su lado. En tal ocasión, entre otras palabras, Hermócrates ${ }^{234}$ dijo lo siguiente: «Resumiendo, los siracusanos

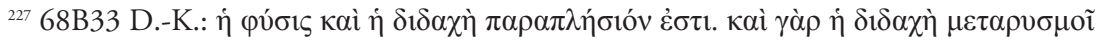

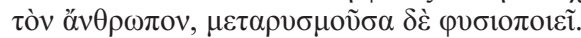

${ }^{228}$ Véase nota 176.

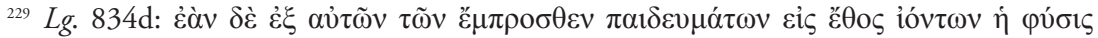

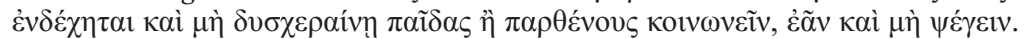

${ }^{230}$ Para el sentido, cf. lo indicado en Heródoto, apartado 5.

${ }^{231}$ Safo (1); ya en el v, Píndaro (1).

${ }^{232}$ Esquilo (2. Ambas apariciones en $\operatorname{Pr}$. Véase 981, donde habla el personaje central: «Mas

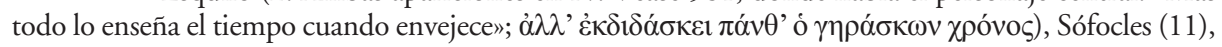
Eurípides (4).

${ }^{233}$ Classen-Steup: VI, 183, sostienen que no se sabe nada sobre el así llamado. Por lo demás, se ha pensado que fuera el homónimo arconte de Atenas (417-416 a. C.). En todo caso, en Tucídides es un enviado de Atenas a Camarina para tal ocasión, y representa (6.81.1) el imperialismo ateniense dentro de la línea más dura (6.82-87).

${ }^{234}$ Famoso siracusano, hijo de Hermón, hábil con la palabra y valeroso en la acción, se opuso a la invasión de los atenienses con tal vigor que sus conciudadanos lo nombraron general para repeler a los enemigos. El historiador lo presenta varias veces pronunciando vibrantes discursos para animar a los siracusanos y sus aliados frente a los invasores, a cuya derrota contribuyó en alto grado. 
decimos que no es necesario instruiros claramente ni a vosotros ni a los demás sobre lo que vosotros conocéis de modo en nada peor. Pero os lo pedimos y damos testimonio a la vez de que, si no os convencemos, somos atacados por jonios siempre enemigos, y resultamos traicionados, siendo dorios, por vosotros, dorios ${ }^{235}$. El esquema según el cual alguien enseña algo a otro tiene aquí una variante, pues el «algo», lo que se enseña, aparece recogido mediante una frase introducida por $\pi \varepsilon \rho i ́$. Además el juego

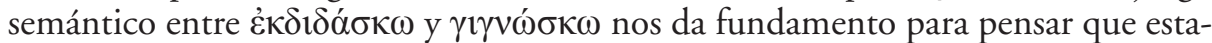
mos en el campo de la enseñanza, pues poco sentido tiene tratar de «enseñarle a fondo" a alguien lo que éste ya sabe. Repárese en que el verbo revisado recibe una precisión modal $\sigma \alpha \varphi \tilde{\omega} \varsigma$, "con claridad», «de modo manifiesto", muy en consonancia con el proceso de la enseñanza, la transmisión de conocimientos. La construcción, usada por primera vez aquí, la recoge siete siglos después Galeno ${ }^{236}$, y tuvo buena acogida en la literatura posterior ${ }^{237}$.

8. $\pi \rho \circ \delta 1 \delta \alpha ́ \sigma \kappa \omega(1)$, «enseñar con anterioridad». En pasiva, «aprender de antemano».

Este verbo aparece en el siglo V. Lo emplean Ferécrates (1 ${ }^{238}$, Sófocles (3) ${ }^{239}$, Aristófanes ${ }^{240}$ y Tucídides. Leemos en las Historias de éste que, durante el invierno del 431-430, tuvieron lugar el entierro y homenaje público de los atenienses muertos en el primer año de la guerra. Pericles, elegido para pronunciar el elogio de los sepultados, subraya el modo de ser de los atenienses en general, $y$, tras afirmar que se preocupan tanto por las actividades personales como por las públicas, pues incluso los dedicados a diversas ocupaciones privadas conocen, y no en grado insufi-

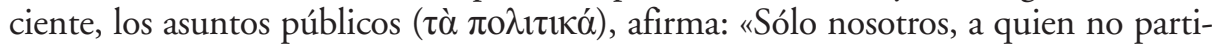
cipa en nada de esos asuntos, lo consideramos, no indiferente, sino inútil, y, personalmente, o juzgamos o nos preocupamos correctamente por las actividades públicas, sin considerar un perjuicio para las acciones, no las palabras, sino, más bien, no haber aprendido de antemano mediante la palabra antes de acudir con la acción a lo que sea preciso» ${ }^{241}$. La secuencia merecería un estudio detenido sobre la oposición

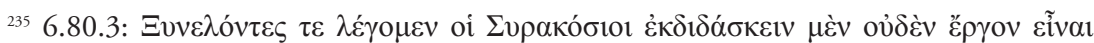

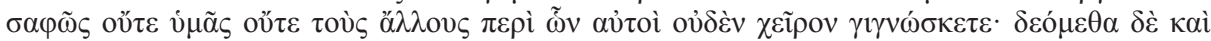

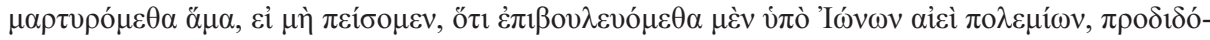

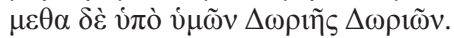

$2369.165 .5 ; 669.14 \mathrm{~K}$.

${ }^{237}$ Eusebio de Alejandría (1), Atanasio de Alejandría (1), Macario de Alejandría (1), Cirilo de Alejandría (3), etc.

${ }^{238}$ El comediógrafo obtuvo el primer premio en la década del 440 a. C.

${ }^{239}$ Una secuencia la hallamos en $A i .163$ (tragedia del 441 a. C. quizá).

${ }^{240}$ Tres usos, pero uno en $N u .476$ (del 423 a. C.).

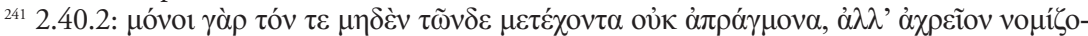

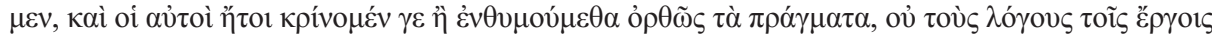

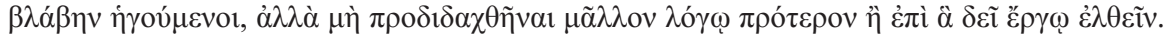




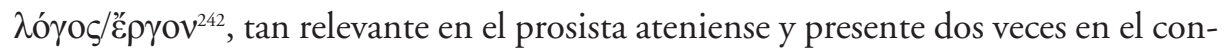
texto seleccionado. La forma verbal que nos interesa $(\pi \rho 0 \delta 1 \delta \alpha \chi \theta \tilde{\eta} v \alpha \imath)$ apunta quizá a la necesidad de tener una información política suficiente por haber acudido a las exposiciones públicas de los oradores. Aun así, respecto a la segunda presencia del primer concepto $(\lambda \hat{\gamma} \gamma \omega)$, creo que no sólo se trata de aprender uno mismo mediante la palabra, el discurso, o, incluso la conversación con otros, sino gracias al razonamiento interior, sentido que el término tiene con frecuencia.

9. $\pi \alpha 1 \delta \varepsilon i ́ \alpha$ (1), «educación», «enseñanza».

El sustantivo aparece en el siglo VI: Teognis (2). Ya en el v lo leemos en Esquilo (1), Eurípides (2), Demócrito (1), Tucídides, Aristófanes (1) y en el tratado hipocrático De arte (1 ${ }^{243}$. Veamos la cita del historiador dentro del que la tradición literaria ha llamado Epitafio de Pericles ${ }^{244}:$ «Y en las acciones educativas, unos, nada más ser jóvenes, con el ejercicio fatigoso ${ }^{245}$ persiguen el valor, pero nosotros, aun viviendo de modo relajado, no menos acudimos a peligros parecidos en el combate ${ }^{246},{ }^{247}$.

\section{${ }^{242}$ Cf. Parry, 1981.}

${ }^{243}$ Jouanna, 1992: 532, lo fecha en el último cuarto del siglo $\mathrm{V}$ a. C.

${ }^{244}$ Así se le conoce desde Platón ( $M x$. 236b) y Aristóteles (Rh. 1365a31). Sobre dicho encomio fúnebre y su función en la obra tucididea, véanse Kakridis, 1961, Flashar, 1969, Ziolkowski, 1981.

${ }^{245}$ En la secuencia nos sorprende la atribución de «ejercicios fatigosos» a los «jóvenes». Desde

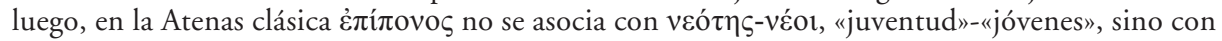
$\gamma \tilde{\eta} \rho \alpha \varsigma_{-} \gamma \varepsilon \dot{\varepsilon} \rho 0 v \tau \varepsilon \zeta$, «vejez»-«ancianos», según nos indica Platón, $R$. 329d. Por otro lado, respecto a presen-

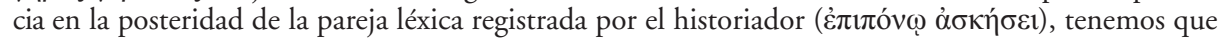
recorrer casi cuatro siglos y llegar a Dionisio de Halicarnaso, quien habla de tres condiciones necesarias para los discursos políticos: «naturaleza apropiada, aprendizaje cumplido, práctica laboriosa» ( $\varphi v ́ \sigma ı \varsigma$

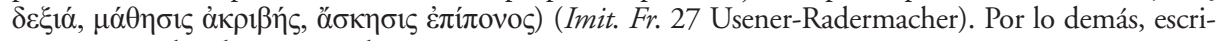
tores más tardíos la recogen alguna vez.

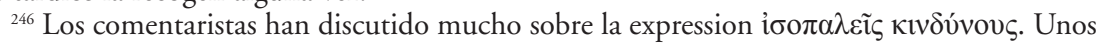
la explican como "peligros iguales», es decir, riesgos semejantes a los afrontados por los espartanos; otros, en cambio, la interpretan como "peligros a los que nuestras fuerzas son suficientemente vigorosas para afrontarlos». Cf. más detalles en Classen-Steup: II, 98; Gomme: II, 117.

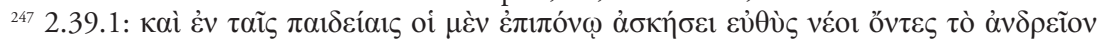

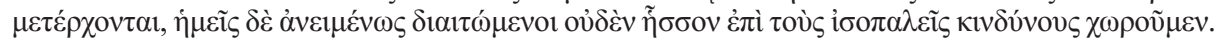
En su edición y comentario del libro II, Rhodes, II 222, explica que en Esparta los niños de siete años eran apartados de sus madres a fin de que comenzaran la agögé, verdadero sistema de ingreso en los ejercicios militares y la vida dura. Nuestro autor nos presenta a Arquidamo, como defensor de su programa educativo (1.84.4). En cambio, en Atenas, durante el siglo V, sólo había posibilidades para la preparación voluntaria en ejercicios bélicos; escasean los datos en dicho periodo sobre la formación de los adultos con tal finalidad. Ahora bien, a partir del 330 se organizó el sistema ateniense de la preparación de los ě de prestar al Estado dos años obligatorios de servicios, en los que destacaban los ejercicios de carácter militar y guerrero. 
El plural de $\pi \alpha 1 \delta \varepsilon i ́ \alpha(\pi \alpha \imath \delta \varepsilon i \alpha \iota)$ puede entenderse como «métodos educativos", pues, al tratarse de un abstracto, el plural suele comportar, en ocasiones, un matiz intensivo-iterativo: "cada uno de los actos de la $\pi \alpha 1 \delta \varepsilon \varepsilon^{\prime} \alpha{ }^{248}$.

10. $\dot{\alpha} \pi \alpha 1 \delta \varepsilon v \sigma i ́ \alpha$ (2), «carencia de educación».

Dentro de la familia léxica de $\pi \alpha \imath \delta \varepsilon v ́ \omega$ me detengo ahora en $\dot{\alpha} \pi \alpha \imath \delta \varepsilon v \sigma i ́ \alpha$, registrada dos veces en Tucídides. Posteriormente, Platón le da más importancia al término ${ }^{249}$. El sustantivo compuesto, dotado de $a$ - privativa, nace en el siglo V. Demócrito es el primero en registrarlo: «sueños ${ }^{250}$ diurnos indican perturbación del cuerpo, inquietud del alma, pereza o falta de educación $»^{251}$.

10.1. En el historiador, Diódoto ${ }^{252}$, ante la Asamblea ateniense, se manifiesta contra el demagogo Cleón, oponiéndose a la ejecución de todos los mitilenios por haberse sublevado contra el imperio de Atenas; ganó la votación, que anulaba la terrible decisión tomada anteriormente. Un navío salió a toda prisa de la ciudad y llegó a Mitilene (en la isla de Lesbos) justo a tiempo de evitar la muerte de quienes no eran responsables de la insurrección ${ }^{253}$. El autor nos transmite los puntos esenciales de su intervención: «Ni acuso a quienes de nuevo han propuesto debate sobre los mitilenios ${ }^{254}$, ni alabo a quienes censuran que se delibere muchas veces sobre los

${ }^{248}$ Lasso de la Vega, 249.

${ }^{249}$ Lo registra 14 veces.

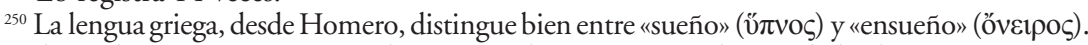
Piénsese en derivados respectivos como «hipnosis», «hipnotizar», y, de otro lado, la «oniromancia». Las lenguas europeas más extendidas también tienen vocablos diferentes para aludir a ambos conceptos (inglés: sleep-dream; francés: sommeil-songe (rêve); alemán: Schlaf-Traum; italiano: sonno-sogno; etc. Recordemos el latín: somnus, $-i$ frente a somnium,-a, y el verbo somnio,-as,-are); en español, en cambio, aunque disponemos de «ensueño», «ensoñación», «ensoñador», solemos usar «sueño» con los dos valores: "tengo mucho sueño", pero también, «he tenido un sueño horrible».

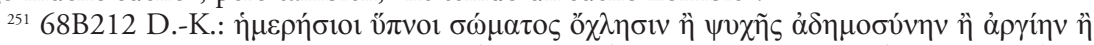
$\dot{\alpha} \pi \alpha 1 \delta \varepsilon v \sigma i ́ \eta v \sigma \eta \mu \alpha i ́ v o v \sigma ı$. (Fragmento transmitido por Estobeo, 3.6.27). De acuerdo con otros datos el atomista Demócrito se preocupó de los sueños y ensueños (Cf. 68A136, 137 D.-K). Realmente, su maestro, Leucipo, había dicho ya que «el sueño del cuerpo acontece a causa de una pérdida de la parte sutil, mayor que la entrada de calor vital; el exceso de dicha pérdida es causa de la muerte. Esos ( $s c$.

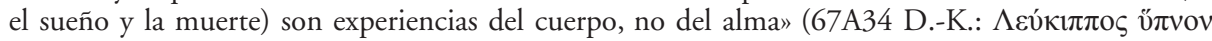

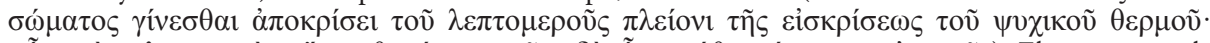

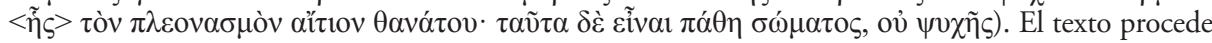
de Aecio, 5.25.3.

${ }^{252}$ Cf. nota 186. Recordemos que el discurso es pronunciado en el 427 a. C.

${ }^{253}$ Con respecto a los más culpables, leemos, en 3.50.1, que Paquete envió a Atenas un número algo inferior a mil. Los atenienses los ejecutaron siguiendo el criterio de Cleón.

${ }^{254}$ En 3.36.1, cuando las naves atenienses trajeron a Atenas a varios mitilenios presuntamente

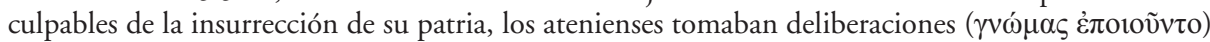
y decidieron matarlos a todos, y, además, a todos los de la isla, así como vender como esclavos a mujeres y niños. A tal efecto enviaron una trirreme dándole órdenes al general Paquete para que las ejecutara rápidamente. 
asuntos más importantes, y pienso que dos son las actitudes más opuestas a la prudencia: precipitación y apasionamiento ${ }^{255}$, de los cuales, la una ${ }^{256}$ suele darse junto a la insensatez, y el otro, junto a la falta de educación y la cortedad de criterio» ${ }^{257}$. En Tucídides, dentro de esta secuencia, el sustantivo ỏ $\pi \alpha 1 \delta \varepsilon v \sigma i ́ \alpha$ debe entenderse, pensamos, como «falta de educación» con un valor finitivo, resultativo: «carencia de preparación, de instrucción»; no alude, en cambio, a ningún error ni exceso relacionados con un comportamiento inadecuado.

10.2. El otro texto al que aludíamos lo hallamos en el famoso capítulo 84 del libro tercero, atetizado ${ }^{258}$ por algunos gramáticos antiguos, y no mencionado por Dionisio de Halicarnaso, buen conocedor del estilo tucidideo. Todavía hoy no hay acuerdo entre los especialistas sobre si dicho capítulo es auténtico o espurio, por lo que puede afirmarse que sigue siendo una cuestión literaria abierta ${ }^{259}$. Recordemos brevemente la situación histórica y política. Las luchas civiles tuvieron lugar en la isla de Corcira con especial crueldad en el 427 a. C., como un adelanto de los terribles sucesos que ocurrirían posteriormente durante la guerra del Peloponeso.

${ }^{255}$ Huart, 175 ss, ha visto bien que, dentro del vocabulario psicológico tucidideo, ó $\gamma \eta \dot{~}$ ocupa un lugar relevante. El sustantivo lo tenemos a partir de Hesíodo: «manera de ser», «comportamiento»; pero ya en Semónides (7.11 West) es utilizado para describir el comportamiento cambiante de la mujer, con lo que adquiere connotaciones abiertamente negativas. Recordemos que los versos de dicho poeta tuvieron notable influencia en la literatura posterior. En Tucídides, que usa el citado sustantivo 41 veces (más otras 19 el verbo ỏ $\gamma^{\prime} \zeta_{\zeta} \mu \alpha 1$ ), el espectro semántico abarca desde el «ardor» y la «pasión» hasta la «cólera».

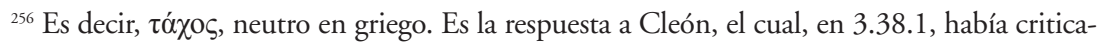

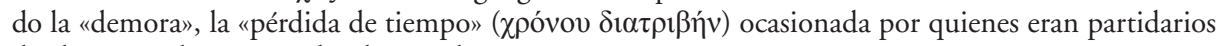
de abrir otra discusión sobre los mitilenios.

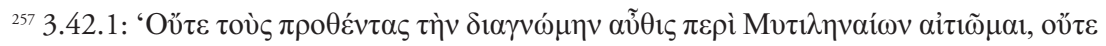

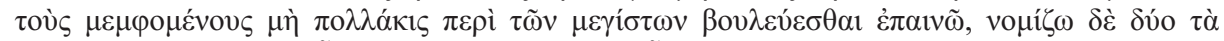

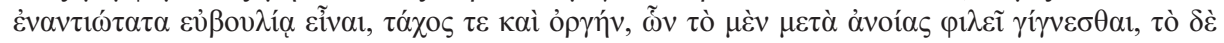

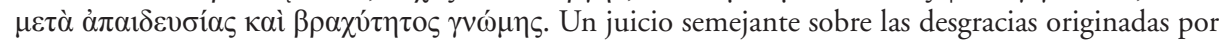
quien no tiene educación está recogido en el Fr. 523 de los Adespota Tragica de Nauck: «muchos son

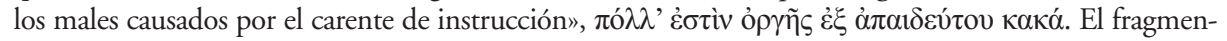
to fue recogido por Estobeo, 3.20.12b. Véase más información en Classen-Steup: III, 82.

${ }^{258}$ Las razones esenciales para considerer espurio el capítulo han sido cuatro: el códice F (Monacensis 430 del siglo XI) lo marca como tal; un escolio al pasaje afirma que ninguno de los comentaristas lo tuvo por auténtico, sino que lo consideraron oscuro por el modo de la interpretación e indi-

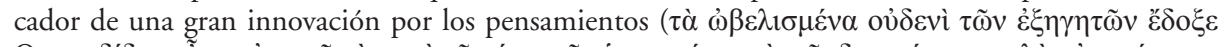

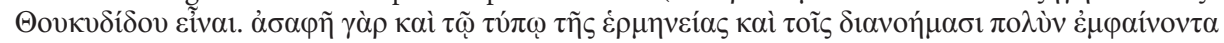

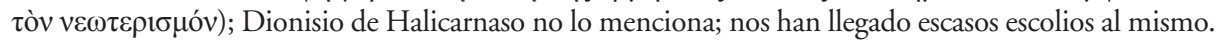
Cf. Classen: II, 382-386, lo tiene por espurio, pero ve en él una buena imitación de Tucídides, e imitado a su vez por Josefo (AI 17.191); Hornblower: I, 488-489, que recoge argumentos en pro y en contra de mantenerlo como auténtico, aunque se inclina por verlo como espurio.

${ }^{259}$ Christ, 1989, ofrece una lista de detractores y defensores del mismo, con las razones principales esgrimidas por cada uno. 
El historiador recoge con sumo cuidado los horrores de la revolución ${ }^{260}$, y advierte con especial acribia cómo durante la revolución se alteró profundamente el significado normal de las palabras. Para cualquier lingüista el testimonio histórico al que aludimos posee indudable importancia. Recordemos que, según leemos en el ateniense, la crueldad llegó a tales excesos que los partidos políticos se mostraron más fuertes que los lazos de sangre. Dejemos para otros el problema de la autoría y leamos el párrafo que nos interesa:

Pues bien, en Corcira, los más de esos hechos fueron cometidos previamente con osadía, tanto cuantos realizan los que, siendo dominados por desmesura más que por moderación, se vengan de quienes les pagan el castigo, y, asimismo, algunos, queriendo liberarse de la pobreza habitual y, sobre todo, deseando, a causa de su padecimiento, poseer lo de los vecinos, los deciden contra justicia; y también cuantos emprenden otros, no por ambición, sino partiendo generalmente de una situación de igualdad, pero arrastrados en sumo grado por la falta de instrucción de su cólera ${ }^{261}$.

El giro en cursiva equivaldría a una oración causal: por no tener controlada, educada, su pasión, su arrebato. En todo caso, -a nuestro juicio-ỏ $\rho \gamma \tilde{\eta} \varsigma$ es un genitivo subjetivo, entendido el sustantivo como personificado: «la cólera carece de educación». Los comentaristas se ven en apuros al explicar el texto. También vacilan los diccionarios usuales ${ }^{262}$. En todo caso es importante subrayar la idea recogida en el pasaje: los afectos e impulsos del espíritu pueden regularse mediante la educación. El pensamiento tendrá buena acogida en la literatura helenística e imperial ${ }^{263}$.

\footnotetext{
${ }^{260} \mathrm{~A}$ las citadas luchas civiles corresponde lo que decíamos sobre la guerra entendida como dura maestra.Véase el pasaje recogido en nota 190.

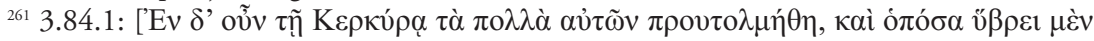

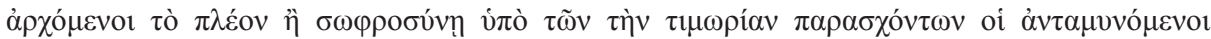

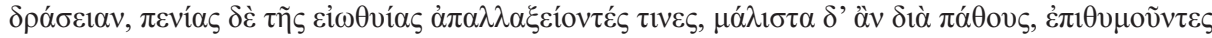

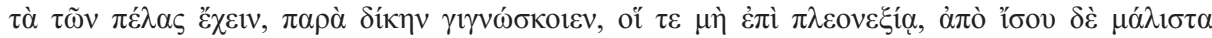

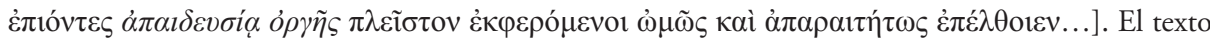
que seguimos ofrece el capítulo como espurio, de ahí el corchete vertical puesto al comienzo y final de la secuencia. Classen-Steup: III, 173, piensan que el capítulo es producto de las reflexiones de un moralista tardío sobre los dos capítulos precedentes. En torno a los sucesos de Corcira, véase Wilson, 1987.

${ }^{262}$ Véanse, por ejemplo: Bailly: 199: «impuissance à maîtrisser», o lo que es lo mismo, «incapacidad para dominar»; LSJ: 175: «from bigotry of passion», equivalente a "por intolerancia de la pasión»; $D G E$ : II 372: «falta de dominio»; etc.

${ }^{263}$ La correlación entre ỏ $\rho \gamma \eta ́$ y $\alpha \dot{\pi} \alpha \iota \delta \varepsilon v \sigma i ́ \alpha$, vista en el texto de la nota 257 (3.42.1), aparecería, pues, dos veces en el historiador, en caso de tener por auténtico el capítulo que estamos revisando. El TLG la registra en dos escritos tardíos: las Epistulae de virginitate (1.11.6) atribuidas erróneamente a Clemente Romano, y el Contra Eunomium (1.1.648) de Gregorio de Nisa. Respecto a la correspondencia entre ỏ $\gamma \eta \dot{~ y ~ a ̉ đ \alpha i ́ \delta \varepsilon v \tau o \varsigma ~ c o n t a m o s ~ c o n ~ m a ́ s ~ c o n t e x t o s: ~ J o s e f o, ~ A I ~ 19.175 ; ~ P l u t a r c o, ~ S o l . ~ 21 ; ~ e t c . ~}$
} 


\section{1. $\pi \alpha i ́ \delta \varepsilon v \sigma ı(1)$}

Si volvemos al famoso Epitafio tucidideo ${ }^{264}$, en boca de Pericles leemos lo siguiente: «Y, resumiendo, digo que la ciudad entera es modelo educativo de la Hélade, y, me parece que, uno por uno, el mismo hombre de entre nosotros puede presentar una personalidad autosuficiente en muchísimos aspectos y dotada de gracias, con donaire en sumo grado ${ }^{265}$.

A mi entender, estamos ante algo diferente de la mera acción, valor normal de tantos nombres en - $\sigma i s$. En realidad, es preferible entender el vocablo como un resultado y un modelo: Atenas ha llegado a ser la escuela del resto de la Hélade. El pasaje ha sido muy estudiado y discutido, y los estudiosos han prestado especial atención al sustantivo que examinamos ${ }^{266}$. Por lo demás, la secuencia encierra indudables dificultades sintácticas y estilísticas. No es la menor el uso de ő้ $v$, pues no acompaña a muy lejos, y, de ahí, la necesidad de reforzarlo sucesivamente. En pasajes tucidideos muy elaborados no es rara la repetición de dicha partícula hasta tres veces con el mismo verbo $^{267}$. Además, quizá convenga repasar algún punto sintáctico con el propósito de

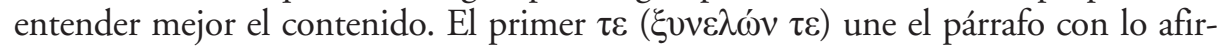
mado anteriormente en la secuencia; el segundo $(\tau \eta ́ v \tau \varepsilon)$ va en correspondencia con $\kappa \alpha i ́$. Ambos introducen miembros de enorme relieve: el primero, la ciudad; el segundo, el individuo. En cuanto a $\pi \tilde{\alpha} \sigma \alpha v$, conviene subrayar su valor total, absoluto: la ciudad "por completo», «en su totalidad»; en cambio, $\kappa \alpha \theta$ ' ह̌ $\kappa \alpha \sigma \tau o v$ tiene un sentido distributivo: «uno a uno», «uno por uno». Nótese la antítesis: la ciudad a diferencia del ciudadano; la totalidad frente a la individualidad. Dentro de la predicación antinómica (asignar a una persona o cosa cualidades que en la vida corriente son polarmente distintas) tan propia del Epitafio, destaca aquí la atribución al hombre,

${ }^{264}$ Cf. nota 244.

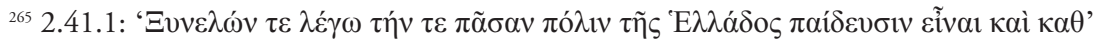

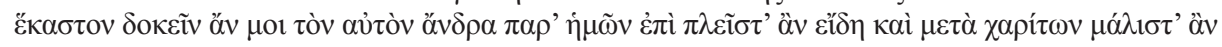

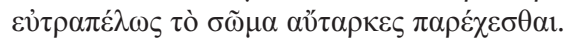

${ }^{266}$ "A school of the Grecians» («una escuela de los griegos», Hobbes: 195. Se trata de Thomas Hobbes, el autor del Leviatán, traductor de Tucídides y buen conocedor de su pensamiento); «the school of Hellas» («la escuela de la Hélade», Jowett: 120), «an exemple to Greece» («un ejemplo para Grecia», Hornblower, I, 308); «une vivante leçon» («una lección viva», Romilly: I, 30), «la escuela de Grecia», Adrados: I, 258), «an education to Greece», («una educación para Grecia» Rhodes: II, 224). En la misma línea de pensamiento, leemos en Platón (Prt.337d) que Atenas viene a ser «el pritaneo de la sabiduría» ( haberse convertido, de modo razonable, en maestra de todo lo que se pueda decir o enseñar» (ő $\tau$ đóv $\tau \omega \nu$

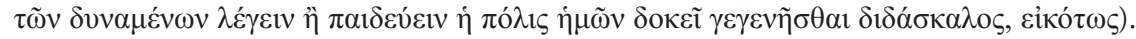

${ }^{267} 2.93 .3 ; 4.18 .4 ; 29.3 ; 6.10 .4 ; 14.1 ; 34.5$ (4 apariciones); 34.6 (4); 35.1; 49.2 (4); 64.1; 7.42.3 (4); 77.4; 8.96.4 (4). Nótese en el libro sexto la cantidad de registros. 
a cada uno de los atenienses - entiéndanse, los ciudadanos con derecho a voto- condiciones excelentes en grado sumo, tanto en lo moral (las gracias, que pueden ser morales, pero también físicas) como en lo puramente físico -el modo ágil aludido por

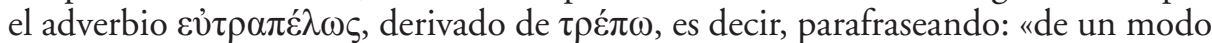
en que se da la vuelta fácilmente, de modo ágil, con donaire»-. Realmente, el historiador está jugando con dos tipos de predicación: la antinómica, ya expuesta, y la superlativa. Consiste ésta en atribuir condiciones en sumo grado: «el mejor», «el que más», «el único». Las dos notas superlativas están indicadas por dos giros asimismo superlativos: el acusativo plural neutro $\pi \lambda \varepsilon \tau \tilde{\sigma} \tau \alpha$ (de $\pi \mathrm{o} \lambda \hat{\jmath} \varsigma$ ) que califica numéricamente a $\varepsilon^{\prime} \delta \eta \eta$, los aspectos, formas o posiblidades, y, en segundo lugar, el adverbio en grado

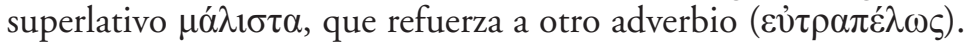

Al hilo del pasaje tucidideo, permítasenos hacer un excurso con respecto al sustantivo que estamos revisando. Basándonos en los datos ofrecidos por la edición de los Presocráticos de Diels-Kranz, podemos afirmar que dentro del corpus allí recogido sólo tenemos, con seguridad, dicho vocablo en dos ocasiones, precisamente dentro del mismo fragmento de Antifonte ${ }^{268}$. Si el pasaje corresponde a Antifonte de Ramnunte, podríamos pensar en el ilustre orador citado por Tucídides con palabras muy positivas ${ }^{269}$ : fue el cerebro de los llamados Cuatrocientos, los que en el 411 dieron un golpe de estado e implantaron un régimen abiertamente oligárquico. Antifonte, a pesar de que se defendió de sus acusadores con toda brillantez, fue condenado y ajusticiado en el citado año. Así pues el fragmento que vamos a ver tiene que ser anterior a esa fecha, si pertenece al ramnusio: «Pienso que lo primero en los hombres es la educación. Pues cuando se hace correctamente el comienzo de cualquier asunto, es natural que también el final sea correcto. En efecto, del mismo modo que uno siembra la semilla, así es necesario esperar la cosecha. Y cuando uno siembra en un cuerpo joven la verdadera educación, eso vive y florece a lo largo de toda la vida, y no lo destruyen ni la lluvia ni la sequía ${ }^{270}$. Por lo que hace al sustantivo que nos interesa,

${ }^{268}$ Una cuestión literaria todavía no resuelta es si hay un Antifonte o dos: el de Ramnunte (orador y político) y el llamado «sofista», al que Jenofonte presenta en medio de una discusión dialéctica con Sócrates (Mem. 1.6.1-15). Entre otros personajes homónimos hay un tercer Antifonte, el llamado «trágico», que vivió en Siracusa, precisamente en la corte del tirano Dionisio I, y es citado en varios lugares por Aristóteles.

${ }^{269} 8.68 .1$.

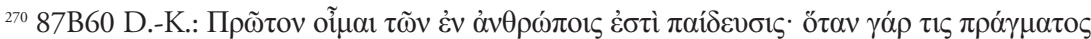

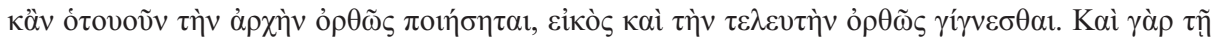

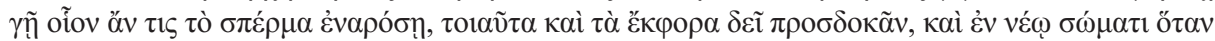

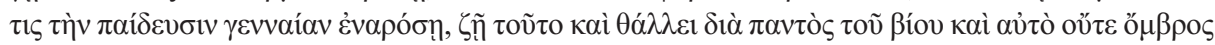

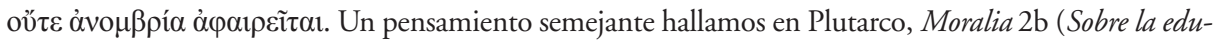
cación de los niños 4): «La naturaleza se parece a la tierra, el educador, al agricultor, y los consejos verba-

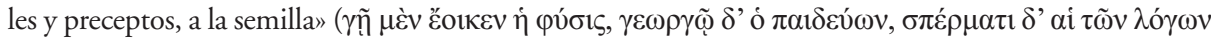

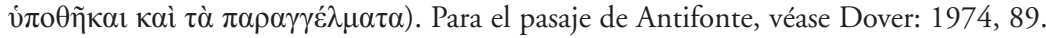


podemos pensar que se trata del momento incipiente de la educación; el comienzo mismo de la acción educativa. Por su lado, el adjetivo yevvaĩos, «verdadero», «noble», «auténtico», «legítimo», atribuido a cosas, podría apuntar a la existencia de otra educación que fuera innoble, baja, falsa, espuria, ilegítima. En lo que a nosotros nos afecta, es difícil sacar más consecuencias de dicho fragmento.

Pero volvamos ya al gran historiador ateniense a propósito de $\pi \alpha i ́ \delta \varepsilon v \sigma ı \varsigma$. En efecto, Tucídides es un buen modelo para el estudio de los sustantivos abstractos en $-s^{25^{71}}$. En numerosos ejemplos, ofrece el sentido habitual de esos sustantivos de

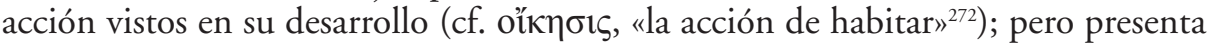
también abundantes secuencias en que los nombres dotados del mencionado sufijo indican ya el resultado, la realidad concreta, plena, indicada por la idea verbal: piénse-

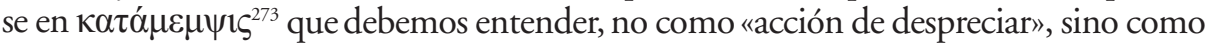
«motivo, resultado de desprecio». Esta evolución semántica del sufijo -sis comienza en Heródoto y acaba siendo normal en la koiné. En esta línea de cambio del signifi-

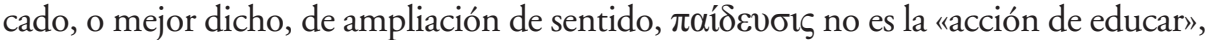
sino «el resultado de educar» (el «modelo educativo») e incluso, por metonimia, el lugar donde se imparte la citada educación, es decir, «la escuela». El encomio tucidideo de la ciudad de la Acrópolis fue punto de partida de otros elogios de Atenas. En el epitafio de Eurípides ${ }^{274}$, que, para algunos, fue escrito por el propio historiador,

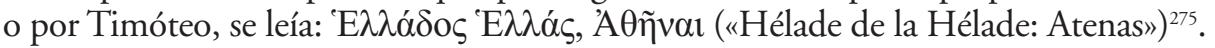

\section{2. $\pi \alpha 1 \delta \varepsilon v ́ \omega(2)^{276}$}

Las dos apariciones de este verbo en Tucídides aparecen en boca del rey Arquidamo $^{277}$, se refieren a los lacedemonios y están en pasajes muy próximos. El sentido del verbo es ya más amplio que el que veíamos en Heródoto, donde, como dijimos, está ligado al sentido etimológico, el «niño». En el prosista ateniense, en cambio, la voz media no va acompañada de indicaciones sobre la edad en que uno ha recibido la educación.

\footnotetext{
${ }^{271}$ Se ha visto, por ejemplo, la preferencia del general espartano Brásidas por tales sustantivos: cf. Francis, 1991-1993.

272 2.16.1.

2732.41 .3 .

${ }^{274}$ En realidad se trata de una inscripción funeraria, sepulcral, no una alocución pronunciada en elogio de quienes habían muerto en defensa de la patria, como hemos visto en el caso del famoso Epitafio tucidideo. Para un examen actual sobre dicha inscripción, cf. Plant, 2015.

${ }^{275}$ Cf. AP 7.45.3. Véase Vita Euripidis 1.

${ }^{276}$ Véase lo que decíamos en Heródoto, apartado 10.

${ }^{277}$ Rey de Esparta entre los años 469-427 a. C. En el 462 logró terminar la guerra de Mesenia con la ayuda de Atenas. Tuvo fama de inteligente y prudente (1.79.2) y fue amigo y huésped de Pericles (2.13.1). Partidario de evitar la guerra del Peloponeso, invadió el Ática en el 431 (2.19.1), y en el 427 se apoderó de Platea, después de dos años de sitio.
} 
12.1. En la primera secuencia leemos lo siguiente ${ }^{278}:$ «Y, gracias a la buena disposición, somos batalladores y prudentes: lo uno porque el pundonor participa muchísimo de la moderación, y la valentía, de la vergüenza; y, de otro lado, prudentes, por ser educados con un grado de ignorancia ${ }^{279}$ mayor que el menosprecio de las leyes, $y$, a pesar de la dureza, de forma bastante moderada como para desobedecerlas ${ }^{280}$. Por lo que a nosotros se refiere hay una íntima relación entre $\alpha \mu \alpha \theta \varepsilon \dot{\delta} \sigma \tau \rho \rho \nu$ y $\pi \alpha 1 \delta \varepsilon v o ́ \mu \varepsilon v o t$, pues si el primero apunta al estado propio de una ignorancia bastante elevada, resultado evidente de no haber aprendido, el segundo aporta la noción de «ser educados», «recibir enseñanza». A su vez, los acusativos adverbiales ( $\alpha \mu \alpha \theta \varepsilon \dot{\varepsilon} \sigma \tau \varepsilon \rho o v-$

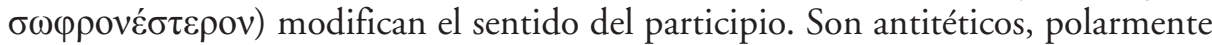
opuestos: la rudeza propia de la ignorancia se contrapone a la actitud que corresponde a la prudencia. De ambos adjetivos dependen sendos segundos términos de la comparación: el primero en genitivo ${ }^{281}$; el segundo introducido mediante la partícula $\eta$. Nuestro autor, como en tantas otras ocasiones, se muestra experto en la variatio sintáctica y léxica ${ }^{282}$. Desde los escoliastas la construcción que nos interesa ha planteado problemas de interpretación. Los escolios nos ofrecen dos vías posibles para comprender el mensaje: «somos educados para ser ignorantes respecto a menospreciar las leyes; es decir, no somos educados para despreciar las leyes» ( $\pi \alpha 1 \delta \varepsilon v o ́ \mu \varepsilon \theta \alpha$

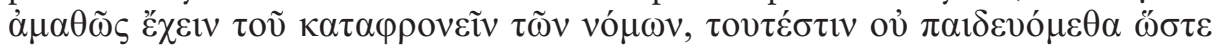
$\dot{v} \pi \varepsilon \rho \circ \rho \tilde{\alpha} v \tau \tilde{\omega} v$ vó $\mu \omega v)$.

12.2. Siguiendo en el mismo capítulo, oímos estas palabras: «Y no se debe pensar que un hombre difiere mucho de otro hombre, sino que el más fuerte es el que se educa en condiciones muy exigentes $»^{283}$. En el dativo con $\dot{\varepsilon} v$ puede pensarse ora

${ }^{278}$ Sobre la Asamblea celebrada en el 431 a. C, véase el apartado 5.9.

${ }^{279}$ Dentro del léxico relacionado con la raíz math-, manth- diremos que, tras revisar en Tucí-

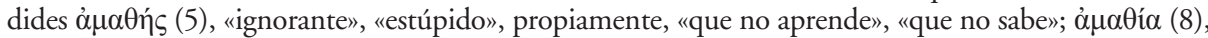
«ignorancia, estupidez»; y $\alpha \mu \alpha \theta \tilde{\omega} \varsigma$ (1), «con ignorancia», sólo he hallado dos contextos relacionados con la educación en sentido amplio. Uno es el que estamos viendo; el otro es el incluido en la nota 219. Añadamos que la expresión $\dot{\alpha} \mu \alpha \theta \dot{\varepsilon} \sigma \tau \varepsilon \rho 0 \imath \mu \bar{\varepsilon} v \tau \tilde{\omega} v$ vó $\mu \omega v$, «más ignorantes que las leyes» la hallamos en boca de Cleón (3.37.4) para incidir en que los hombres bastante ignorantes gobiernan mejor las ciudades que quienes son más inteligentes, pues aquellos aceptan ser más ignorantes que las leyes, mientras que éstos quieren mostrarse más sabios que ellas.

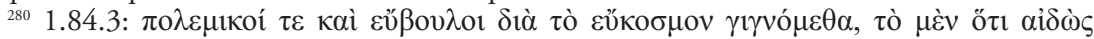

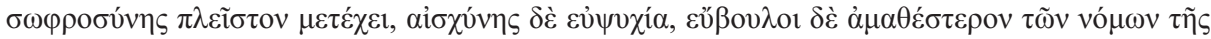

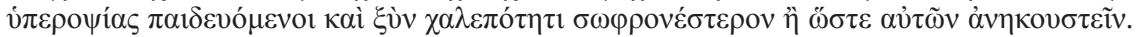

${ }^{281}$ Classen-Steup: I, 235, interpretan $\tau \tilde{\omega} v v$ vó $\mu \omega v \tau \tilde{\eta} \varsigma$ vं $\pi \varepsilon \rho \psi \psi i ́ \alpha \varsigma$ como equivalente a un infinifivo consecutivo-final: "como para menospreciar las leyes».

${ }^{282}$ Sobre la variatio en el historiador ateniense, cf. Ros, 1968. Por su parte, los escolios, recogidos por Hude (1927), son ofrecidos ahora en internet y en el TLG.

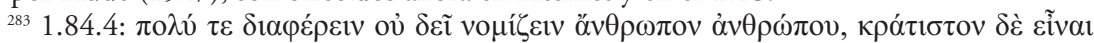

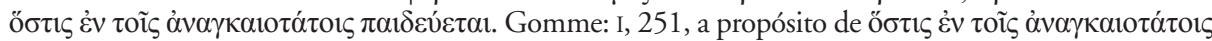

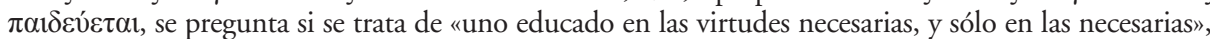
o «uno educado en la escuela más dura», y añade que Arquidamo habría afirmado que las dos posibilidades conducían al mismo resultado. 
en el espacio temporal durante el que se recibe la educación, ora en un valor intrumental, referido a las duras exigencias con las que dicha educación se impartiría. El adjetivo en grado superlativo, masculino, sustantivado, deja abierta la posibilidad

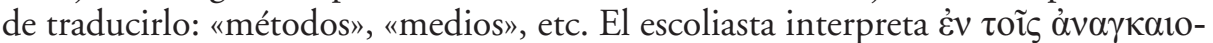

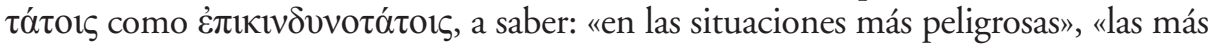
arriesgadas».

13. $\dot{\alpha} \mu \alpha \theta i ́ \alpha(8)$, «ignorancia», «estupidez».

El sustantivo aparece en el siglo VI, pues lo tenemos en los fragmentos de Heráclito (2). Luego, en el v, lo encontramos en Demócrito (1), Sófocles (1), Eurípides (20), Tratados hipocráticos (6), etc. En el IV destaca, sobre todo, Platón (97). De los ejemplos tucidideos hemos encontrado uno, ya recogido, en relación con el campo léxico que venimos examinando ${ }^{284}$.

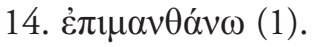

Este verbo es de uso muy restringido, como hemos adelantado al ocuparnos de Heródoto ${ }^{285}$. Tucídides nos ofrece un texto en donde dicho término aparece en relación con $\pi \rho \mu_{\alpha} \alpha v \theta \alpha ́ v \omega(1)^{286}$. Hablando de Temístocles, el historiador lo describe de la siguiente manera: «Pues Temístocles, tras haber demostrado de modo muy firme la fuerza de su naturaleza, era digno de ser admirado por ello de modo diferente y en grado mayor que otro. Por inteligencia natural, sin haber estudiado antes nada ni aprendido despuées ${ }^{287}$ en relación con ella ${ }^{288}$, respecto a los asuntos del momento, mediante rapidísima deliberación, el mejor juzgador, y, respecto a los futuros, en la mayor parte de lo que habría de suceder, conjeturador óptimo» ${ }^{289}$.

${ }^{284}$ Cf. el pasaje recogido en nota 219 . Huart: $279,289,429,472,473$, revisa varios aspectos del término dentro de su estudio del vocabulario de tipo psicológico.

${ }^{285}$ Véase Heródoto, apartado 12.

${ }^{286}$ Huart: 278 , lo contrapone a $\pi \rho \mu_{\alpha} \boldsymbol{\theta} \theta \alpha \dot{v} \omega$, que figura el primero, y los entiende como «études préalables et études postérieures», señalando que se establece una oposición de ambos respecto

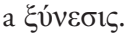

${ }^{287}$ Cf. Classen-Steup: I, 355 indican que $\pi \rho 0 \mu \alpha \theta \omega ́ v$ habría que entenderlo referido a la vida

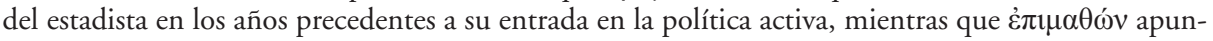
taría a lo aprendido tras haberse incorporado a la misma. Hornblower, I, 223, entiende ambos verbos como «sin ningún estudio ni en el tiempo anterior ni en aquel momento».

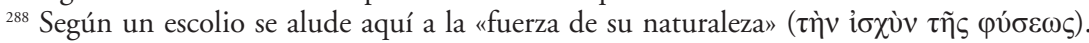

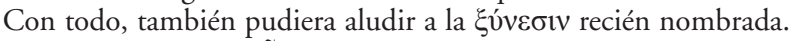

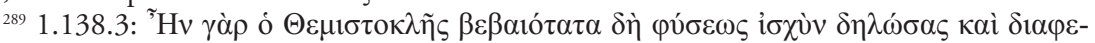

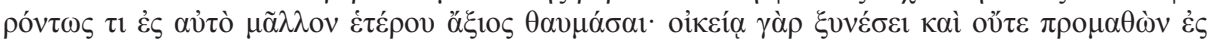

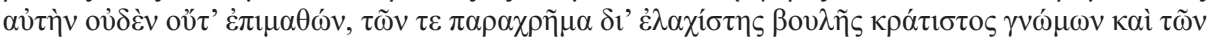

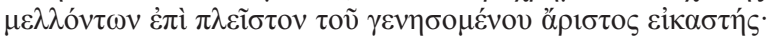


Recojo el ejemplo porque roza la esfera del aprendizaje, aunque, a decir verdad, apunta más bien a la falta del mismo, pues las extraordinarias condiciones del estadista le nacían como algo espontáneo, por obra de su propia naturaleza.

15. $\mu \alpha \dot{\theta} \theta \mu \alpha(1)$.

Cuando revisábamos a Heródoto ${ }^{290}$ ya vimos que este sustantivo adquiere en Tucídides un sentido claramente activo, valor que recogerán en la centuria siguiente Isócrates, Platón y Aristóteles, entre otros.

Veamos la única aparición dentro del ateniense, donde lo hallamos en boca de Pericles: «Pues ofrecemos una ciudad accesible, y, en ningún momento, mediante expulsión de extranjeros, le impedimos a nadie ni el estudio ni la contemplación -de lo que no haya sido ocultado, pues cualquier enemigo podría obtener un beneficio al verlo-, confiados no más en los preparativos y añagazas que en el valor procedente de nosotros mismos para las acciones ${ }^{291}$. Por el contexto tucidideo cabe afirmar que quien llegaba a Atenas tenía libertad para estudiar y contemplar todo aquello que, por razones especiales, no estuviera vedado al público. El vocablo que nos interesa tiene, pues, un valor activo (la adquisición de conocimientos), no pasivo (el conocimiento ya adquirido). Precisamente ese sentido activo lo tenemos también en varios ejemplos de Platón ${ }^{292}$.

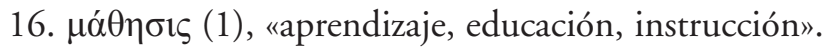

El único pasaje lo hemos examinado al revisar el verbo $\delta 1 \delta \alpha ́ \sigma \kappa \omega^{293}$.

${ }^{290}$ Véase Heródoto, apartado 13.

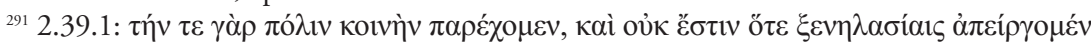

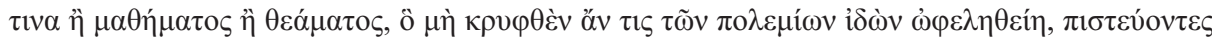

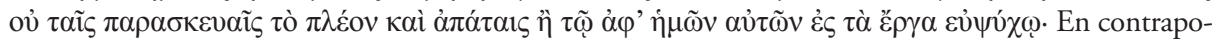
sición a este modo abierto de tratar al llegado de fuera, diversas fuentes nos hablan del régimen cerrado de los peloponesios. Citaré dos ejemplos entre muchos. En uno, el propio Tucídides señala las dificultades que tenía para enterarse de distintos asuntos lacedemonios, pues ni siquiera le fue posible saber el número de combatientes antes de la batalla de Mantinea (418 a. C.), entre argivos y peloponesios, a

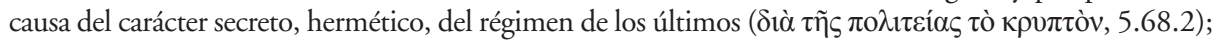
en otro, Aristófanes $(A u .1012)$ indica que los lacedemonios expulsaban a los extranjeros. Además,

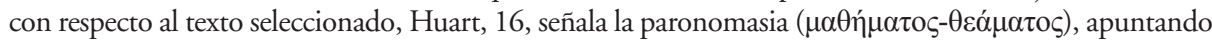

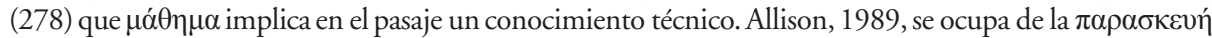
(«preparación», "preparativo») y la falta de la misma, así como de su relación con el poder.

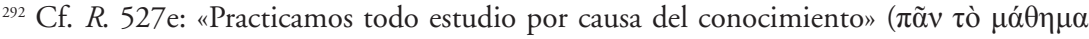

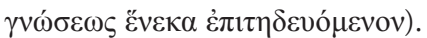

${ }^{293}$ Cf. pasaje recogido en nota 219. 
Recordemos lo indicado en Heródoto ${ }^{295}$ sobre este verbo. Nos limitaremos a los ejemplos tucidideos que tienen que ver con el campo de la educación.

17.1. En el 433 a. C., dos años después de la Batalla de Leucimna, tuvo lugar en Atenas, ante la Asamblea, una reunión extraordinaria en que participaron los corcirenses y los corintios, deseosos ambos de ganarse el apoyo ateniense. En tal ocasión los corintios instan a que los jóvenes atenienses aprendan de boca de sus mayores una serie de sucesos, anteriormente expuestos en su discurso ${ }^{296}$ : «Reflexionando sobre esos hechos, y también cualquiera bastante joven, tras haberlos aprendido de alguien de más edad, crea justo defendernos en igualdad de condiciones, y que no piense que estas palabras se exponen como justas, pero las convenientes,

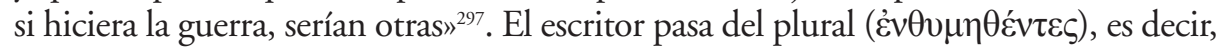
los atenienses de cierta edad presentes en la reunión, a referirse de modo especial a cada joven, en singular ( $\mu \alpha \theta \omega ́ v)$, y este número atrae, a continuación, la persona verbal. Con todo, las acciones verbales siguientes («crea justo...y que no piense») hay que referirlas a todos los atenienses que están escuchando. En realidad, hasta este momento, el discurso se venía dirigiendo a un «vosotros», es decir, todos los atenienses que forman parte de la Asamblea y que, al final del encuentro, tomaron la resolución de concertar con los corcirenses un pacto de defensa mutua en caso de sufrir un ataque de cualquier otro. Lo importante de este contexto, según nos parece, es la noción de que un joven aprenda de boca de los de más edad ${ }^{298}$.

17.2. En el tercer año de la guerra peloponesiaca (429 a. C.), tras la batalla naval de Río, los jefes peloponesios dirigieron la palabra a los suyos para que no se

${ }^{294}$ El TLG cuenta 16 ejemplos, pues comete el error de contar $\mu \alpha \dot{\theta} \theta \eta \sigma ı \varsigma$ entre las formas verbales. Huart recoge el término varias veces en su estudio sobre el vocabulario de carácter psicológico: 127, 196, 223, 278, 288, 323, 354; en 278, lo examina en correspondencia con $\delta 1 \delta \alpha ́ \sigma \kappa \omega$, es decir, contrastando, respectivamente, los valores de «aprender» y «enseñar».

${ }^{295}$ Véase Heródoto, apartado 15.

${ }^{296}$ En 1.41 los corintios aluden a dos hechos singulares en los que habrían beneficiado a Atenas: a saber, cuando ésta, con escasez de naves de guerra, luchaba contra Egina, lo que sucedió poco antes del enfrentamiento de los griegos contra los persas en Maratón (490 a. C.: cf. Hornblower: I, 85), y cuando los atenienses tuvieron que acabar con la revuelta de Samos (acaecida en el 440 a. C.). De los primeros acontecimientos, ocurridos 57 años antes, habría pocos atenienses, presentes en la Asamblea, que los recordaran por haberlos presenciado u oído de otros.

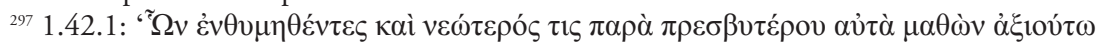

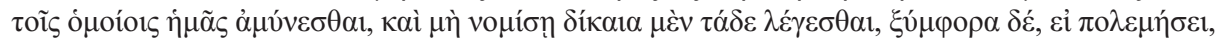

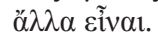

${ }^{298} \mathrm{La}$ construcción del verbo que revisamos con $\pi \alpha \rho \alpha ́$ más genitivo (indicador de la persona de quien se recibe la enseñanza o la información) la tenemos registrada desde Esquilo ( $A$. 858; Supp. 361) y Heródoto (1.107.1; 131.2; etc.). 
dejaran dominar por el miedo que les había sobrevenido después de la derrota ante los atenienses: «El saber de éstos, lo que más teméis, si contiene la valentía, también mantendrá en el peligro el recuerdo de llevar a cabo lo que aprendió; sin ánimo esforzado ninguna arte tiene fuerza ante los peligros, pues el miedo perturba el recuerdo, y el arte sin fuerza no sirve de nada ${ }^{299}$. Unas pocas notas de sintaxis aportarán quizá alguna luz a entender mejor el texto. Efectivamente el participio apositivo ỏv $\delta \rho \varepsilon i ́ \alpha v$

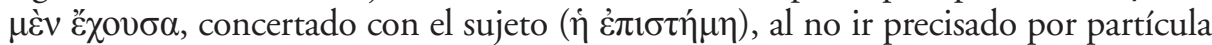
alguna, modifica el sentido de la acción verbal con un matiz impreciso (por ejemplo, temporal: «al contener»; causal, «por contener»; condicional, «si contiene»; etc.); a su

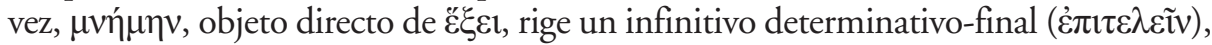
el cual lleva su objeto directo $(\ddot{\alpha} \ddot{\varepsilon} \mu \alpha \theta \varepsilon v)$ y una precisión temporal ( $\dot{\varepsilon} v \tau \tilde{\varphi} \delta \varepsilon เ v \tilde{\omega})$. Lo que nos parece claro es que el término $\dot{\varepsilon} \pi \imath \tau \eta \eta j \mu \eta^{300}$ funciona aquí como el resultado de haber adquirido un saber, la ciencia naval, en la que los peloponesios eran

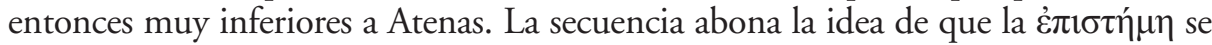
corresponde estrechamente con $\ddot{\varepsilon} \mu \alpha \theta \varepsilon v$, lo que justificaría nuestra idea de que este verbo funciona aquí dentro de los valores propios de la pareja educación-aprendizaje. Por otro lado, en el plano literario griego, es la primera vez que aparecen en contextos

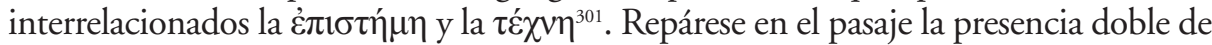

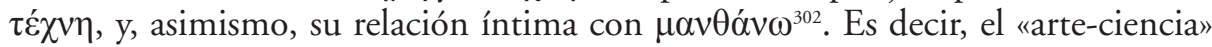
se adquiere mediante el estudio, el esfuerzo; no se trata de una simple repetición ( $\dot{\varepsilon} \mu \pi \varepsilon i \rho i ́ \alpha)$, ni de un don divino, sino de un conocimiento humano, racional.

18. $\pi \rho \mu_{\alpha} \alpha \theta \alpha ́ v \omega(1)$, «aprender de antemano», «con anterioridad».

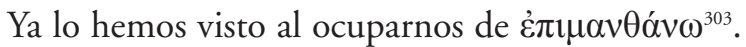

RECIBIDO: octubre 2018; ACEPTADO: octubre 2018.

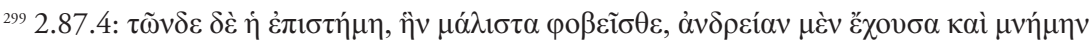

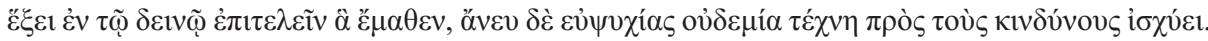

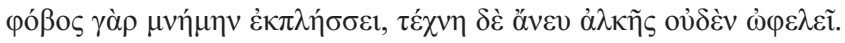

${ }^{300}$ Concepto esencial en las distintas $\tau \dot{\varepsilon} \chi \nu \alpha 1$ (artes con fundamentos racionales; ciencias podríamos decir sin exagerar) que surgen en el siglo V: medicina, retórica, matemática, pintura, cocina, etc. Lo hallamos en poesía (Sófocles, 3; Baquílides 1; Eurípides, 1; etc.) y prosa (Demócrito 1; Tucídides 14; Lisias, 1; Tratados hipocráticos 8, pero 4 en las Cartas, escritos muy tardíos; etc.). En esa centuria, Tucídides es quien más ejemplos ofrece. En el IV sobresalen Jenofonte (28), Isócrates (25), Platón (649) y Aristóteles (980). Con respecto a la relación «arte»-«historia», cf. Sommer, 2006.

${ }^{301}$ Sobre la aparición de estos dos términos en contextos próximos, véase Isócrates (11.17; 12.29.30; 15.30), Platón (Tht. 146c, 147b, 184b; etc.).

${ }^{302}$ Sólo existe el precedente de Heródoto, 2.167.1. La tenemos asimismo en Aristófanes, Pl. 905; Jenofonte, Mem.4.2.5; Oec. 15.10; Platón, Prt. 328a; Euthd. 289c; etc.

${ }^{303}$ Véase el texto recogido en nota 289. 


\section{BIBLIOGRAFÍA ${ }^{304}$}

\section{Heródoto}

\section{TeXTO SEguido.}

Herodoti Historiae (2015): ed. WILSON, N. G., I-II, Oxford University Press, Oxford (Recogida por el TLG, en línea).

\section{COMENTARios.}

Asheri, D.-Lloyd, A.-Corcella, A. (eds.) (2007): A Commentary on Herodotus, Books 1-4, Oxford University Press, Oxford.

How, W. W.-WelLs, J. (1928²): A commentary on Herodotus with introduction and appendixes, I-II, Clarendon Press, Oxford (Mis citas siguen la paginación recogida en internet, dentro del Project Gutenberg, de uso libre).

MaCAN, R. W. (1895): Herodotus. The fourth, fifth and sixth books with introduction, notes, appendices, indices, maps, I-II, Macmillan, Nueva York (Sigo la vertida en internet, de uso libre). (I abarca los libros IV, V y VI, con introducción, texto y notas; II se ocupa de esos mismos libros en lo referente a apéndices, índices y mapas. En nuestras citas, respectivamente, Macan I y II).

MaCAN, R. W. (1908): Herodotus. The seventh, eighth and ninth books with introduction, text, apparatus, commentary, appendices, indices, maps, I-II, Macmillan, Nueva York (Consulto la existente en internet, de uso libre). (I expone el libro VII, con introducción, texto y notas; II contiene los libros VIII y IX, con la misma distribución. En nuestras citas, Macan III y IV, corresponden, respectivamente a los volúmenes I y II).

SAYCE, A. H. (1883): The ancient empires of the East. Herodotus I-III, Macmillan, Londres (Me atengo a la ofrecida en internet, de uso libre).

SCOTT, L. (2005): Historical commentary on Herodotus, Book 6, Brill, Leiden-Boston-Colonia.

\section{TRADUCCIÓN.}

Heródoto. Historia (1977-1989): trad., not., SCHRADER, C., I-VIII, Biblioteca clásica Gredos, Madrid.

\section{EsTudios.}

ALY, W. $\left(1969^{2}\right)$ : Volksmärchen, Sage und Novelle bei Herodot und seinen Zeitgenossen. Eine Untersuchung über die volkstümlichen Elemente der altgriechischen Prosaerzählung, Vandenhoeck-Ruprecht, Gotinga.

Bakker, E. J.-De Jong, I. J. F.-van Wees, H. (eds.) (2002): Brill's Companion to Herodotus, Brill, Leiden-Boston-Colonia.

BAKKER, E. J., (2006): «The syntax of historie: How Herodotus writes», en DEWALD-MARINCOLA (eds.), pp. $92-102$.

\section{nuestro objetivo.}

${ }^{304}$ De la enorme bibliografía sobre Heródoto y Tucídides recojo la esencial, en relación con 
Baragwanath, E.-DE BAKKeR, M. (eds.) (2012): Myth, truth and narrative in Herodotus, Oxford University Press, Oxford.

Benardete, S. (1969): Herodotean Inquiries, M. Nijhoff, La Haya.

BiCHLER, R. (2000): Herodots Welt: der Aufbau der Historie am Bild der fremden Länder und Völker, ihrer Zivilisation und ihrer Geschichte, Akademie Verlag, Berlín.

BLOK, J. (2000): «Women in Herodotus' Histories, en BAKKER-DE JONG-VAN WeEs (eds.), pp. 225-244.

BLÖSEL, W. (2004): Themistokles bei Herodot: Spiegel Athens im fünften Jahrhundert. Studien zur Geschichte und historiographischen Konstruktion des griechischen Freiheitskampfes 480 v. Chr., Steiner, Stuttgart.

BorNITZ, H.-F. (1968): Herodot-Studien; Beiträge zum Verständnis der Einheit des Geschichtswerks, De Gruyter, Berlín.

BowIE, E. (ed.), (2018): Herodotus. Narrator, scientist, historian, De Gruyter, Berlín-Boston.

BurKeRT, W. (1990): «Herodot als Historiker fremder Religionen», en NENCI-REvERDiN (eds.), pp. 1-32.

CAmpos Daroca, J. (1992): Experiencias del lenguaje en las «Historias» de Heródoto, Instituto de Estudios Almerienses, Almería.

Derow, P.-Parker, R. (eds.) (2003): Herodotus and his World: Essays from a Conference in Memory of George Forrest, Oxford University Press, Oxford.

Dewald, C.-Marincola, J. (eds.) (2006): The Cambridge Companion to Herodotus, Cambridge University Press, Cambridge.

Dinle, A. (1962): «Herodot und die Sophistik», Philologus 106: 207-20.

DIK, H. (1995): Word Order in Ancient Greek: A Pragmatic Account of Word Order variation in Herodotus, Amsterdam Studies in Classical Philology, Amsterdam.

Foster, E.-LateIner, D. (eds.) (2012): Thucydides and Herodotus, Oxford University Press, OxfordNueva York.

Goldscheider, K. (1965): Die Darstellung des Themistokles bei Herodot (Tesis), Friburgo de Brisgovia.

GraY, V. J. (2012): «Herodotus on Melampus», en BARAGWANATH-DE BAKKer (eds.), pp. 167-194.

GRONINGEN, B. A. vAN (1958): La composition littéraire archä̈que grecque, N. V. Noord-Hollandische Uitgevers Maatschappij, Amsterdam.

Harrison, Th. (2000): Divinity and history: the religion of Herodotus, Clarendon Press, Oxford.

Harrison, Th.-IrWIN, E. (eds.) (2018): Interpreting Herodotus, Oxford University Press, Oxford.

HARTOG, F. (1988): The mirror of Herodotus: The representation of the other in the writing of history, University of California Press, Berkeley.

HazeWIndus, M. W. (2004): When Women Interfere: Studies in the Role of Women in Herodotus' Histories, Brill, Amsterdam.

Hollmann, A. (2011): The master of signs: signs and the interpretation of signs in Herodotus" "Histories», Center for Hellenic Studies, Harvard University.

Hunter, V. (1982): Past and process in Herodotus and Thucydides, Princeton University Press, Princeton.

IMMERWAHR, H. R. (1967): Form and thought in Herodotus, The Press of Western Reserve University for the American Philological Association, Cleveland (Ohio).

LATEIneR, D. (1989): The historical method of Herodotus, University of Toronto Press, Toronto.

Luraghi, N. (ed.) (2007): The Historian's Craft in the Age of Herodotus, Oxford University Press, Oxford.

LuRAGHI, N. (2013): «The stories before the Histories. Folktale and traditional narrative in Herodotus», en Munson (ed.), pp. 87-112. 
Moles, J. L. (1993): «Truth and Untruth in Herodotus and Thucydides», en GiLl, CH.-WiSEMAN, T. P. (eds.), Lies and Fiction in the Ancient World, University of Exeter Press, Exeter, pp. 88-121.

MARG, W. (ed.) (1965): Herodot. Eine Auswahl aus der neueren Forschung, Wege der Forschung, Múnich.

Munson, R. V. (2005): Black Doves Speak: Herodotus and the Languages of Barbarians, Harvard University Press, Cambridge MA.

Munson, R. V. (ed.) (2013): Herodotus (Volume 1). Herodotus and the Narrative of the Past, Oxford University Press, Oxford.

Murray, O. (2007): «Herodotus and Oral History» (el trabajo original es de 1987) y «Herodotus and Oral History Reconsidered», en LuRAGHI, N. (ed.), pp. 16-44 y 314-325.

Nenci, G.-Reverdin, O. (eds.) (1990): Hérodote et les peuples non grecs. Neuf exposés suivis de discussions (22-26 août 1988), Fondation Hardt, Vandœuvres-Ginebra.

Pavlopoulou, A. (2006): Thrakien Bei Herodot: Darstellung Einer Zwischenwelt. Studien Zur Herodots Geschichte, Geographie und Ethnographie Trakiens (Tesis), Ludwig-Maximilians-Universität, Múnich.

Rosén, H. B. (1962): Eine Laut- und Formenlehre der Herodotischen Sprachform, Carl Winter, Heidelberg.

SCARDINO, C. (2007): Gestaltung und Funktion der Reden bei Herodot und Thukydides, De Gruyter, Berlín.

SCHrader, C. (1988): «Heródoto», en López Férez, J. A. (ed.), Historia de la literatura griega, Cátedra, Madrid, pp. 503-536.

Schubert, CH. (2010): Anacharsis der Weise: Nomade, Skythe, Grieche, Gunter Narr Verlag, Tubinga (Leipziger Studien zur klassischen Philologie, 7).

SLINGS, S. R. (2002): "Oral Strategies in the Language of Herodotus», en BAKKER-DE JONG-VAN WEES (eds.), pp. 53-77.

Sourvinou-Inwood, CH. (2003): «Herodotos (and others) on Pelasgians: some perceptions of ethnicity», en Derow, P.-PARKer (eds.), pp. 113-143.

Thomas, R. (2000): Herodotus in context: ethnography, science and the art of persuasion, Cambridge University Press, Cambridge.

UbSDELL, S. (1983): Herodotus on Human Nature (Tesis), University of Oxford, Oxford.

VAndiver, E. (1991): Heroes in Herodotus. The interaction of Myth and History, P. Lang, Fráncfort del Meno.

Wesselmann, K. (2011): Mythische Erzählstrukturen in Herodots "Historien», De Gruyter, Berlín-Boston.

WeST, S. (1985): «Herodotus' Epigraphical Interests», CQ 35: 278-305.

West, S. (2002): «Scythians», en BAKKER-DE JONG-VAN WeEs (eds.), pp. 437-456.

WILL, W. (2015): Herodot und Thukydides: die Geburt der Geschichte, C. H. Beck, Múnich.

ZALI, V. (2009): Reshaping Herodotean rhetoric: a study of the speeches in Herodotus' Histories with special attention to books 5-9 (Tesis), University College, Londres.

\section{TUCÍDIDES}

\section{EDICIÓN SEGUIDA.}

Thucydidis historiae (enmend. y reimp. 1942. 1900'): eds. JONES, H. S.-POWELL, J. E., I-II, Clarendon Press Oxford (La ofrece también el TLG). 


\section{COMENTARios.}

Gomme, A. W. (1945-1981): A historical commentary on Thucydides, I-III; GOMME, A. W.-ANDREWES, A.Dover, K. J., IV-V, Clarendon Press, Oxford.

Hornblower, S. (1991-2008): A commentary on Thucydides, I-III, Oxford University Press, Oxford. Thucydides (reimp.1977; 1862¹): eds., com., Classen, J.-STEUP, J., I-VIII, Weidmann, Berlín.

\section{EsCOLIOS.}

Hude, K. (1927): Scholia in Thucydidem ad optimos codices collata, Teubner, Leipzig (Ahora en internet y $T L G$ ).

\section{TRAdUCCiOnes (ALgUnAS ACOMPAÑAN A La EDICIÓN PERTINENTE).}

The history of the Grecian war written by Thucydides (1843; 1629'): transl. HoBBES, TH., John Bohn, Londres (Ahora en internet).

Thucydide. La guerre du Péloponèse (1962-1972): ed., trad., not., RomiLLY, J. DE, I-VIII, Les Belles Lettres, París.

Thucydides (1881): transl. into English, with introd., marginal analysis, not., and indices, JOWETT, B., Clarendon Press, Oxford (ahora en internet).

Thucydides. History II (1988): ed., trad., com. Rhodes, P. J., Aris \& Phillips, Warminster (=Rhodes II).

Thucydides. History III (1994): ed., trad., com. RHODES, P. J., Aris \& Phillips, Warminster (=Rhodes III).

Tucídides. Historia de la Guerra del Peloponeso (1952): introd., trad., not., RODRíGUEZ AdRADOS, F., I-III, Biblioteca Clásica Hernando, Madrid.

Tucídides. Historia de la Guerra del Peloponeso (1990-1992): introd., trad., not., Torres EsBarRANCH, J. J., I-IV, Biblioteca Clásica Gredos, Madrid.

\section{Estudios.}

Allison, J. W. (1989): Power and preparedness in Thucydides, Johns Hopkins University, Baltimore.

Alsina Clota, J. (1981): Tucídides, historia, ética y política, Rialp, Madrid.

Balot, R. K.-Forsdyke, S.-Foster, E. (eds.) (2017): The Oxford Handbook of Thucydides, Oxford University Press, Oxford.

Cogan, M. (1981): The human thing: the speeches and principles of Thucydides' history, University of Chicago Press, Chicago.

Connor, W. R. (1985): Thucydides, Princeton University Press, Princeton.

DelebeCQue, E. (1965): Thucydide et Alcibiade, Faculté des Lettres d'Aix-en-Provence, Aix-en-Provence.

Dover, K. J. (1979): Thucydides, Clarendon Press, Oxford.

DreXler, H. (1976): Thukydides-Studien, Georg Olms, Hildesheim.

ERBSE, H. (1989): Thukydides Interpretationen, De Gruyter, Berlín-Nueva York.

Flashar, H. (1969): Der Epitaphios des Perikles. Seine Funktion im Geschichtswerk des Thukydides, Carl Winter, Heidelberg.

FORDE, S. (1989): The ambition to rule: Alcibiades and the politics of imperialism in Thucydides, Cornell University Press, Ithaca (Nueva York)-Londres. 
FRIEDRICHS, J. (2000): Aufschlussreiche Rhetorik: ein Versuch über die Redekultur und ihren Verfall bei Thukydides, Ergon, Würzburg.

Gommel, J. (1966): Rhetorisches Argumentieren bei Thukydides, Georg Olms, Hildesheim.

Hagmaier, M. (2008): Rhetorik und Geschichte: eine Studie zu den Kriegsreden im ersten Buch des Thucydides, De Gruyter, Berlín-Nueva York.

HeITsCh, E. (2007): Geschichte und Personen bei Thukydides: eine Interpretation des achten Buches, De Gruyter, Berlín-Nueva York.

Herter, H. (ed) (1968): Thukydides, Wissenschaftliche Buchgesellschaft, Darmstadt.

Hornblower, S. (1987): Thucydides, Duckworth, Londres.

HoRnblower, S. (2004): Thucydides and Pindar: historical narrative and the world of epinikian poetry, Oxford University Press, Oxford.

HUART, P. (1968): Le vocabulaire de l'analyse psychologique dans l'oeuvre de Thucydide, Klincksieck, París. JunG, V. (1991): Thukydides und die Dichtung, Lang, Fráncfort del Meno.

KaKRIDIS, J. TH. (1961): Der Thukydideische Epitaphios: ein stilistischer Kommentar, Beck, Múnich.

KALLET, L. (2001): Money and the corrosion of power in Thucydides. The Sicilian expedition and its aftermath, University of California Press, Berkeley-Los Angeles.

López Férez, J. A. (1988): «Tucídides», en López Férez, J. A. (ed.), Historia de la literatura griega, Madrid, Cátedra, pp. 537-567.

OrWIN, C. (1994): The humanity of Thucydides, Princeton University Press, Princeton.

ParrY, A. M. (1981): Logos and Ergon in Thucydides, con nueva introducción de Kagan, D., Arno Press, Nueva York (Tesis, Harvard, 1957).

Plant, I. (2015): «Thucydides, Timotheus and the Epitaph for Euripides», The Classical Journal. 110.4: 385-396.

Pontier, P. (2013): «The litotes of Thucydides», en Tsakmakis-TAmiolaki (eds.), pp. 353-370.

Pothou, V. (2009): La place et le rôle de la digression dans l'oeuvre de Thucydide, Franz Steiner, Stuttgart.

Price, J. J. (2001): Thucydides and internal war, Cambridge University Press, Cambridge.

Proctor, D. (1980): The experience of Thucydides, Aris \& Phillips, Warminster.

RAMÓN PALERM, V. (1996): Estudios sobre Tucídides: ensayo de un repertorio bibliográfico (1973-1995), Universidad de Zaragoza, Zaragoza.

RaWLINGS, H. R. (III) (1981): The structure of Thucydides History, Princeton University Press, Princeton.

ReCHENAUER, G. (1991): Thukydides und die hippokratische Medizin: Naturwissenschaftliche Methodik als Modell für Geschichtsdeutung, Georg Olms, Hildesheim.

ReCHENAUER, G.-POTHOU, V. (eds.) (2011): Thucydides, a violent teacher?: history and its representations, V\&R unipress, Gotinga.

Ros, J. G. A. (1968): Die metabole (variatio) als Stilprinzip des Thukydides, Hakkert, Amsterdam.

SOMmer, K. I. L. (2006): Techne und Geschichte: eine diskursgeschichtliche Studie zu Thukydides, Habelt, Bonn.

Tsakmakis, A.-TAmiolaki, M. (eds.) (2013): Thucydides Between History and Literature, De Gruyter, Berlín-Nueva York.

WeIDAuer, K. (1954): Thukydides und die Hippokratischen Schriften: der Einfluss der Medizin auf Zielsetzung und Darstellungsweise des Geschichtswerks, Winter, Heidelberg. 
WiLSON, J. B. (1987): Athens and Corcyra: strategy and tactics in the Peloponnesian War, Bristol Classical Press, Bristol.

Ziolkowski, J. E. (1981): Thucydides and the tradition of funeral speeches at Athens, Arno Press, Nueva York.

\section{BiBLIOGRAFÍA AUXILIAR}

\section{INSTRUMENTOS GENERALES.}

Bailly, A. $\left(1965^{26}\right)$ : Dictionnaire grec-français, rev. SÉCHAN, L.- Chantraine, P., Hachette, París.

Chantraine, P. (1968): Dictionnaire étymologique de la langue grecque. Histoire des mots, Klincksieck, París.

Hippocrate. Des vents. De l'art (1988): ed., trad., com., Jounnna, J., Les Belles Lettres, París.

$D G E=$ Diccionario Griego-Español (1980 ss.): AdRADOS, F. R. et alii, CSIC, Madrid (Ahora, en línea).

LSJ (= A Greek-English Lexicon) (reimp. 1973=1940'; 1843'): LidDELL, H. G.-SCOTT, R.-rev. JONES, H. S. et alii, Clarendon Press, Oxford.

LASSO de LA VeGa, J. S. (1968): Sintaxis griega, I, CSIC, Madrid.

SCHWYZER, E. (1968'; 1953'): Griechische Grammatik. I. Allgemeiner Teil. Lautlehre. Wortbildung. Flexion, Beck, Múnich.

TLG (= Thesaurus Linguae Graecae) (2001): University of California. Irvine (California) (en línea).

\section{Estudios.}

Christ, M. R. (1989): «The Authenticity of Thucydides 3.84», Transactions of the American Philological Association 119: 137-148.

Cohen, E. (2000): The Athenian Nation, Princeton University Press, Princeton.

Coray, M. (1993): Wissen und Erkennen bei Sophocles, Friedrich Reinhardt, Basilea.

CraiK, E. M. (2015): The 'Hippocratic' Corpus: Content and Context, Routledge, Londres-Nueva York.

DÖRRIE, H. (1956): Leid und Erfahrung. Die Wort-und Sinn-Verbindung $\pi \alpha \theta \varepsilon \tilde{i} v-\mu \alpha \theta \varepsilon \tilde{v} v$ im griechischen Denken, Steiner, Wiesbaden.

Douterelo FernÁndeZ, E. (2001): El vocabulario del conocimiento en la obra de Esquilo (Tesis), Universidad Complutense, Madrid (accesible en internet).

Dover, K. J. (1974): Greek popular morality in the time of Plato and Aristotle, Blackwell, Oxford.

Francis, E. D. (1991-1993): «Brachylogia Laconica: Spartan Speeches in Thucydides», Bulletin of the Institute of Classical Studies 38: 198-212.

Gagarin, M. (2003): «Letters of de Law: written Texts in archaic Greece», en YunIS, H. (ed.), Written Texts and the rise of Literate Culture in Ancient Grece, Cambridge University Press, Cambridge, pp. 59-77.

Halm-Tisserant, M. (1983): Cannibalisme et immortalité. L'enfant dans le chaudron en Grèce ancienne, Les Belles Lettres, París.

JouAnna, J. (1992): Hippocrate, Fayard, París.

Kennedy, G. A. (1963): The art of persuasion in Greece, Princeton University Press, Princeton.

LAPE, S. (2010): Race and Citizen Identity in the Classical Athenian Democracy, Cambridge University Press, Cambridge. 
López Férez, J. A. (1995): «El tema de la educación en Eurípides», en Primeras Jornadas Internacionales de teatro griego, Universidad de Valencia, pp. 209-233.

López Férez, J. A. (1997a): «La educación en Aristófanes», en López EIre, A. (ed.), Sociedad, política y literatura. Comedia griega antigua, Logo, Salamanca, pp. 81-101.

LÓPEZ FÉrEZ, J. A. (1997b): «Estudio léxico del campo de la educación en Platón», en ADRADOS, F. R.Martínez Díez, A. (eds.), Actas IX Congreso Español de Estudios Clásicos, Sociedad Española de Estudios Clásicos- Ediciones Clásicas, Madrid, I, pp. 137-142.

LÓPEz Férez, J. A. (2000a): «El léxico de la educación en Platón», en GonZÁlez de TobiA, A. M. (ed.), Una nueva visión de la cultura griega antigua en el fin del milenio, Editorial de la Universidad Nacional de La Plata, Universidad de La Plata, pp. 287-305.

LÓpez FéreZ, J. A. (2000b): «Observaciones sobre el léxico de la educación en Platón», en LÓPEZ Férez, J. A. (ed.), La lengua científica griega: orígenes, desarrollo e influencia en las lenguas modernas europeas. II (Los compuestos de pous-Aristófanes-Platón-Comedia postaristofánica-Interferencias del griego y el latín-Ortega y Gasset), Ediciones clásicas, Madrid, pp. 61-121.

López Férez, J. A. (2000c): «El léxico de la educación en Heródoto y Tucídides», en CRESPO, E.Barrios Castro, M. J. (eds.), Actas X Congreso Español de Estudios Clásicos (Universidad de Alcalá. 21-25/09/1999), Sociedad Española de Estudios Clásicos, Madrid, I, pp. 203-210.

López Férez, J. A. (2002): «El léxico de la educación en los tratados hipocráticos», en THIVEL. A.ZUCKER, A. (eds.), Le normal et le pathologique dans la Collection hippocratique (X' Colloque international hippocratique. Université de Nice. Faculté des Lettres. 06-08/10/1999), Université de Nice-Sophia Antipolis, 313-357 (Apareció también en Synthesis 7, 2000, pp. 9-55).

LÓpez Férez, J. A. (2003): «Notas sobre el léxico de la educación en Galeno. I», en GarzYA, A.Jounnna, J. (eds.), Trasmissione e ecdotica dei testi medici greci (Atti del IV Convegno internazionale. Les textes médicaux grecs. Université de Paris IV-Sorbonne. 17-19/05/2001), D’Auria, Nápoles, pp. 281-319.

LÓpez FÉrez, J. A. (2004): «Notas sobre el léxico de la educación en Aristóteles», en López Férez, J. A. (ed.), La lengua científica: Orígenes, desarrollo e influencia en las lenguas modernas europeas. III. Aeido-aoidós en los poemas homéricos-Seres intermedios de la filosofía griega-Léxico de la educación en Aristóteles-Constitución del vocabulario médico en griego antiguo-Téchne y derivados en la comedia griega-Léxico de Menandro sobre el aticismo-Léxico esfigmico desde el griego hasta nuestros dias-Desde el griego hasta el latin: las siete Artes liberales, Ediciones Clásicas, Madrid, pp. 53-153.

López Férez, J. A. (2015): «Algunos términos retóricos en Galeno», en López Férez, J. A. (ed.), Galeno. Lengua, composición literaria, léxico, estilo, Ediciones clásicas, Madrid, pp. 245-274.

López Férez, J. A. (2016): «El léxico de la educación en Sinesio», en CRIscuOlo U.-LozZA, G. (eds.), Sinesio di Cirene nella cultura tardo-antica (Atti del Convegno Internazionale. Napoli 19-20 giugno 2014), Ledizioni, Milán, pp. 47-83.

Macleod, C. W. (1979): «Thucydides on faction (3.82-83)», Proceedings of the Cambridge Philological Society 205: 52-68.

MeIGGS, R.-LewIS, D. (eds.) (1988²): A selection of Greek Historical Inscriptions to the end of the Fifth Century B.C., Oxford University Press, Oxford.

ScHмITT, R. (ed.) (1989): Compendium Linguarum Iranicarum, Dr. Ludwig Reichert Verlag, Wiesbaden.

Sunshine, E. R. (1964): The Meaning of Physis in Aeschylus, Sophocles, and Euripides, (Tesis), Loyola University, Chicago. 